PD01-1

QOL 評価ツールの選択と開発に関する検討

慈恵医大第三病院 臨床検査医学1), 佐久市立国保浅間総合病 院外科 ${ }^{2)}$, 横浜市立市民病院消化器外科 3 , 金沢医科大学消化 器外科治療学 4 , 国際医療福祉大学病院外科(5), 慈愛会今村病 院外科 6), 静岡県立静岡がんセンター胃外科 (7), 名古屋大学消 化器外科8). 一胃癌術後評価を考える」ワーキンググループ9) 中田浩二 ${ }^{1.99}$, 池田正視2.9), 高橋正純 3.99 , 木南伸一4,9), 吉田昌 ${ }^{5.9}$, 上之園芳一6.9), 寺島雅典 ${ }^{7.99}$, 小寺泰弘 ${ }^{8.9}$ )

術式や薬物治療の有効性を評価する上で患者の視占からみた医療 評価(PRO) は重要である。米国FDA は信頼性と妥当性が検証 された適切なPROの使用を推奨し、それがない場合には目的に適 う新たなPROの策定を提案している。QOL評価には全般的尺度 と特異的尺度の併用が必要とされる。全般的尺度は複数開発され ており、汎用性があるためさまざまな疾患や治療の評価に用いら れるが、疾病や治療法の違いや変化を拾い上げる感度は低いこと が知られている。特望的尺度は疾病や治療法の違心を鋭敏に拾い 上げることができるが、数多くある疾患や治療法に適したPROの 開発は十分ではなく、他の目的で開発された特異的尺度を代用し たりオリジナルの検証されていない質問票を使用するなどが行わ れているこのため, 適切な $\mathrm{PRO}$ 面いた科学的な評価は今後に 残された課題である。目まぐるしく変わる医療ニーズに対応夺る ためには、適宜新しい特異的尺度を策定する必要がある。その際 には臨床医が重要と考える評価項目の抽出・重み付け・コシセン サスによる絞り込みを効率的に進めてゆく必要がある。また単に 評価するだけでなく、その結果を日常の診療に活かすための工夫 も必要である。演者らが策定に関わったPGSAS-45（胃切除後障 害)、GERD-TEST (胃食道逆流症・機能性ディスペプシア予)、

PD01-2 乙効果量

的重要性、そして効果量

東京女子医科大学 乳腺・内分泌外科、衛生学公衆衛生学 岡本高宏

QOLを含む患者の主観Patient-reported outcomes(PROs) を

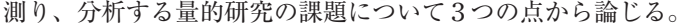
【心理計量学と臨床測定学】PROsを“正しく測る”ためには測 定用具の性能を確認することが不可欠である。健康科学におけ 万測定論がその基礎を置く心理計量学では用具の信頼性 (再現 性、内部一貫性) と妥当性（基準妥当性、概念妥当性）を統計 学的に検証することが強調されてきた。一方、そうした統計学 的要請よりも表面妥当性、内容妥当性、そして測定の平易さを 重視するのが臨床測定学である。

【統計学的有意性と臨床的重要性】群間比較や群内比較で認め た差の統計学的有意性だけでなく、その差が臨床的にどのよう な意味を持つかを明らかにしておくことが大切である。これは 研究設計の段階でサンプルサイズを合理的に設定するうえでも 重要である。

【エビデンスとしての効果量】同じ疾患を対象としても、ある いは同じPROsをアウトカムとしていても測定に使われる用具 は研究によって異なることが稀ではなく、研究結果の比較や解 釈あるいは統合が容易でない。これを解消するには効果量で示 すことである。効果量にはCohen's $d$, Hedges' $g$, そしてGlass's カがあり、どれを用いるかは研究デザインやアウトカムデータ の等分散性による。効果量は臨床的重要性を解釈するうえでも 有用である。

PD01-3 外科手術、特に消化管がん術後の QOL 評価 川崎医科大学 消化器外科 藤原由規, 東田正陽, 維田寿子, 岡本由佑子, 峯田修明, 上野綸, 渡邊裕策, 岡田敏正, 岩本怜, 北川集士，木下征也，鶴田淳， 上野富雄

QOL とは、個人の満足度、幸福度などを図る指標であるが、 広義には、心身の健康だけでなく社会的な二面も考慮す心゙きで あると考えられている。がん患者用のQOLの包括的評価とし てFACTの指標がある。これは、FACT-Gという一般的な指 標だけでなく、各種癌腫（乳がん、肺がん、大腸がんなど）に 加えて緩和用、貧血用などが用意されているがその信賴性、妥 当性に関しては疑問的な意見も多い。EORTC QLQ-C30も同 様に癌患者用のQOL尺度である。一方、QOL評価は治療対象 の臓器特異性についても検討する必要性がある。とくに私の専 門としている消化管外科の領域においては、評価の目的により さまざまな評価シートが存在する。上部消化管術後の QOL評 価スケールとして、GSRS(Gastrointestinal Symptom Rating Score）がしばしば使用されるが、SF-12スコアと相関性がみ られないためにその妥当性が疑問視されている。消化管症状を 有する患者の QOL評価として出雲スケールも同様の質問事項 から成り立つが術後患者の QOLを評価するものではない。現 在、消化管術後のQOL の尺度評価としては有用なものは存在 しないが、がん患者 (術後含めて) 全体としてのQOL、臓器 特異的QOL 評価を組み合わせた統合的な新たな指標の確立が 望ましい。 
PD01-4

食道癌術後のQOL評価におけるEORTC OES18の日本語版作成とその妥当性の検証

国立がん研究センター東病院 食道外科1)，国立がん研究セン 多一東病院 胃外科 2

藤田武郎 ${ }^{1}$, 佐藤和磨 ${ }^{2}$, 登内晶子 ${ }^{2}$, 佐藤怜央 ${ }^{2}$, 藤原尚志 ${ }^{1}$, 海藤章郎 ${ }^{2}$, , 未下敬弘 ${ }^{2}$, , 大幸宏幸 ${ }^{1}$

【はじめに】国際的に良く知られるEORTCの食道がん患者向けの format(EORTC-OES18) は多くの言語に翻訳され各国で使用さ れてきたが、近年まで日本語版が存在しなかった。当科では EORTC 本部と連係して、2014年に日本語版 EORTC-OES18を作 成したので、作成に関するプロセスと有效性を検証したので報告 する。【方法】EORTCのガイダンスに則り、原版翻訳を、 Phasel : EORTCの翻訳ガイドラインに従つて翻訳第1版を作成 し、EORTCのコメントに従い翻訳第 2 版を作成。Phase2：上記 過程で作成の日本語版を用いて pilot testing $の$ 承認を得た。次に 被験者に対し pilot testing 䒠施し、EORTC本部との discussion にて改定と心理的評価を経てEORTC-OES18日本語版を作成し た。更にここれを当科で食道切除再建術を行った患者に連用し評 を用いて術後QOLを調查した Internal consistency解析に上る validation score は各項目で良好であった。EORTC-OES18日本語 版の収束的妥当性は高々 $(\mathrm{r}=0.671-0.903 ; \mathrm{p}<0.01)$ 、弁別的妥当性 も良好であった。胸垫鏡と開胸手術を比較した検討では術後疼痛 が胸腔 鏡群で優位に少なかった (scale value: 9.62 vs. 12.71 $\mathrm{p}=0.04$ ) 【結語】我々はEORTC-OES18日本語版を上記プロセス により作成し検証を行った。異なる文化背景にても妥当性は良好 あり、本邦でのQOL調查に有用と考えられた。

PD01-5 PGSAS37を用いた腹腔鏡下胃全摘術と腹䏶鏡 下噴門側胃切除術後のQOL

国立がん研究センター東病院 胃外科1)，国立がん研究センター 東病院 食道外科 2

龟山亭 1 , , 海藤章朗 ${ }^{1)}$ ，佐藤怜央 ${ }^{1)}$, 登内晶子 1 , 秋本瑛吾 1 ,

原田純一郎 ${ }^{1}$, 吉田弥正 ${ }^{1}$, 西口由紀子 ${ }^{1}$, 龟田千津 ${ }^{1)}$, 大幸宏幸 ${ }^{2}$, 藤田武郎 ${ }^{2)}$ ，藤原尚志 ${ }^{1,2)}$ ，木下敬弘 ${ }^{1}$

【背景】

早期胃癌の増加と治療成績の向上による長期生存者の増加により、胃癌 術後の QOL 維持は重要な課題とされている。当科で行った腹腔鏡下胃全 摘術 (LTG) / 噴門側胃切除術 (LPG) 施行後のQOL 調查の結果を報告 效象・方法】

2016年10月〜2018年 4 月に当科でLTG、LPGを施行した胃癌患者56例 (重複癌、残胃癌、術後化学療法施行例、follow up 1 年未満は除外) 対象と L, Postgastrectomy Syndrome Assessment Scale-37 (PGSAS-37) を角いて、術後の生活状況、QOL、体重減少率、栄養指標を調查した結 果を検討した。

【結果】

男女比は38：18、年齢中央值は、71歳（42-89）。術式はLPGが33例（Double-tract再建 (DT) : 23例、Double-flap 再建 (DF) : 10例)、LTG が23 例に施行された。術後1 カ月時占ではLPG-DTに比して、LPG-DF群の 食道逆流スコア (中央値) が有意に低值であった 術後 1 年時占での各術式の全体症状スコアに有意差はなく 体重減少率 (中央值) は、 LPG-DT碓) / LPG-DF群/LTG群でそれぞれ11.4/11.7 $14.7 \%$ であった $(\mathrm{P}=0.183)$

結語]

今回の研究では、各術式の術後 1 年時点での QOL に有意差はみられなか つた。症例の集積を行い、適切な術式の選択や、術後栄養介入について さらなる検討が必要であると思われた。

PD01-6 胃癌術前の健康関連包括的QOLは術後疾患特 異的QOLや骨格筋量減少と関連するか

浜田医療セン多外科

高橋節，永嶺彩奈，永井聡，渡部裕志，栗栖泰郎

【目的】健康関連 QOL尺度は集団間における QOLの比較に有 用であるが、将来における QOLや個人の状態との関連性はあ まり検討されていない。胃癌術前の包括的 QOL (SF-36v2 \&reg) が、術後半年目の疾患特異的 QOL (Pgsas-37) や骨格筋量減少 と関連性があるか検討した。【対象】：胃癌で手術をおこなった

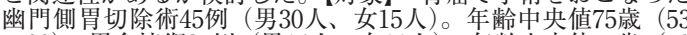
９0）。胃全摘術25例 (男14人、女11人)。年齢中央值77歳 $(50$ 〜88) 再発や浮腫を認めた症例は除外した。【方法】術前 SF$36 \mathrm{v} 2$ \&reg で3つのサマリースコア (身体的健康度: PCS、精神 的健康度:MCS、役割/社会的健康度:RCS) を算出し、年齢階 級別2007年国民標準值の第 1 四分位值で健康良群と健康悪群の 2 群に分けた。骨格筋量は術前と術後半年目にIn Body720 \& reg で測定し、骨格筋指数 (SMI) を算出した。【結果】術前 PCS はSMIの減少量と相関した。術前MCSはSMIの減少量、術後 全体症状、術後生活不満度と相関した。術前RCSは術後食事 の質と相関した。胃全摘術では役割/社会的健康悪群は術後全 体症状が多く、生活不満度が高かった。幽門側胃切除ではSF36v2 $2^{\text {reg }}$ の 3 つのサリースコアの内、2個以上で健康悪群に なると、術後全体症状が多く、SMIの減少量が多かった。【結論】 術前の健康関連包括的QOL は術後疾患特異的 QOL や骨格筋量 減少と関連性があり、これらを予測する指標になる可能性があ
PD01-7

周術期におけるエドモントン症状評価システム

有用性

大坦市民病院 外科

宇治誠人, 金岡祐次, 龟井桂太郎, 前田敦行, 高山祐一, 高橋崇真, 桐山宗泰

【目的】エドモントン症状評価システム (ESAS-r) は,緩和医 療の対象となる患者が頻繁に経験する症状の「痛み」「倦䓌感 「眠気」「哣気」「食欲不振」「息苦しさ」「気分の落ち込み」「不 安体的な調子」に「その他」を加之た10項目について 症状がない 0 から最も悪い 10 までで評価する方法である.今回 我々は消化管手術の患者にESAS-rを用い, 周術期に拉ける有 用性を検討した。【方法】2015年から2017年の間に手術を行つ た胃癌236例と大腸癌223例に対して入院時と退院前にESAS-r の評価を行った。また,術前, 退院前退院後に行った血液検查 より小野寺PNIを测定して全身状態の指標とした。【結果】 ESAS-r総計の中央值は, 入院時が $9(0-65)$ で退院前が13 ( 0 -82）だった，退院前 ESAS-r総計は在院日数が長い群で有意に 高かったが, 合併症や腹腔鏡の有無では有意差を認めなかった 胃癌と大腸癌では入院時 ESAS-r総計に有意差はないが, 退院 前では胃癌の方が有意に高く（胃癌 12 v.s. 大腸癌 $8, \mathrm{p}<0.01$ ) 項目別に検討すると, 胃癌の退院前ESAS-rにおいて嘔気と食 欲不振が大腸癌より有意に高かった。退院前 ESAS-r 総計が低 い群では退院前の小野寺PNIが有意に高く, また退院後におい ても高い傾向にあった (それぞれ $\mathrm{p}<0.01, \mathrm{P}=0.051)$ 【考察】周 術期にESAS-rを用いることで，退院時に抱えやすい問題を術 前より把握し解決することで, 全身状態の早期回復につながる 可能性があると考えられた。

PD01-8

肝切除患者における EQ-5Dを用いた健康関連

QoL評侹

国立がん研究センター東病院 肝胆膵外科

森末遼, 高橋進一郎, 杉本元一, 小林信, 後藤田直人

【背景】EuroQoL-5Dimensions (EQ-5D) は健康関連QoL (HRQoL) の包括的評価尺度の一つであり、質調整生存年を算出できること から近年注目されているが、肝切除患者に拀けるEQ-5D老用いた HRQOLに関する報告はそしいのが現状である. 【目的】肝切除患者の HRQOL の推移を $\mathrm{EQ}-5 \mathrm{D}$ を用いて明らかに

〔方法】2016年 7 月から 2017 年11月で当科において肝悪性腫瘍の診 断で根治的肝切除を予定している患者を対象とし、術前 (T1) 術後 1 週間 (T2)、1 (T3)、4 (T4) 8 (T5)，12か月後 (T6 にEQ-5Dを用いて前向きに調查し、得られた結果は換算式を用い てQoL効用值に換算した

【結果】 解析対象は 142 例（肝膵同時切除例 1 例と重複肝癌症例 1 例を除く). 年齢中央值 (範囲) $: 70(29-87)$ 歳、男/女：104/38例、 術前診断：肝細胞癌 (HCC) 41例、肝内胆管癌 (ICC) 9 例、輬 移性肝腫瘍 (MET) 75例、肝門部領域胆管癌 (BPC) 12例、胆桽 癌 (GBC) 3 例、未診断 2 例、腹胿鏡手術 92 例、胆道再建 15 例、 病理診断: HCC42例、ICC8例、混合型肝癌 1 例、MET74例、 BPC12例、GBC3例、良性腫瘍 2 例。QoL効用值の推移 $(\mathrm{T} 1 / 2 / 3$ $4 / 5 / 6$ ) は、平均で $0.863 / 0.752 / 0.806 / 0.868 / 0.862 / 0.879$ 、中央 值で $0.829 / 0.742 / 0.814 / 0.829 / 0.836 / 1.000$ であった。

【結語】肝切除患者の QoL効用値は術後 1 週間で最低、術後 4 か 月で術前水準と同等となりその後は一定して経過した。本検討は 肝切除患者における $\mathrm{EQ}-5 \mathrm{D}$ を用いた HRQOLの新たなりファレン スとなりうると考えられた。

PD01-9 術前フレイル判定は肝切除後 QOL 低下の予測 因子になりうるのか：多施設前向き研究による検討 大阪市立大学 肝胆膵外科学1 1 , 滋賀医科大学 消化器外科2) 和歌山県立医科大学第 2 外科3), 大阪医科大学一般・消化器 外科4), 奈良県立医科大学 消化器外科(5), 近畿大学 外科 6), 関西医科大学 肝臓外科 7 , , 京都府立医科大学 消化器外科 8 , $^{\text {, }}$ 大阪大学 消化器外科学 9

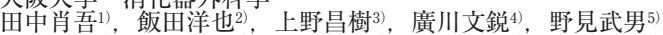

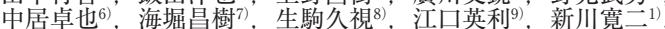
前平博充 ${ }^{2}$, , 速水晋也 ${ }^{3}$, , 久保正二

【背景・目的】高齢者に対する外科治療後には術後に療㝨目的転院や介護 䚴が要になることがある。これまでに我々は多施設前向き研究でフ 登録が終了したため、最終報告を行う。【患者・方法】対象は 9 大学病院 で肝腫瘍に対し肝切除を予定している65歳以上の自立生活を送っている 患者のうち本研究に対し同意を得大症例 (2016年 5 月〜 2018年12月)。

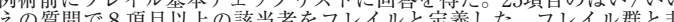
えの質問で8項目以上の該当者をフレイルと定義した。フレイル群と非 フレイル群の臨床像および術後成績を比較検討し、肝切除に対するフレ イルの影響について検討した。【結果】406例の登録のうち、107例 (26.3\% がフレイルと判定された。全体像ではフレイル群では非フレイル群に比 較して、Clavien-Dindo IIIa以上の合併症の頻度が高く、せん退院後介護申請の頻度が高陪養見 瘍因子拉よび手術関連因子を傾向スコアマッチングしたところ、片群71 例ずつ抽出された。マッチシグ後、術後合併症の頻度も2 群間で差が認 められず、退院後介護申請の頻度のみがフレイル群で高かった $(26.8 \%$ v $4.2 \% 、 \mathrm{p}<0.001)$ 。【まめ】フレイルは術後介護が必要になる頻度が高か つたが、地域包括医療を用いることで自立生活の維持は可能であると考 えられた。 
PD01-10

下部直腸癌手術後の排尿機能に対する年齢によ

る影響

東京大学 腫瘍外科

石井博章, 園田洋史, 室野浩司, 江本成伸, 金子学, 佐々木和人, 秀野泰隆，西川武司，田中敏明，畑啓介，川合一茂，野澤宏彰， 石原聡一郎

【目的】下部直腸癌手術後の排尿機能に関して、年齢による影響を 明らかにする

【方法】当科に扔いて、2013年12月から2017年 5 月までに下部直腸 癌に対して根治手術を行った症例を対象として、排尿機能を術前 および術後 1 力月、 3 力月、 6 力月、9 月、12 力月に国際前立 腺症状スコア (IPSS) を用いて調查した。IPSSのすべての項目に 回答が得られた 54 例において、若年群 (65歳未満) と高齢群 (65 歳以上) に分けて比較検討を行った (術前IPSS 13以上は除外)。

【結果】若年群33例、高齢群21例。若年群では、術前IPSS 3.3に比 べ術後 1 カ月でIPSSが有意に上昇 $(7.4, \mathrm{p}=0.0041)$ し、その後 は緩徐に低下傾向であったが、術後12 カ月ではIPSS 6.6 と依然高 值であった。高齢群では若年群に比べて、スコアの変化にそしく また術後12 力月でIPSS 3.0 と若年群より低值であった $(\mathrm{p}=0.0061)$ 項目毎に見ると、若年群は残尿感、尿意切迫感、尿勢低下、腹圧 排尿、夜間排尿回数、高齢群は残尿感で有意に増悪が見られた。 術後 12 カ月のQOLに関するスコアは若年群で有意に高值であっ た $(2.09$ vs. $0.9 、 \mathrm{p}=0.0061)$.

【結論】下部直腸癌術後において、若年者の方が排尿障害の症状が 出やすい可能性が示唆された。しかしながら両群ともに術後12 ケ 月におけるQOLのスコアは比較的低值に留まっており、下部直腸 癌術後の排㽷障害は日常生活上許容されうるものと思われた。

PD01-1

後の QOL

直腸瘤に対する transanal internal Delorme術

刍田総合病院 消化器外科

角田明良, 高橋知子, 草薙洋

背景：従来FIQL, PAC-QOLの validation studyを行ってきた (Surgery Today 2013, 2015)。目的：直腸瘤に対する transanal internal Delorme(TAD) 法術後の QOL を SF-36と PAC-QOL を用いて評価し、臨床的に有意の変化であるか検証した。方法 QOL と constipation scoring system (CSS) を術前、術後3, 6 12Mで評価した。OL scoreの変化が臨床的に有意か否かを検 証する方法として distribution-base methodsの一つである effect size(ES) を用いた。ESは<0.2でno change, $\geqq 0.2 て ゙$ small change, $\geqq 0.5$ でmoderate change, $\geqq 0.8 て ゙$ large change とされ る。結果：30例にTADが行われた。排便造影で直腸瘤は縮小 した [34 vs10mm, P <0.0001]。CSS scoreは術後3,6,12M で有 意に低下した。PAC-QOL の subscaleである Worries/concerns (WC), Physical discomfort(PH), Psychosocial discomfort(PS), Satisfactio(ST) の scoreはいずれも術後12M で有意 に低下した。scoreの変化を ESで評価すると、WCは-1.02, PH は -0.88, PSは -0.94 , ST -0.97 large changeであった。 SF-36の 8 つ subscale scoreのうち12Mで有意に上昇したの はPhysical functioning (PF), Health perception(HP), Energy, Social functioning(SF) , Role emotional(RE) の 5 つであ つた。ESで評価すると PH,0.28; HP, 0.60; Energy, 0.54; SF, 0.69; RE, 0.44と small-moderate changeであった。結論: TAD の 術後QOLはPAC-QOLで大きな改善が認められた。

PD01-12 骨盤臟器脱手術における排泄機能とQOL の評

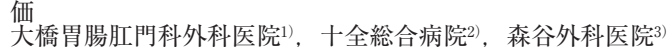
大橋勝久 ${ }^{1)}$, 佐々 木章公 ${ }^{2}$, 太田和美 ${ }^{2}$, 松尾嘉禮 ${ }^{2}$, 森谷行利 ${ }^{3}$

【はじめに】骨盤臓器脱は、臟器脱出の症状に加え排泄（排便 排尿) 機能障害を合併するため、治療にともない機能や患者の QOLがどう変化するか評価する必要がある。

【目的】骨盤蔵器脱に対する経腹的手術による排泄機能と QOL の変化を検討する。

【方法】術前および術後 3 ケ月目の排泄機能及び排泄関連 $\mathrm{QOL}$ を集計できた17症例（ICIQ - SFと J - PFDI-20に関しては 6 症例）について、術前後の変化を後方視的に評価した。

【結果】便失禁スコア (FISI) は術前後有意な変化なく $(\mathrm{p}=0.315) 、$ 便失禁QOL (JFIQL) 4 項目平均は有意に改善した $(\mathrm{p}=0.036)$ 便秘スコア (CSS) は有意に改善し $(\mathrm{p}=0.014)$ 、便秘関連 QOL （JPAC - QOL）４項目平均は有意な変化はなかった $(\mathrm{p}=0.206)$ 。 尿失禁 $\mathrm{QOL}(\mathrm{ICIQ}-\mathrm{SF})$ は有意に改善L $(\mathrm{p}=0.040)$ 、骨盤底 困躬度 (J - PFDI-20) は平均值・臟器脱障害・結腸直腸 - 肛 門障害・下部尿路機能障害いずれも有意に改善した $(\mathrm{p}=0.015$. $\mathrm{p}=0.015 \cdot \mathrm{p}=0.015 \cdot \mathrm{p}=0.015)$ 。Clavian-Dindo Grade3以上の合 併症はなかった。

【まとめ】いずれの機能スコアやQOLに関して、有意に悪化す る項目はなく、尿路機能の改善もみられ、臓器脱による困效度 は有意に改善した。骨盤臓器脱に対する経腹手術は、脱出の改 善だけでなく排泄機能の改善も期待できるため、症例に応じ積 極的に検討すべきである。常診療での排泄機能各種スコアの 評価方法や問題点も含め報告守る。
でやっていけますか? 元四ルビー株式会社く代表取締役会長兼 $\mathrm{CEO}^{1)}{ }^{1)} \mathrm{NPC}$ 松本晃 ${ }^{1}$

日本は、大学は、そして病院は90年頃までは確かにそれでうまく やっていた。しかし、平成の30年の間に何もかもうまくいかなく なってしまった。

政府の財政は破綻し、多くの病院は赤字に喘ぎ、医療従事者は疲

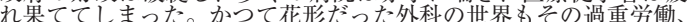
低賃金、医療過誤のリスクを嫌い若手医師から敬遠された結果、 外科医不足が深刻な問題となっている。

一方、女性外科医は少しずつではあるが増えている。しかし、そ ドはあまりにも遅い。

第二次安倍政権は発足とともに女性活躍を揭げた。そして、5年 も経ってから「働き方改革」を進めようとした。医療の世界は長 時間労働の是正と残業手当の不支給の問題のみに議論が集中し、 結局「あの大騒ぎは何だつたのだ?」ということにしかならなか つた。ただ病院の経営を苦しめたことだけは間違いない。

私は20年以上前から、「ダイバーシティり「働き方改革」は同時 に進めてきた。この二つには密接な関倸があり、片方だけを進め ようとしても結果はうまくいかない

「24時間戦えますか」の時代は終わった。そ弓そろ「昔はつらかっ たけれど、良かった」という過去からオサラバしないと日本の医 療、ましてや外科は本当に崩壊しかねない。ロボットやAIでは解 決しない。“Our Business is People Business”だ!

PD02-1 子育て中の女性外科医の支援

中信勤労者医療協会 松本協立病院 外科

富田礼花, 具志堅進，小松健一，福澤俊昭，當間大樹。 佐野達夫

近年、女性が医学部を志望するケースが非常に増えている。そ れは必然的に女性医師の割合が増加することを意味し、外科分 野においても例外ではない。私は高校時代に部公でたまたま目 にした漫画に影響を受けて、突然医学部を志望して入学した。 外科医が主人公たったために短絡的に外科医なったものの、い ざ子どもが産まれると家事育児に追われ、仕事復帰しても保育 園の役員や地区の役員など外科医の仕事以外にも追われ、キャ リア形成が後回しになってしまった。縁あって現在は肚門外科 として地域の肛門疾患を多く扱っている。特に子どもや若い女 性患者に指名されることが多く、女性外科医のニーズを実感し ている。復帰に当たっては同僚達や祖父母や友人から多大な支 援を頂き、今日まで家族のため、患者さんの為に何とか働くこ とが出来ている。休日は子連れ出勤を許可して頂き、現在当直 は免除して頂いている。医局の一角に子どもの遊び道具も少し 置いて頂いたり、授業参観のため半日有給も取りやすくして頂 いている。その様子をて、他の常勤医や外部からのパートの 女性医師も子連水で出勤される事が多くなった。子どものちょ うとした体調不良で勤務体制に穴があく事が減少したように思 j子どもの成長に伴い、これからサブスペシャリティーを取 得していこうと考えている。子育ての時期を辞めずに乗り越え ることで、職場や社会に貢献できると思つている。

PD02-2 肛門科における女性外来の現状とこれから 大腸肛門病セン夕ー高野会くるめ病院 的野敬子, 荒木靖三, 松本朝子, 野明俊裕, 小篠洋之, 石見雅人, 石見拓人

肛門科受診は、女性にとって羞恥心のため、ハードルが高く何 年も悩んだうえ来院することが多い。当院では、2004年より女 性に特化した外来を開設し、2011年から女性専用スペースを設 け、取り組んできた。今回は、当院での取り組みと現状、アン ケート結果、今後について検討した。開放感のある院内スペー スにテレビ付きの待合室と広くて完全に仕切られた診察室を女 性外来とし、スタッフは医師も含め全員女性とした。当院には 3名の女性医師が診察し、可能な限り、内視鏡、手術も女性医 師で施行した。週に約 2 日間予約染を設け、完全予約制とした。 30 歳代の受診が多く、動機は、携帯からが多かった。最近の2 年で初診数350名、受診数は昨年より200件増であった。稼働率 は79\%であった。アンケート結果：診察に対してはプラスイメ ージ、施設に対してはマイナスイメージの書き込みがあった。 当院に拈いては、稼働率の上昇の検討が重要と思われる。今後 は、当院のような特殊分野のみならず、同性ということで相談 も兼ね、女性外来のニーズはあると考えられる。女性医師は、 出産後、手術がしたいからという理由で、復帰後周囲を巻き込 むのは、他に負担を負わせることになる。また、本当に女性か ら必要とされる分野として肚門科は、診察、手術、検查と全部 ひとりですることが可能であり、手術は短時間で術後の合併症 も少なく、女性外科医が無理なく仕事を続けていくうえで選択 の一つとなると考えられた。 
東京慈恵会医科大学附属病院 外科学講座 血管外科 大森槙子，原正幸，前田剛志，立原啓正，大木隆生

近年女性医師の増加に伴い, 外科系を選択する女性医師も増 えており,慈恵医大外科学講座では, 医局員285名中 28 名 $(9.8 \%)$ が女性である.特に卒後10年目以下の割合が多く,結婚。出産・ 育児などに対し,臨床外科医としてどのように関わっていくべ きか不安を抱えている女性医師は少なくない.また,私の所属す 方血管外科は中でも女性医師が少なく、緊急手術や重症患者の 多さ,被曝の問題など,女性血管外科医特有の問題も存在する。 回は女性臨床外科医が輝くための取り組みということで,血管 外科の立場から女性医師のあり方を考之当科の取り組みを紹 介する。慈恵医大血管外科は脳と心臓以外のすべて血管疾患 に携わっており,大動脈瘤破裂の緊急手術や新しいデバイスの 高難度手術など,貴重な症例を若いうちから経験させて頂いて いる、命の切迫した患者さんを前に，女性だからという甘えもな ければ,それだけ重大な仕事をしているというプライドも持つ ている.当科では術者選択や仕事の振り分けに招いて男女差別 はなく竞しろ個人のキャラクターを重視している、一方で、命 に直結するような高難度手術だけが血管外科医の仕事ではな く,末梢血管手術や下肢静脈瘤, フットケアなど女性であること が生かされる分野も多くある.男性医師と同等にと考えるので はなく,その時々の年齢や立場の中で,自分にしかできない仕事 を見つけ，女性にとって大事なものを犠牲にすることなく血管 外科医を続けていくことが大切だと思う。

PD02-4 当院の女性外科医勤務の現状

平塚市民病院外科 ${ }^{1}$ ，平塚市民病院救急外科 ${ }^{21}$ ，慶応義塾大学 病院消化器外科

本郷久美子 ${ }^{11}$, 原明日香 ${ }^{1}$, 筒井麻衣 ${ }^{1)}$, 葉季久雄 ${ }^{3}$, 米山公康 ${ }^{1,2}$, 高野公德 ${ }^{1)}$, 平田玲 1 , , 藤崎洋人 ${ }^{1)}$, 金子靖 ${ }^{22}$, 田島佑樹 ${ }^{12}$,

由良㚛大 ${ }^{12}$, 林啓太 ${ }^{1}$, , 中川基人 ${ }^{1}$

【はじめに】女性外科医の数は増しているが、継続して一線で 働いている数は経験年数に比例して少なくなると言われてい る。女性外科医がいかにキャリアを継続するかが、これからの 外科の課題であると言える。平塚市民病院外科では自身を含め、 今年度 2 人、前年度 3 人の女性外科医が常勤勤務しており、当 院での現状を報告守る。外科医A】卒後 18 年目、既婚で 2 児 子育て中 専門：下部消化管 留意事項：当直免除院内託児 所の利用等 [外科医 $\mathrm{B}]$ 卒後 7 年見、既婚で一児子育て中。専 門:乳腺 留意事項：当直免除時間外勤務免除院内託児所 の利用【外科医C】昨年度まで在籍、現在留学中。卒後13年目、 独身 専門:上部消化管留意事項: なし[考察】当院の現状 から考察すると、女性外科医が勤務継続可能である条件として 1、院内託児所、当直免除等、病院としての設備、規則整備等 2、交代人員の必要性、当直やオンコールの代替システム $3 、$ 資格の取得、自身の特性を持つこと等が考えられた。ライフイ ベントは女性、男性に限らずおこることであり、それに仕事が 左右されることは女性に限ったことではない。しかし、坠て は比較的若年で起きるイベントであり、キャリア形成の時期に 大きく左右する。これをシステ公の面でいかにカバーできるか が重要であり、このことは外科全体の職場改善にもつながる今 後の課題である。

PD02-5 育児中の女性消化器外科医がバリバリ働くため に -2 施設間の比較

土浦協同病院 ${ }^{1}$ ，自治医科大学さいたま医療センター一般消 化器外科2

長欲川芙美 ${ }^{1)}$, 滝口典聡 ${ }^{1)}$, 松本日洋 ${ }^{1)}$, 伊東浩次 ${ }^{1)}$, 有田カイダ ${ }^{1)}$, 春条茂男 1), 上田浩樹1), 大畠慶映1), 谷岡利朗 1 ), 齊藤正昭 2 ,

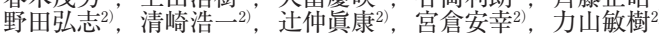

修練と妊娠出産、育児の時期が重なり、外科医としてバリバリ働 尖のをあきらめる者も多い。育児をしながら、2つの地域がん診 療連携拠点病院で消化器外科医 (大腸専門、救急も対応) として 㗢く経験をもとに、赛際に女性消化器外科医唯継続して勤務专る ためには何が必要か検証してみた。施設 Aは大学の分院、施設 $\mathrm{B}$ は一般病院である。Aは628床、Bは800床、年間手術件数は A998 件 (うち大腸癌132件)、B1068件 (182件)、消化器外科医17人、 12 人と大きな差はない。女性消化器外科医が㗢くためには、(1) 保育所などの施設 $(2)$ 労働時間 (3) 周囲の協力が問題となる。 (1) 突然の発病に対応してくれる病览保育 $(A)$ や夜間保育 (と もになし)があると働きやすい。(2) チー公制 (A) だと、早朝、 夕方の回診、カンファレンスなど自身では時間を変更しにくい。 主治医制 (B) だと、時間の融通が利く一方、緊急事能に呼び出 される事がある。また、医療事務作業補助による業務分担が多い と (B)、医師の仕事が軽減し、手術の時間を確保できる。(3) 施設間の違いはなく、朝のカンファレンスには途中参加を容認し てもらい、不足内容は自身で確認する。また、当番日以外の時間 外手術は、保充園の時間にあわせて交代を㹉いしている。 めると、女性外科医の活躍を応援するためには、病児保育など緊 急時の対応ができる施設の充実、医療事務作業補助による医師の 負担軽隇、周囲の協力が重要である。
PD02-6 女性外科医が活躍するために必要なこと ～独 身女医の負け大の遠吠え 伊勢崎市民病院

塚越律子, 渡辺裕, 飯島岬, 家田敬輔, 諸原浩二, 大澤秀信,

片山和久，鈴木秀樹，富澤直樹，保田尚邦，田中司玄文

女性外科医は結婚・出産・育児といったライフイベント後のキ ヤリア形成が課題となり、両立支援が必要である。しかし、両 立支援は出产後の女性外科医だけに必要なのであろうか。 出産後でも女性外科医が働けるような環境を整えるとの名目 で、出産後の女性外科医は当直・待機が免除され、時間内に仕 事が終わるように配慮されるが、之の分の仕事を男性外科医掠 よび子供のいない女性外科医が負担することになる。結婚・出 产の予定のない私が不満を言ったとしても「子供がいないから わからない」と言われてしまう。子供が何歳になったら復帰す るつもりなのだろうか。また、当直や待機をしないということ はキャリ方形成において障害にならないのだらうか。光分負 担がかかる私たちは不満を内に秘我慢するしかないのであろ うか。

まずは女性外科医の意識改革が必要ではないだろうか。女性外 科医への支援は女性が家事・育児をしやすい環境を整える目的 ではなくあくまでも外科医としてのキャリアを皘むことが目 的である。女性外科医自身が当直・待機免除ということに甘ん じることなく、できるだけ早くに一線に復䚻することが重要で ある。また、チーム制の導入・医師事務補助の活用等で長時間 労働を前提とした外科医の働き方を改善をすることで、女性外 科医だけでなく男性外科医も同様に負担を減らし、キャリ宁を 形成していける環境づくりが必要と考えられる。

PD03-1 消化器手術後の創直下癒着リスクの検討 長崎みなとメデイカルセンター 外科

渡海大隆, 松本亮, 福本将之, 松隈国仁, 平原正隆, 崎村千香, 野田和雅，南恵樹，谷口堅，原口正史，井上啓爾

【はじめに】消化器手術後の癒着性イレウスには様々な原因が あるが、創への腸管癒着もその一つとされ、様々な瘉着防止対 策が考えられてきた。目的】創への癒着の頻度や要因を解析し、 瘾着性イレウスの発生や再手術時の腸管損傷リスクを検討す る。【対象と方法】2013年 1 月〜2018年12月までに当セン多二 で施行された全麻・腰麻症例 4858 例のうち、同一患者に開腹手 術を 2 回以上行われた症例を後方視的に検討。対象症例の再手 術時に、創に癒着が涊められる割合を手術因子別に検討した。 【結果】該当する432手術のうち初回手術が (1) 腹膜炎や污染 手術、（2）瘾着性イレウス手術、（3）人工肛門閉鎖術、(4 メッシュを用いた腹壁へルニア手術を除外。また、再手術が（1 前回手術の創が観察できない、(2) 術後 1 ケ月以内の再手術 などを除外したところ、対象は192手術96症例（重複含む） あった。全例でラップ型の創縁保護具を使用していた。再手術 時、創に癒着を認めたものは35例 $(38.9 \%)$ であり、瘉着臓器 は大網のみ 24 例、小腸 5 例、大腸 5 例、胃 1 例であった。手術 時間、出血量、腹哚鏡手術、瘉着防止剂貼付、閉創法、縫合系 などのうち癒着と有意な相関を認めたものは腹腔鏡手術のみ $(\mathrm{P}=0.04)$ であり、腹脘鏡手術後に腸管が瘉着していたものは 3 例 $(4.2 \%)$ のみであった。結語】腹腔鏡手術では創直下の 腸管癒着の可能性は低く、初回手術時に特段の癒着防止策を講 じなくても再手術時の腸管損傷リスクは低い

PD03-2腹腔鏡下大腸切除術における吸収性瘉着防止フ イルムによる術後癒着性腸閉塞の予防 駿甲会甲賀病院1), 国際医療福祉大学市川病院消化器外科 2 , 帝京大学外科 ${ }^{3)}$, 横浜市立大学付属市民総合医療センター4) 藤井正一1,2,34)，出口貴司 ${ }^{1)}$ 有村隆明 ${ }^{1)}$ ，金澤真 $\left(\right.$ 作 $^{1)}$ 堤謙二 ${ }^{1)}$, 内山周也 ${ }^{11}$, 今井俊一 2 , 天年山隆史 2 , 板野理 2 , 塚本充雄 ${ }^{3)}$ 島田竜 ${ }^{3}$, 端山軍 ${ }^{3)}$, 松田圭二 ${ }^{3}$, 橋口陽二郎 ${ }^{3)}$, 石部敦士

【背景】腹胿鏡下手術の普及により瘉着性腸閉塞（BO）は減少してい るが、依然として臨床上問題である。我々は2009年より癒着防止目的 に腹䏕鏡下でも吸收性瘉着防止フィルム (以下SF)を使用してきた 【目的】腹胿鏡下大腸癌手術におけるSFのBO予防効果を検証守る。【手 技】SFは閉腹直前に開腹創直下に敷石状、 $12 \mathrm{~mm}$ 卜ロッカーから 㨂入もしくはセプララップ使用貼付を行った。貼付有無は術者判断と した。【方法】2009-18年手術でミ1 年観察した997例を対象にSF貼付 有無 (有: S群、無: N群) でBO、他合併症発生率を比較した。非切除 開腹移行、不適切デー夕および術後 7 日以内、排便・排ガスなしは麻 㾄性として除外 Lた合併症Grade 4 Clavien-Dindo分頪とした回 瘦性分析に上 啫分析によ例で、背景はS 群にStage4、人工朋門造設術が多かった。 BO 50 例 $(5.0 \%)$ に認め36例 $(3.6 \%)$ が術後30日以内発症であった。 BO 発生率 (S群: N $\mathrm{N}$ 群) は3.7\%:5.7\% ( $\mathrm{p}=0.166)$ で差がなかったが、30 白以早期 $\mathrm{BO}$ はS 群に少なかった $(1.7: 4.6 \%, \mathrm{p}=0.016)$ 。 は差なく $0.9: 0.9 \%, \mathrm{p}=0.911) 、$ Grade3a早期 BO は $0.6 \%: 3.7 \%$ ( $\mathrm{p}=0.003)$ でS群が少なかった。他合併症はS 群に縫合不全少なく、梁部SSI 差なし。多変量解析でBOリスクは人工胿門造設術で、早期 BO 術でもSFは合併症りスクを高めずに早期発症 BO予防に有用である。 
PD03-3

大腸癌術後イレウスに対する治療と予防

市立奈良病院 消化器外科

濱田隼一, 中瀬有遠, 山田一人, 宮前眞人, 永田啓明, 天池寿, 稲葉征四郎

【緒言】大腸癌術後の癒着性イレウスは臨床でしばしば遭遇す る。当院で大腸癌に対して大腸切除された症例において術後イ レウスを認めた症例について後方視的に検討し、当院における その対応策について報告する。【方法】当院にて 2013 年から 2018年までに原発性大腸癌に対して開腹下および腹䏕鏡下に大 腸切除された433名において、結腸切除+機能的端々吻合術群(C 群)、結腸もしくは直腸切除 +DST再建術、Hartmann 手術、 Miles 手術、括約筋間直腸切除術群 (R群) の 2 群に分け術後 イレウスについて検討した。結果】術後イレウスを認めたの はC 群、R群でそれぞれ10例 $(4.8 \%) 、 18$ 例 $(8.0 \%)$ であった。 またイレウスに対して外科的加療を要した症例はC群、R群で それぞれ3例 $(30 \%) 、 7$ 例 $(39 \%)$ であった。C群で手術加 療を要した 3 例のうち 2 例は吻合部近傍への強固な小腸の瘉着 が原因であり、1 例は小腸間膜間に形成されたバンドが原因で あつた。R群においては 7 例中 6 例が骨盤部腹膜欠損部近傍で の小腸癒着が原因であった。1例は間膜同士間に形成されたバ ンドが原因であった。【対策】以上の結果から直腸間膜欠損部 が生じる症例に対しては同部位への癒着防止フィルムの貼付も 妥当であると考えられるが、腹腔鏡手術においては同部位への フィルム貼付は容易ではない。そこで癒着防止フィルムをポー トからでも挿入可能にする方法・デバイスを開発し、同部位へ の癒着防止フィルム貼付を実践しており紹介したい。
PD03-6

川崎幸病院 外科

伊藤慎吾, 杉山敦彦, 富澤悠貴, 左近龍太, 井上貴博, 小根山正貴, 下島礼子, 原義明, 成田萂広, 藤野莽兰, 旦骨裕司, 後藤学, 関川浩司

背景 : 消化器外科領域において術後の瘉着による腸閉塞は入院 期間の延長や再手術のリスクとなる。近年、様々な癒着防止材 が登場しており、2016年12月より保険収載されたアドスプレー (テルモ) は、長いノズルをトロッカー上り挿入し鏡視下に腹 腔内へ噴霧できる新しい夕イプの瘉着防止剤である。目的: 当 院では2018年 1 月より消化器外科領域でアドスプレーを使用し ており、その治療成績について検討した。対象：2018年1月か ら2019月2月までの間、術中にアドスプレーを使用した25例に ついて検討した。結果：平均年齢は70.1歳、男性：17例、女性 8 例、平均BMI 222.4、観察期間中央値は219日 (98から498 であった。術式は幽門側胃切除：3例、直腸切除：9例、結腸 切除：9例、肝切除：3例、腸閉塞手術：1例、開腹による腹 会陰式直腸切断術の 1 例を除いて全例か腹腔鏡手術の症例であ つた。平均手術時間は 294 分。平均出血量は $38 \mathrm{~g}$ 。平均在院日 数は16日であった。大腸癌の手術症例で縫合不全を 3 例に認め 1 例で再手術を要した。期間中の腸閉塞の発生はなく、その他 に癒着防止剂に起因する可能性が考えられる合併症は認めなか つた。結語：アドスプレーは安全に使用可能であり、術後の腸 閉塞予防への有用性が示唆された。今後も症例の集積を重ねて 報告守る。
PD03-4 術後腸閉塞発症予防に対する当院の工夫 -大 網弁と癒着予防シートの活用

長崎県島原病院 外科

蒲原行雄，黒島直樹，円城寺貴浩，中山正彦，木下綾華

背景) 術後腸閉塞の発症は術後患者の回復を遷延させ医療経済 にも悪影響を及ぼす。われわれは術後癒着性障害が腸間膜郭清 による欠損部や肝切除後の死腙・肝門部近傍に発生しやすいこ とを経験し、2017年 9 月以後、胴部に大網弁の充填と対応臓器 に酸化再生セルロース性の癒着予防シート貼付を導入してい る今回之の雄王政検証した方法）2015年からシート䕗入 以前（非導入群）の肝切除14例、大腸切除 155 例と導入後の肝 切除15例、大腸切除68例 (導入群) と患者背景、術式 (切除範 囲、鏡視下 / 開腹)、術後癒着障害について比較検討した。結果 いずれも背景因子や術式間で差はなかった。術後癒着障害にお いては肝切除では差を認めなかったが、左葉系切除で画像上胃 の偏位が導入群で少く、導入症例では再切除が容易であった。 大腸切除では非導入群では22例 $(13 \%)$ に薬物投与や減圧を要 する腸閉塞が発症し、画像上では郭清部や久損部近傍の通過障 害が疑われた。このうち 3 例が再手術となった。一方、導入群 では検討した68例で治療を要する腸閉塞の発生は認めなかった $(\mathrm{p}<0.05)$ 。結論) 術後癒着は創面への癒着のみならず、手術 で展開した郭清部/切離部、断端への瘉着の関与も少なくなく 術後瘉着性障害の予防には欠損部死腙の大網弁による物理的な 閉鎖と同部あるいは対応臓器への癒着予防のシート貼付が有用 であることが示唆された。

PD03-5 討と今後の展望

上村直, 北川博之, 前田将宏, 津田祥, 谷岡信寿, 藤澤和音, 宗景匡哉, 前田広道, 並川努, 花崎和弘

【はじめに】肝切除術時における瘉着防止剤の使用は、次回開 腹時における癒着の軽減や術後腸管癒着の軽減において重要で ある。特に左側肝切除術では癒着による胃排泄遅延が問題とな ることがある。肝切除後噴霧型癒着防止材の有効性について检 討した。【対象と方法】2017年 7 月から2019年 5 月までに胆管 切除や他藏器合併切除を伴わない肝切除術後、噴霧型癒着防止 敦、アドスプレー（TERUMO社、東京）を使用した58例を対 象とした。噴霧方法は閉腹前に肝離断面を除く、切開創部直下、 肝表面、肝門部、胃壁に噴霧した。胃排泄遅延を含む術後合併 症、入院期間について検討した。【結果】年齢70 11 歳、男性 41 例。疾患は肝細胞癌 28 例、転移性肝癌14例、肝内胆管癌 6 例、 肝内結石症 3 例、その他 7 例で、術式は肝葉切除術例10例 (左 葉 8 例、右葉 2 例)、区域以下の肝切除術48例であった（腹腔 鏡下切除 3 例）。術後入院期間 $11 \pm 15$ 日で、術後合併症は胆汁 漏 4 例 (7\%) SSI3例（5\%) その他 2 例であった。腸閉塞 を 1 例に認めたが術創部に関係のない癒着性腸閉塞であった。 胃排泄遅延はなかった。【結語】噴霧型瘉着防止剤は胃壁に方 遍なく噴霧できるため、肝離断面に胃が癒着し胃軸捻転を来し うる症例で有用な可能性が考えられた。
PD03-7

検討

東京大学 腫瘍外科

田中敏明, 園田洋史, 石井博章, 室野浩司, 江本成伸, 金子学, 佐々条和人, 西川武司, 秀野泰隆, 畑啓介, 川合一茂, 野澤宏彰, 石原聡一郎

【背景】腸閉塞は対する腹腔鏡下手術は、低侵襲という利点が 有る一方、腸管拡張や癒着などの手術を困難にするとされる要 素を含んでおり、現状では明確な適応基準が示されていない。 今回、腸閉塞に対古る腹䏕鏡下手術の治療成績を検証し、その 利点や問題点を明らかにすることとした。方法】2012年 1 月 から2018年12月までに当科で手術を行った小腸イレウス症例を 後方視的に検討した。【結果】58例に対して手術が行われた。 40例が開腹手術、18例が腹腔鏡下手術で行われた。閉塞の原因 は、バンド16例、瘉着が15例、腫瘍12例、ヘルニア12例、その 他 9 例（重複を含む）であった。Clavien-Dindo GradeIII 以上 の合併症は 5 例に認められた。開腹手術に比べて腹腔鏡下手術 は、絞扼の症例が少ない傾向にあった。手術時間、術後合併症 は同等であり、術後腸閉塞の発生は有意差を認めなかった。次 に開腹移行症例についての検討を行つた。腹䏕鏡下手術18例の うち13例が完遂、5 例が開腹移行となった。腹胿鏡下手術で完 遂した症例は閉塞の原因がバンドの症例が多い傾向にあった バンド症例 腹腔鏡完遂 $69 \% \mathrm{vs}$. 開腹移行 $20 \%, \mathrm{p}=0.055$ )。 開腹移行の理由は、高度な癒着や小腸の拡張のため、腹腔鏡下 での視野確保の難薬が原因であった。【結論】バンドによる腸 閉塞は腹腔鏡下手術の良い適応と考えられるとともに、視野の 確保が困難な場合は、開腹への移行を考慮すべきである。

PD03-8 開腹手術後の癒着の安全な剥離方法 - 生理食塩 水組織間注入法についで堀内哲也, 大津周, 中井智䡒, 木村正道, 藤田洋一, 辻俊明, 富永敏治, 稲田佳紀

術後瘉着性腸閉塞の予防のため、腹腔臓器の乾燥の防止、腹腔 内の洗浄等による壊死物質・異物の除去、癒着防止剂の使用、 術式の検討（腹腔鏡下手術の選択）などが行われているが、(小) 開腹手術後には少なからず癒着が存在し、再手術を行う場合、 術中に臓器損傷をきたすこともある。また腸管の癒着に対する 腹望鏡下治療も行われているが、腸管同士に高度な癒着がある 場合は開腹移行になることも多い。開腹手術後の癒着の剥離の 方法は1970年代には重要視されたが、最近では手術書などにも あまり記載されていない。過去には、腸管損傷の防止のために 局所麻酔薬入りの溶液を注射器に針をつけて消化管等の癒着部 に注入し、間隙を剪刀で切るという方法が報告されている。わ れわれは局所麻酔薬のかわりに針をつけない状態の $20 \mathrm{cc} の$ 注 射器に生理食塩水を入れ、癒着した組織間に生理食塩水を注入 することで、組織の間隙を広げ、その間隙に剥離鉗子をいれ、 電気メスで切開する方法（生理食塩水組織間注入法と命名）を 行っている。これにより組織間隙を広げずに剪刀で切るよりも 安全に癒着の剥離・切離ができ、腸管などの損傷が防げると考 えている。2012年より癒着性腸閉塞の手術時のみならず、高度 な癒着のあるがん手術18症例に対しても、本法を施行し、目的 の笔術を安全に施行できたため、その成績を報告し、本法をビ デオで供覧する。腹腔鏡下手術が難しい高度癒着例に対してこ そ、本法は有用と考えている。 
PD04- 基調講演

肝胆膵外科ロボット支援手術の将来性

上尾中央総合病院外科 ${ }^{1)}$, 肝胆膵先進治療センター 2 若林剛1,2

腹腔鏡下肝切除を初めて行なったのは1995年で、初めてダビン チに触れたのは2000年であったその時は腹腔鏡下肝切除がこ れほど発展・普及するとは思っていなかった。また、多ビンチ で腹腔鏡下胆襄摘出術を行なったのだが、自分にとってはダビ ンチを使用しない方が良い腹腔鏡下胆囊摘出術ができると考え ていた。ただ漠然と感じていたのは、膵頭十二指腸切除こそ ダビンチを使用すべきであると。2014年に盛岡で第 2 回腹腔鏡 下肝切除の国際コンセンサス会議を主催し、2019年に東京で第 2 回国際肝茞内視鏡外科学会を開催した。もはや腹腔鏡下肝切 除は低侵襲手術の域をこえ肝臓外科の主要な領域へと発展し た。二方、脺蔵外科でも同じように腹腔鏡下脺切除が発展・普 及するのだろうか？腹腔鏡下膵頭十二指腸切除を行なった患者 に、膵液漏のため 3 ケ月の入院をしいてしまつた。自分には膵 管粘膜空腸吻合を腹脭鏡下に巧みにできる技術は無い。そこで ロボット支援下膵頭十二指腸切除を開始した。開腹で行なう吻 合より精度の高い膵管粘膜空腸吻合ができるのではと考えてい る。これまでに、われわれが行つたロボット支援腹腔鏡下膵頭 十二指腸切除術 (RPD) 17例と膵中央切除術 (RCP) 1 例では、 RPDの手術時間、出血量の中央值は814分、237mlで、術後膵 液㾇は18例中 Grade B1が 1 例であった。今後、手技のさらな る定型化により、手術時間の短縮は可能であると思われる。膵 頭十二指腸切除と膵中央切除はロボット支援腹腔鏡下手術が主 流になると思うが、ロボット支援腹腔鏡下肝切除に関してはさ らなるデータの集積が必要であろう。

\section{PD04-1 ロボット支援尾側膵切除術の経験}

千葉大学 臓器制御外科学

吉富秀幸, 高屋敷吏, 古川勝規, 久保木知, 高野重紹, 鈴木大亮, 酒井望, 賀川真吾, 三島敬, 中台英里, 大塚将之

【緒言】ロボット支援手術は保険適応が拡大され、本邦でもよ うやく広がりつつあるものの、肝胆膵領域はほとんど行われて いないのが現状である。我々はこれまで7例のロボット支援尾 側脺切除術 (RDP) を施行したので、その経験を報告する。

【方法】2013-2015年に院内の倫理委員会の承認を得て臨床研究 として低悪性度膵腫瘍に対するRDPを施行。これらの結果を 後乃向きに解析。

【結果】7例にRDPを施行。全例でdaVinci-Sを用いた。臍部 よりカメラポート、脾門部を中心に円弧状に広がるように3本 のアーム用と 1 本のアシスタントポートを挿入し、計 5 ポート で施行。男女比は 3:4、SPN3例、MCN1例、NET1例と全例 が低悪性度腫瘍。全例、脾合併切除施行。手術時間は384 23 分、 出血量は $98 \pm 103 \mathrm{ml}$ 。全例、自動縫合器にて膵切離を施行。在

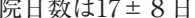

【結語】daVinci システムを用いたRDPでは良好な視野のもと、 その操作性の良さにより安全に手術を施行できたが、依然、現 時点での手術件数では習熟段階にありその利点を具体的に示せ ていない。資金の問題により現時点では本手術の継続が困難な 状況である。しかし、関節機能など通常の腹腔鏡下手術では不 可能な操作が可能であり、今後、デバイスの開発、コスト削減 を通し保険収載されれば肝胆膵疾患における低侵襲手術の広が りにつながると期待できる。

PD04-2

ロボット支援下膵頭十二指腸切除術のPros

東京医科大学 消化器 - 小児外科学分野

永川裕一, 瀧下智恵, 刑部弘哲, 木谷嘉孝, 赤司昌謙, 西野仁恵, 勝又建次, 土田明彦

腹腔鏡下膵頭十二指腸切除術（LPD）は切除，再建ともに複雑 な操作を必要とし他の腹腔鏡下手術と比較し難度が高い. PD 術後の重篤な合併症を予防するには，確実な膵再建が必要であ るが腹腔鏡下での再建では高度な縫合技能が要求される. 一方, ロボット支援下膵頭十二指腸切除術 (RPD) では極めて正確 な縫合が可能であることから，膵液瘦発生率を減少させる上で も期待される.また剥離操作においても自由度が高いことから， 必ずしもデバイスの軸を合わせる必要がなく，より正確な層で の剥離操作を可能とする。また拡大視効果においても，RDP では3D画像のもと神経線維や疎性結合織などの緎細な解剖棒 学的構造の認識が可能である. 特に総肝動脈や胃十二指腸動脈, 肝十二指腸間膜周囲では, LPDより正確な剥離操作を可能と する。しかしながら，術野展開では，腹腔鏡下手術では 3 本の 錐子を用いた三角展開が可能であるがロボット手術では 2 本の 銝子で展開することなる。十分な術野展開を必要とする上腸間 膜動脈周囲での剥離操作では 2 点支持での展開より三角展開の 方が操作しやすくRPDはLPDより不利となる。また使用守る 切離デバイスは腹腔鏡下手術の方がより精度が高い.われわれ が考えるLPD と RPDの利点と欠点について報告する.
PD04-3 先天性胆管拡張症成人例に対するロボット支援 腹腔鏡下肝外胆管切除術

東北大学 消化器外科学分

森川孝則, 呙藤剛, 石田晶立, 高舘達之, 伊関雅裕, 有明恭平, 川口桂，益田邦洋，水間正道，大塚英郎，林洋毅，中川圭，

元井冬彦, 亀井尚, 海野倫明

[背景] 先天性胆管拡張症成人例に対する治療は, 拡張胆管の切除 执よび膵液逆流の防止を目的とした分流手術を行う必要があり, 低侵襲手術の良い適応である。また，手術野が限定され吻合を用 いた手技が必須であることから，ロボット支援手術に適した術式 と考えられる。当科では倫理委員会の承認を受けた後, 本術式を 5 例に対し施行したので, 年手術成績につき報告する。[手術手 技］戸谷I型を適応とし，体位は開脚位で開始寸る。空腸空腸吻 合を先に作成し, 総肝管周囲を剥離し, 総肝管を切離する。総肝 管を旁引しつつ総胆管剥離を膵内まで可及的に剥離した後、胆管 を王に結䅨し肝外胆管を切除する。挙上空腸と肝管を $4-0$ PDSにて連続吻合し, 手術終了となる。[結果] 手術時間中央値 は548 (391-615) 分であり、出血量は10 (3-140) mL. 1 例術後 腸閉塞により癒着剥離術を行った症例があったものの, CD III 以 上の術後合併症はこの 1 例のみであった 同時期に行った腹腔鏡 下手術との比較では，背景・術後因子に差はなかったが手術時間 が有意に長時間であった $(\mathrm{p}=0.049)$. しかし, 吻合部狭窄なと の長期合併症は認められなかった. [結語] 先天性胆道拡張症に対 するロボット支援手術は, learning curveを克服する必要があり 現時点では明確な利点を提示はできない。しかし，吻合の確実性 による長期合併症の軽減という利点が考えられ, 今後の保険収載 を期待したい.

PD04-4

膵臓外科領域におけるロボット支援手術の位置

九州大学 臨床・腫瘍外科

中村雅史

2018年 4 月の保健改定でロボット支援下内視鏡手術が一挙に12 件保険適用となり、現時点で合計14件が保険下に施行可能とな つている。しかしながら膵臓に対するロボット手術は未だ保険 収載されていない。腹腔鏡下手術と比較したロボット手術の利 点は骨格等で限られたスペースにおける切除、細い径の吻合を 含む複雑な再建術等と言われている。膵がんの代表的な術式で ある膵頭十二指腸切除術は直系 $1 \sim 2 \mathrm{~mm}$ 程度である主膵管の 吻合が必要であり、膵体尾部切除は胁骨で制限された空間での 切除が必要である。2術式ともいわゆるロボット手術の利点が 生かせる術式と思われる。以下に膵がん治療の現況、およびロ ボット手術の利点と実際の手技に関して概説したい。

PD04-5 ロボット支援下高難度肝切除術への展開と課題 藤田医科大学 総合消化器外科 杉岡篤, 加藤悠太郎, 棚橋義直, 犬飼美智子, 小島正之, 安田顕, 中嶋早苗, 宇山一朗

ロボット支援下肝切除（RLR）は発展途上の手技であるが、高 難度手技において腹腔鏡下肝切除 (LLR) を凌駕する可能性が ある。当科では2019年 7 月までにRLRを85例実施し、解剖学 的切除 (AR) 39例 (45.9\%)、非解剖学的切除 (NAR) 46例 (54.1\%) であった。ARの内訳は三区域切除 2 例、葉切除 7 例、前/後 区域切除 11 例、外側区域切除 5 例、S1を含む带区域切除 14 例であつた。また、15例にHassab 手術、胃切除、食道切除、 大腸切除、膵頭十二指腸切除などを併施し、胆道再建を 2 例に 行うなどRLRはより高難度症例が多かった。ARのコンソール 時間は664分、出血量は631g でLLR (AR) やNARよりも高值で、 在院日数は18日でLLR (AR) と同等であったが、NARよりも 長かった。合併症率（CD ミIII） は $20.5 \%$ とLR (AR) やNAR より高く、90日死亡を 1 例認めた。高難度肝切除における RLRの利点は、多関節機能やフィルタリング及びスケーリン グ機能による肝外グリソン鞘一括確保や胆道再建にあるが、喫 緊の課題は肝実質切離デバイスや脈管剥離・郭清操作における 纎細な鉏子等の拡充である。経済性もRLRの大きな課題で、 現在RLR は自費診療であるが、高難度手技におけるRLRの優 位性は明らかであり、新規手術支援ロボットやデバイスの開発 とともにRLRの保険収載が期待される。 
PD05-1 系統的切除が有効な肝細胞癌症例の選択

静岡がんセンター 肝胆膵外科

岡村行泰, 杉浦禎一, 伊藤貴明, 山本有祐, 蘆田良, 大木克久, 手塚康二, 上坂克彦

背景 : 我々は、肝細胞癌 (HCC) に対する系統的切除 (AR) が 非系統的切除 (NAR) と比較し、予後に有意差がないことを 報告した。一方で、顕微鏡的脈管浸潤 (MVI)、肝内転移 (MIM) を有する症例ではARがNARより有効である可能性がある。 目的：MVI, MIMの術前予測因子を抽出し、リスク別にAR と NARについて比較検討卞る。対象と方法: 2002年 9 月から 2017年 7 月までに、術前画像で脈管浸潤、肝内転移を認めない 初発かつ単発HCC 389切除例を対象とした。検討 1 : MVI and/or MIM $の$ 有無で比較検討 L、MVI, MIM $の$ 術前予測因子 を抽出する。検討 2 : リスク因子保有数別に、ARとNARで 比較検討した。本検討では、脈管浸潤は、門脈、もしくは静脈 浸潤と定義した。結果：検討 1 ：MVI, MIMの術前予測因子は AST、血小板数、DCP 高值、腫瘍径大の 4 因子であった。検 討 2 ：リスク因子を $1,2,3,4$ 有守る症例は、それぞれ全体 の $89 \% 、 58 \% 、 29 \% 、 11 \%$ 市り、リスク因子が増えるにつれ、 $\mathrm{AR}$ 施行率が有意に上昇した $(\mathrm{P}<0.001)$ リスク因子別の術 後無再発生存期間中央值（RFS）は、それぞれ108，35，32，36, 10 ケ月で、リスク因子 0 で有意に良好、リスク因子 4 で不良 であった。リスク因子 2 の症例に扔いて、ARのRFSがNAR より有意に良好であった $(38.4$ vs. 24.8 ケ月、 $\mathrm{P}=0.021)$ 。その ほかの subgroupでは、AR有用性は認めなかった。結語： MVI, MIMの術前予測因子を2つ有するHCCにおいては、AR を行うべきと考えられた。

\section{PD05-2肝細胞癌の腫瘍局在に着目した系統的切除の意}

義 乯良県立医科大学 消化器・総合外科

北東大督, 野見武男, 吉川高宏, 紙谷直毅, 松尾泰子, 赤堀宇宏, 中川顕志, 長井美奈子, 中村広太, 高木忠敬, 池田直也,

庄雅之

【諸言】肝切除で $\mathrm{R} 0$ 手術を目標とする場合, 表在性腫瘍は最小限 のマージンで切除できる。一方, 梁在性腫瘍は肝表面から腫瘍ま での肝実質を合併切除する必要がある。つまり肝細胞癌の非系統 的切除は表在性肝細胞癌では核出術に, 哚在性肝細胞癌では系統 的切除に近い切除になる。今回, 肝細胞癌の腫瘍局在に着目して 系統的切除の意義を検討した。【対象・方法】表在性肝細胞癌は腫 瘍最樑部が肝表面から $3 \mathrm{~cm}$ 以下, かつ腫湯径 $5 \mathrm{~cm}$ 未満の腫瘍と定 義. $2007 \sim 2015$ 年に肝切除を施行した初発肝細胞癌176症例を梌 討.【結果】表在性肝細胞癌は93例 $(52.8 \%)$, 深在性肝細胞癌は 83 例 $(47.2 \%)$ ，表在性肝細胞癌の 23 例 $(24.7 \%)$ に系統的切除, 70 例 $(75.3 \%)$ に非系統的切除を施行. 無再発生存率は系統的切 除で有意に良好であった $(2 / 5$ 年無再発生存率 $: 100 / 71.4 \%$ vs. $71.4 / 34.2 \%, \mathrm{P}=0.006$ ) 一方, 全生存率には有意差はなかった。深 在性肝細胞癌では56例 (67.5\%) に系統的切除, 27例 (32.5\%) に 非系統的切除を施行. 両群で無再発生存率, 全生存率に有意差な L. 表在性肝細胞癌の背景因子でHCV 抗体陽性率, 血清 ALB 值, PT\%に有意差がありプロペンシティマッチングした各群20例て 再検討したところ無再発生存率は系統的切除で優位に良好 $(\mathrm{P}=0.030)$. 同一亜区域内再発は, 非系統切除群の 4 例 $(20 \%)$ に 認めた。【結語】表在性肝細胞癌に対与る系統的切除は無再発生存 率が良好で, 意義があると考えられた。

PD05-3 単発肝細胞癌に対する肝部分切除後の再発形式 からみた系統的肝切除を選択すべき因子の検討

広島大学 消化器. 移植外科

浜岡道則, 小林剛, 大平真裕, 田原裕之, 黒田慎太郎, 本明慈彦, 山口恵美, 山本将輝, 竹井大祐, 大段秀樹

【目的】

肝細胞癌に対して部分切除が施行された症例に揖ける再発形式の違い から、どのような症例に系統的肝切除が必要であったかを推測するこ とを目的とした。

【対象と方法】

2008年 1 月から 2017年12月までの肝細胸癌切除症例のうち、初回肝切

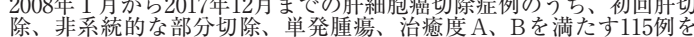
対象とした。再登形式として、無再発、肝切除部位と同一亜区域内の 再発、同一带区域外の再発に分汸て、それぞれの臨床病理学的因子に ついて検討を行った。

【結果】

対象症例の腫瘍径中央值は17（5-51） mm、肝表面からの距離中央 值は0.8 (0.1-17.6) mmであった。再発は52例 $(45 \%)$ に認め、15例 (13\%) が同一曲区域内再発であった。再発症例は無再発症例に比べ有意に AFP、PIVKA-IIが高值、vp1の症例が多かった。また、腫瘍径が大 きく、背景肝の線維化が進行している傾向があった。再発症例におい ては、同一带区域内再発は同一带区域外再発に比べ有意にPIVKA-I が高値、単純結節型以外の腫瘍が多かった

[考察]

PIVKA-IIが高值の症例、単純結節型以外の腫瘍は同一带区域内再発 が多かったことは、これらの腫瘍は門脈行性に転移をきたす可能性が 高いという特徴を反映しているのかもしれない今回の対象症例の大 多数が肝表面の腫瘍であったが、上記の条件を満たすような症例では 系統的切除を考虑してもよいかもしれない。
PD05-4 $5 \mathrm{~cm}$ 以下、単発肝細胞癌に対する解剖学的切除、 非解剖学切除の長期予後の比較

山口大学大学院消化器 - 腫痬外科学 ${ }^{11}$, 山口大学医学部 先 端がん治療開発学 2 , 崩口大学医学部附属病院腫瘍セン多 - 3), 川崎医科大学 消化器外科 4

松德聰1)，德光幸生 ${ }^{1)}$ 、新藤芳太郎 ${ }^{1)}$, 松井洋人 ${ }^{1)}$, 中島正夫 ${ }^{1}$,

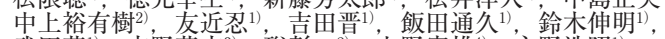
武田茂 ${ }^{1}$, 吉野茂文 ${ }^{3)}$, 破彰一2), 上野富雄 ${ }^{4)}$, 永野浩昭 ${ }^{11}$

【背景】肝細胞癌（HCC）に対する肝切除は肝機能が許容される限り解剖学的 切除が推将されているものの長期予後については議詥が市る。解剖学的切除 (AR) と非解剖学的切除 (NAR) の長期予後について梌討した。

【対象と方法】当科で初回肝切除を行った肉眼的脈管侵龍のない単発 $5 \mathrm{~cm}$ 以下 HCC、Child-Pugh A の226例を対象とし、AR群 (146例) と NAR 群 (80例) に分け、背景因子を比較した。また背景肝機能や腫場因子により術式選択に偏 りが生じているため、年齢、術前Alb值、ICGR15值、血小板数、PT活性、 T-bil值、腫掦径、背景肝の線維化、微小脈管侵襲を用いて傾向スコア (PS) を算出し、PSマッチングおよびPSの逆数により重みづけを行う inverse probability of treatment weighting(IPTW) により AR 群とNAR 群間で患者背景 のバランスが取れた集団を作成し、術式の違いが長期予後に与える影響を検討 した

【結果】腫瘍因子では AR 群はNAR 群と比䡴し、腫瘍径が有意に大きく、微小 脈管侵襲の割合が高かった。一方、背景肝機能ではNAR群はAR群と比較し、 有意にAlb 值が低く、ICGR15值が高く、血小板数が少なく、PT活性が低かっ た。手術因子では、AR群で手術時間が長く、出血量も多かった。PSマッチン グ、IPTWを用いて背景のそろった集団を作成し、長期予後を比較すると、 AR 群と NAR 群の予後に美はなかった。

【結語】単発5 $5 \mathrm{~cm}$ 以下のHCCに打いて術式は長期予後に影響しないと考元られ た。

PD05-5 肝細胞癌 ( $5 \mathrm{~cm}$ 以下、単発)における肝部分切 除術と亜区域切除術の選択に関する検討

九州大学 消化器・総合外科

伊藤心二, 吉住朋晴, 吉屋匠平, 長尾吉泰, 武石一樹, 戸島剛男, 原田昇, 池上徹, 森正樹

【はじめに】肝細胞癌において肝切除は有効な治療法として確 立されているが、肝予備能低下、腫瘍の位置、夲きさによって 带区域切除術を選択吉るか部分切除術を選択卞るか判断に苦慮 することがある。今回我々は肝部分切除術と亜区域切除術の長 期予後に関して検討を行った【対象・方法】2000年から2017 年までの初回肝細胞癌切除症例602症例中、単発で $5 \mathrm{~cm}$ 以下 病変に対して肝部分切除術 (PHx) もしくは带区域切除術 (AHx) を施行した268例を対象とした。1.術式別での臨床因子 の比較：PHx群184例と AHx 群84症例の 2 群で臨床因子小よび 予後の比較を行った2 傾向スコアを用いた解析：倾向スコア を用いて 2 群間での臨床因子および予後の比較を行つた。【結 果】1.PHx群で肝機能が有意に不良であった。腫瘍因子では PHx群で腫瘍径が小さく、病理学的脈管浸潤症例が少なかった。 無再発生存率および生存率は両群間で差はなかった。2. 術前因 子をマッチングさせたPHx 群67例、AHx群67例で解析を行っ た。AHx 群で病理学的脈管浸潤陽性症例が多かった。PHx群 で手術時間が短く、出血量も少なかった。切除断端距離に差は なかった $(\mathrm{p}=0.2506)$ 耐群間で無再発生存率 $(\mathrm{p}=0.2548)$ お よび生存率 $(\mathrm{p}=0.2499)$ に差はなかったが、術後 2 年以内再発 率 $(\mathrm{p}=0.0386)$ はP X 群で多かった。【結語】肝細胞癌におけ る肝部分切除術は症例に応じて有効な術式である。

PD05-6

慮した肝切除術 器外科学 和田浩志 ${ }^{1}$, 高橋秀典 ${ }^{1}$, 長谷川慎一郎 ${ }^{11}$, 小林省吾 ${ }^{1,2)}$, 飛鳥井慶1) 山田大作 ${ }^{12}$, 杉村啓二郎1), 山本和義1), 西村潤一1), 安井昌義 ${ }^{1)}$, 大森健 ${ }^{1)}$, 宮田博志 ${ }^{1)}$, 大植雅之 ${ }^{1)}$, 矢野雅彦 ${ }^{11}$, 左近賢人 ${ }^{11}$

系統的肝切除は，肝細胞癌が経門脈的に肝内転移をきたすという 概念に基づいて推奨されているがその有用性については一定の 結論には達していない。我々は, 腹部血管造影検查の肝動脈造影 CT (CTA) において, 腫瘍血流ドレナージ領域が描出され, この 領域が経門脈的局所転移の危除領域であることを報告してきた。 そこで肝細胞癌を腫醍血流動態により分類し、その特徵と系統的

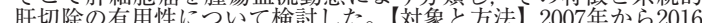
年までに肝切除術を施行した初発肝癌症例のうち, CTAを施行し た166例を対象とした。腫瘍濃染領域を, Marginal(M-type), Portal(P-type), Hepatic vein (HV type) の 3 群に分類して, 臨 床病理学的因子, 予後抒よび系統的肝切除の意義について比較検

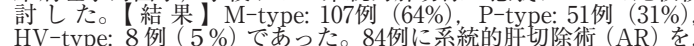
82 例に非系統的切除術 (NAR)を施行した。AR群と NAR群の 2 群間で, 無再発生存率, 全生存率に有意な差を認めなかった。腫 瘍濃染領域別の無再発生存率は, M-type と比較して, P-type, HV-typeが不良であったP-type51例では，AR(33例) の 3 年無 再発生存率は66\% と.NAR (18例) の33\%よりも良好な傾向であ つた $(\mathrm{P}=0.06)$ 【結語】肝細胞癌に対しては, 個々の症例におけ る腫瘍血流ドレナーシ領域を考慮した過不足のない肝切除術が重 要である。 
PD06-1

消化器外科領域における近未来のロボット支援

手術の位置づけ

岡山市立市民病院がん治療サポートセンター

大村泰之

ロボット支援手術は、医学・工学、医療政策・経済的側面が複 雑に関与した医療分野で、手術時間やコス卜、人材活用など多 くの因子を踏まえ理想的な位置づけを検討する必要がある。客 観的な評価がなされた臨床試験では、腹腔鏡下手術と比較して コストに見合う優越性はない。ロボット技術の導入は、腹腔鏡 アームのみをロボット技術で操作するロボティックスコープホ ルダー (RSH) から始まった。新しいRSHに関して、満足度 の高さや手術時間の短縮、人材削減などが報告されている。当 院でも2014年12月より RSHを導入し、待機・緊急手術に関わ らず使用している。術者の作業空間が制限されない、術者の意 思で術野確保が可能である、カメラ污染が少ない、導入費用が 比較的安いなどの利点がある。また手術を行うに必要な外科医 数の削滅が出来ることは、外科医の減少、また「医師の働き方

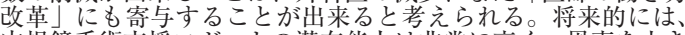
内視鏡手術支援口ボットの潜在能力は非常に高く、恩恵を大き く受ける時代が来るだろうが、近未来の外科手術像として、長 時間の複雑な手術で術者に良好な手術環境を提供する目的で使 用し、虫垂切除、胆摘、ヘルニア手術、さらに緊急手術まで適 応とすることは現害的ではないと考える。一方でRSHの役割 を正当に評価することが必要と考える。過去の消化器外科手術 に拈けるロボット支援手術の臨床試験デー夕と当院での成績を まとめ報告する。

PD06-2

高難度胃癌手術におけるロボット支援手術の有

用性

日本赤十字社和歌山医療センター 消化管外科

辰林太一,山下好人, 上野剛平, 山口賢二, 宮本匠, 榎木佑弥, 野間淳之, 山田真規, 細川慎一, 横山智至, 米永吉邦, 伊東大輔, 一宮正人, 安近健太郎, 宇山志朗

(背景と目的) ロボット支援下胃切除 $(R G)$ は腹肛鏡下胃切除 $(L G)$ に比べ手術時間は長いが,腹垫内感染性合併症 (IAIC) は少ない 可能性がある.RGの最大のメリットは関節機能を持つ鉗子による 精巧な操作にあると考え,より進行した癌や TG/PGなどの高難度 手術に対して有用性があると考えている.当院では再建も含め, 助 手の鉗子操作に頼らない solo surgeryで行って扔り, 関節機能を活 用するためLCSは用いず,モノポーラシザースでソフト凝固/ブレ シドカットを使い分けて使用することで,安全から精緻なリンパ節 郭清を行っている.当院での RGの手技の染イントと,有用性/安全 性についてLGと比較した短期成績を示し検討する. (対象と方法) 2017.3 20195に初登胃㿋に対LR0切除老行った255例が対象当 院では全胃癌手術を鏡視下に施行している.短期成績を術式毎に LG と比較した。(結果) LG198例,RG57例.LG对 RG で, 手術時 間:323/406分,出血量: $55.8 / 22.7 \mathrm{~g}$,Clavien-Dindo (CD) 分類 Grade3 以上の IAIC: $10 / 1$ 例.DG150例 中 cStage IIA 以上の DG は61例 で,LG47例/RG14例, 手術時間: 364/385分,CD3以上のIAIC: $3 / 0$ 例 $\mathrm{PG}$ は41例 IAIC: $0 / 1$ 例 (3a).TG は28例で,LTG19例/RTG9例. 出 血 量:128/55g,CD3以上の IAIC: 0 / 0 例。(結語) RGは全体として手 術時間は延長するが出血量は少ない傾向があり,IAICの頻度につ いては同等であった.当院の RGの手技は高難度胃癌手術に詨して も有用である可能性が示唆された。

PD06-3

上部消化管外科領域におけるロボット手術

北里大学 上部消化管外科

細田桂, 添野孝文, 原苗宏輝, 鷲尾真理愛, 櫻谷美貴子, 牛久秀樹, 新原正大, 山下継史, 比企直樹

目的上部消化管外科領域におけるロボット手術の成績からロボ ット手術の位置づけについて考察する。方法2019年 5 月までに 施行した上部消化管癌に対するロボット手術を対象とし、手術 成綪を検討した。胃切除では右手デバイスをバイポーラーメリ 一ラシドと超音波切開凝固装置とし、食道切除では胸部操作の み腹卧位でロボットを使用し右手デバイスをモノポーラーシザ ーズとした。結果67例の胃切除術と 5 例の食道切除を施行した。 患者背景は、胃; 食道切除それぞれ年齢70;67歳（以下寸べて 中央値)、男性 $51 ; 4$ 例。術式は食道要全摘 (MIE) / 幽門側 胃切除 (DG) / 胃全摘術 (TG) / 噴門側胃切除 (PG) $5 / 46 / 11 / 10$ 例、コンソール時間はMIE/DG/TG/PG 219/274/336/285.5分、 全手術時間は494/316.5/364/365分であった。出血量はMIE (胸 部操作のみ) $/ \mathrm{DG} / \mathrm{TG} / \mathrm{PG}$ 少量 $/ 22 / 65.5 / 70 \mathrm{ml}$ 、郭清リンパ節 個数はMIE (胸部操作のみ) /DG/TG/PG 15.5/37/54/28個、術 後在院日数は MIE/DG/TG/PG 21.5/7.5/8/9日であった。 Clavien-Dindo grade III 以上 $の$ 合併症は、綘合不全 3 例（MIE 2 例、DG1例) と吻合部㹨窄 5 例 (PGのみ) であった。 MIE においては反回神経麻痺を認めなかった。結論胃切除における ロボット手術は膵上縁郭清・縫合結棌手技において威力を発揮 する。食道切除におけるロボット手術は出血量の減少と反回神 経麻疩の低減がメリットである。より安価な器機の開発があれ ば、ロボット手術は従来型内視鏡手術にとって代わる可能性が ある。
PD06-4 胃癌・食道胃接合部癌領域におけるロボット支 援手術にかける嘱望

名古屋市立大学 消化器外科

佐川弘之, 小川了, 早川俊輔, 藤幡士郎, 中屋誠一, 大久保友貴, 田中達也，高橋広城，松尾洋一，瀧口修司

腹腔鏡手術における技術・器械が進歩し, 定形化が進んだ結果, 進行癌に対しても晏全に施行し得ることが示されつらある.腹 腔鏡手術は，低侵襲性をもたらしたが，当科では、ロボット手 術のさらなる利点がその「安全性」にあると強い信念を持って いる.腹腔鏡手術では十分な結果が得られない難易度が高い術 前化学療法後や食道胃接合部癌, 残胃癌症例に対して確実な解 剖理解, 手術のコンセプトを理解することでより高いパフォー マンスにつな゙ると考える。当科では，2018年 3 月から胃癌に 対しロボット支援手術を導入し2019年 7 月までに104症例を施 行してきた。 气のうち術前化学療法後症例 : 6 症例, 食道胃接 合部癌症例： 5 症例, 喷門側胃切除症例： 2 症例が含まれる。 今回，同疾患の手技を供覧し、胃領域におけるロボット支援手 術の位置づけを考える。多関節機能により組織のアプローチ法 の選択肢が増え, motion scale, 手ぶれ防止機構により緻密な 操作をもたらした。加えて高拡大 $3 \mathrm{D} H \mathrm{HD}$ 画像により解剖認識 能力の向上が手術のクオリティーに繋がることは疑い上うがな いと考える。特に食道胃接合部癌に抢ける縦隔内の高い位置で の再建ではブレのない視野展開がもたらす効果は大きい。高コ ストやセッティング時間, 操作範囲の狭さによるカメラワーク 鉗子のシャフトの高い空間把握能力など将来にわたって改善す 今゙き点はあるが, ロボット手術のもたらしうる可能性に期待し ている。

\section{PD06-5}

胃癌に対するロボット支援胃切除：腹腔鏡手術

静岡がんセンター 胃外科 ${ }^{1)}$, 静岡がんセンター 消化器外科 ${ }^{2}$ 寺島雅典 ${ }^{1}$, 日景允 ${ }^{1}$, 藤谷督—1), 古川健一朗 ${ }^{11}$, 神谷諭 ${ }^{11}$, 谷澤豊1), 坂東悦郎1 ${ }^{1}$, 塭見明生 ${ }^{2)}$, 杉浦禎一2)

【はじめに】胃癌に対するロボット支援手術（RG）は、新たな 低侵襲手術法として注目されているが、腹腔鏡下胃切除 (LG) に対多る優越性は示されていない。RGの有用性を検索する目 的で、腹腥鏡下胃切除 (LG) と比較検討した。【方法】2012年 1月から2018年12月までに、cStage I, II に対して当科で手術 が施行されたRG281例、LG723例から、年齢、性別、ASAPS、cStage、術式を共変量として Propensity score matching により RG279例、LG279例を選択し、短期、中期成績を比較し た。【結果】 RGでは手術時間が有意に延長していた（324分vs 283分 $\mathrm{p}<0.001)$ が、出血量、郭清リンパ個数には有意な差 を認めなかった。CD分類 II 以上の術後合併症の発生率はRG $15.0 \%$ 、LG $19.0 \%$ で有意な差を認めなかった。但し、第 1 病日 のドレーン AMY (758 vs 629) はRGが有意に低值を示してい た。 5 年全生存率は RG97.4\%、LG93.5\% で、RGで良好な傾向 を示したが有意な差は認められなかった $(\mathrm{p}=0.111)$ 【結語】 ロボット支援下胃切除は導入早期にも係わらず腹腔鏡下胃切除 と同等の安全性と有効性を示していた。術後アミラーゼが低估 を示していることから、膵蔵に対してより低侵襲である事が示 唆された。今後、前向きの比較試験によりロボット支援下胃切 除の有用性を検証すべきと思われる。

PD06-6 直腸癌に対するロボット支援手術の有用性 High Volume Centerでの経験を生かした市中病院での導入と 短期成績

卜当夕記念病院 消化器外科

山川雄士, 春木伸裕, 只原裕樹, 越智靖夫, 加藤知克, 原田真之資, 藤田康平, 津本知沙, 箫田憲幸, 辻秀樹

ロボット支援手術は、従来の腹腔鏡手術において難易度が高いとされ る直腸癌手術においても、解剖学的構造に沿った繊細で正確な手術が 可能となり、有用なデバイスと考える。演者は静岡がんセンター (SCC) でロボット支援下直腸癌手術を経験 L、ヨ夕記念病院 (TMH) ロボット支援手術を導入した。その経験と短期成績を報告する。目的】 SCCとTMHでの䉓一術者によるロボット支援下䋶を腸癌手術の。短期成 績を明らかにすること。【対象】2017年8月から 8 月傜手術の短期成 SCCでのロボット支援下直腸癌手術41例と、2019年5月から2019年 8 月までの TMH での12例の計53例。【結果】主占居部位 (RS/Ra/RbP) はSCC 10/19/12例、TMH $3 / 3 / 6$ 例。術式 (LAR/ISR/APR) は SCC 32/4/5例、TMH 11/0/1 例。総手術時間（側方郭清非施行例） SCC/TMH 260 (116-451) /198 (136-310) 分。手術開始からロボッ トのDockingまでの時間 SCC/TMH 21 (11-46)/25 (19-45) 分 ( $\mathrm{P}=0.04)$ 上腹部操作時間 SCC/TMH 61 (35-121) / $/ 50$ (35-66) 分

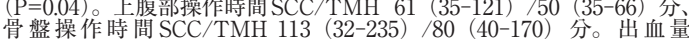
SCC/TMH $7(0-383) / 15(2-527)$ ml。一時的人工肛門造設率 (LAR のみ) SCC/TMH 15.6/0\%。術後在院日数 SCC/TMH 7 (6-12) 7 日 $(6-10)$ 。SCC と TMH \%全症例で開腹移行を認めず、ClavienDindo 分類Grade3以上の術後合併症は認めなかった。 全症例でR0切 除が達成できた。【考察】ロボット支援下直腸癌手術は市中病院にお いても安全に導入でき、優れた短期成績を示した。 
PD06-7

直腸癌肥満症例に対するロボット支援手術の短

期成績

千葉西総合病院 外科

小林昭広, 山崎信義, 久保浩一郎, 小林亮介, 森本善博, 浅井大智, 赤嶺洸太，山田典子，柿本應貴，緒方賢司

【はじめに】狭い空間での操作が必要となる直腸癌手術では、 多関節鉏子・手振れ防止機構・3Dが備わったロボット支援手 術が有用である可能性がある。今まで手術難易度が高かうた男 性・狭骨盤・肥満・縫合を要する症例での治療成績向上に期待 している。2018年 4 月よりロボット手術を導入し肥満症例で術 者ストレスが軽減していると感じたためその短期成績を評価す る。【対象】2019年 6 月までの直腸癌に対するロボット支援手 術50例中 BMI が25以上の17例 $(34 \%)$ 【結果】男性12例、女 性 5 例。手術時間中央值219分 (145-399分)、出血量中央值 $25 \mathrm{ml}(17-100 \mathrm{ml})$ 。術後入院期間中央值 12 日 $(7-68$ 日)。開腹 移行 $0 \%$ 。術後合併症 (Clavien-Dindo 分類 IIIb 以上) 1 例 (縫 合不全でストーマ造設)。【症例 1】10例目：73歳女性、 BMI30,Rb, cT1bN0M0、手術時間217分。【症例 2】33例目: 58 歳女性、BMI33.2、Ra、腫瘍の大きさ1 cm、cT3N0M0、手術 時間307分。【症例 2】46例目：57歳男性、BMI29.4、Ra, cT3NOM0、手術時間204分。【手術手技のポイント】1) 左側展 開などで右側ハサミの操作制限が強い場合は左手に交換する 2) 巨大腫瘍や小腸落ち込み時の視野確保目的に右側腹部に $5 \mathrm{~mm}$ 助手ポートを 1 本追加する。【考察】ロボット導入初期の 段階であるが肥満症例でも安全に手術が行えていた。【おわり に】症例の蓄積によりさらなる成績向上が期待される。

PD06-8 東京大学腫瘍外科

直腸ロボット手術における術後排尿機能の評価 川合一茂, 平田悠悟, 福井梨紗, 野澤宏彰, 畑啓介, 田中敏明, 石原聡一郎

背景・目的）直腸癌に対するロボット手術では精密な術操作に よる機能温存が期待されるが、ROLARR試験では尿路合併症 の率に腹腔鏡と差がなかった。直腸癌に対する腹䏶鏡手術と口 ボット手術において術後の排尿機能を比較する前向き試験を行 った。対象・方法）2013年5月から2018年10月までにRbにか かる直腸癌に対し腹腔鏡手術又はロボット手術を施行した299 例のうち、術前・術後1 万月に国際前立腺症状スコア (IPSS) にて排尿機能を評価し得た205例を対象とし、IPSSに影響を与 える因子につき検討した。結果) 術前治療として化学放射線療 法（CRT）が38.3\%施行されていた。術式はAPR/CAA/ISR/ LARが各々 $5.7 \% 、 8.3 \% 、 20.1 \% 、 65.9 \%$ であ、8.7\%で片側 $13.3 \%$ で両側の側方郭清が併施されていた。開腹移行は腹腔鏡 群145例中 4 例、ロボット群60例ではなかった。ロボット群と 腹腔鏡群の術前 IPSS スコアは各々中央值 4（）-35）、4（0 -35) であり有意差なく $(\mathrm{p}=0.981)$ 、術後 $1 \mathrm{M}$ の IPSS も各々 6（0 -35)、6 ( 0 - 35$)$ で差がなかった $(\mathrm{p}=0.713)$ 。多変量解析では、 術前の高IPSSに関与する因子は高齢、男性、T3以深であった。 一方術後の高IPSSに関与する因子は高齢、術前IPSS高値（10 以上）であり、術前の排尿状態の影響が大きい一方で、CRT の有無や側方郭清、ロボット手術か否かは術後のIPSSへの影 響は比較的小さからた。結論) 直腸癌手術におけるロボット手 術の腹腔鏡手術の排尿機能に対する優越性は示されなかった。

PD06-9 大腸がんにおけるロボット支援手術の位置づけ 大阪大学 消化器外科 1 , 九州大学 消化器・総合外科2 松田宙 ${ }^{1)}$, 荻野崇之 ${ }^{1)}$, 三吉範克 ${ }^{1)}$, 高橋秀和 ${ }^{1)}$, 植村守 ${ }^{1)}$, 水島恒和 ${ }^{1)}$, 山本浩文 ${ }^{1)}$, 森正樹 2 , , 土岐祐一郎 ${ }^{11}$

2018年 4 月から消化器外科領域の食道癌, 胃癌, 直腸癌に対する ロボット手術が保険収載となり,急速に普及している。ロボッ 下手術は安定した3D画像の下,手振れのない多関節機能を有し た鉗子操作により，理想とする精緻な手術をより容易に行うこ とが可能となった。また腹腔鏡手術で問題となる鉗子の可動制 限のため手術困難な症例において、さらにロボット手術は有效 である。一方、手術時間はかかるものの未だ明らかな優越性は

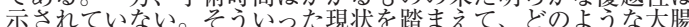
癌に対してロボット手術を取り达むのかが課題である。当科の 現状を紹介するとともに、今後の展望について発表する。
PD06-10 下部消化管領域におけるロボット手術 東京医科歯科大学 消化管外科

絹笠祐介, 松山貴俊, 菊池章史, 山内慎一, 馬場裕信, 高岡亜弓, 松宮由利子, 青柳康子, 山本雄大, 茂原富美, 笠并俊介, 田澤美也子，山下大和，塩原寬之，徳永正則

ロボット支援下大腸手術は、保険収載をされた後は、これまで の 3 倍以上となる月 100 例ほどの手術件数となって以降、増加 の一途をたどっている。欧米では直腸がんのみならず、結腸癌 に対するロボット手術も盛んに行われているが、本邦ではほと んどが直腸癌である。直腸癌におけるロボット手術は国際的に は普及し、安全性に関守る報告は多いが、有効性に関守るデー 夕はまだ十分ではない。ロボット手術では、尿失禁が腹腔鏡手 術と比較して改善するとの報告がある一方で、差がないとする 報告もある。性機能に関する報告の多くでは、ロボット手術で 良好な成績が報告されている。ROLARR 試験では主要評価項 目は開腹移行率であり、腹腔鏡下手術群 $12.2 \%$ 、ロボット手術 群 $8.1 \%$ であり、統計的有意差は認めず、ロボット手術の優越 性を示すことをできなかった。一方で、静岡がんセンターにて 600例のロボット直腸がん手術の治療成績を検討すると、ロボ ットを使用することによって、開腹移行率、出血量、術後排尿 障害の減少を認め、下部進行直腸癌では予後の改善も認めた。 現在、当科では直腸がん手術は全例ロボット手術で施行されて おり、結腸がんに対しても自由診療のもとロボット手術を導入 している。今後の課題として、指導医の育成ならびに安全な普 及、技術認定医や施設基準の問題、そして結腸がんに対守るロ ボット手術の保険収載が挙げられる。

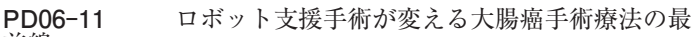 \\ 前線}

札棍医科大学 消化器 · 総合、乳腺 · 内分泌外科学講座

竹政伊知朗, 沖田憲司, 西舘敏彦, 奥谷浩一, 碓井彰大, 秋月恵美, 浜部敦史, 石井雅之, 里吉哲太

直腸癌に対するに対する外科治療は、TMEを基本として、 CRM/DRM 陰性を確保することで、優れた短期成績だけでな く長期予後でも良好な成績が期待される。近年、直腸癌領域で は腹腔鏡手術が低侵襲性と根治性に加え機能温存の面でも急速 に普及してきたが、最近の国際的第 III相試験では根治性に関 し開腹手術に対する非劣性は証明できていない。これは通常の 直線的な腹腔鏡機器を用いた骨盤内操作が依然として高難度で あることを示している。この問題点に対して、ロボット支援手 術とtaTMEが注目を集めている。しかし、いずれの術式も成 熟課程であることに加え技術的なピットフォールがあり、通常 の腹腔鏡に対してCRMを endpointとした有用性は、未だ確立 されていない状況である。われわれは2013年にロボット支援手 術を、2014年にtaTMEを導入し、それぞれ100例以上の症例を 重ねてきた。2016年にはロボットを経肛門的に操作し、元つの 術式を融合することで直腸癌をより精緻に切除する手技を国内 で初めて施行し、さらには2017年から fresh cadaverを用いて 最新式のロボット機器を経肛門的に応用した手技の開発に取り 組んでいる。本邦でのロボット手術に対古る保険収載は、大腸 癌領域では直腸癌に対して2018年に開始されたが、さらなる適 応桩大を目的として、2019年より結腸癌に対するロボット手術 の全国的な臨床試験も開始され結果が待たれる。

ガイドライン適応の観占からみた肝細胞癌に対 する開腹肝切除と腹腔鏡肝切除の治療成績の比較 山口大学大学院 消化器. 腫瘍外科学 1 , 山口大学医学部附属 病院腫瘍センター2), 山口大学医学部先端がん治療開発 学 ${ }^{3}$. 川崎医科大学 消化器外科 4

德光幸生 ${ }^{1)}$, 新藤芳太郎 1 1), 松井洋人 ${ }^{1)}$, 松隈聰 1$)$, 中島正夫 ${ }^{1)}$, 兼清信介1 ${ }^{\prime}$, 友近忍 ${ }^{1)}$, 吉田晋1), 飯田通久 ${ }^{1)}$, 鈴木伸明 ${ }^{1)}$, 武田茂 ${ }^{1}$, 吉野茂文 ${ }^{2}$, 硲彰一 3 , , 上野富雄 ${ }^{4}$, 永野浩昭 ${ }^{1}$

【背景】 2017 年版肝癌診療ガイドラインの腹腔鏡手術の推奨「部分切 除や外側区域切除が可能な肝前下領域 $(\mathrm{S} 2-6)$ の末梢に存在子る $5 \mathrm{~cm}$ 以下の単発腫瘍」の観点から当科の肝細胞癌に対する肝切除の治 療成績を検討した。【対象】2002年〜2018年に3 個以内の肝細胞癌に 対し初回肝切除を行った227症例を、ガイドライン推奨適応条件（推 奨例) と推奨商応外条件 (非推奨例) 分けて、腹脘鏡 $(\mathrm{L})$ 群と開腹 $(\mathrm{O})$ 群の治療成績を比較検討した。【結果】推奨例は37例 (L:26例、O:11例) と、非推蒋例は190例 (L:56例、O:134例) であった。推奨例では手術 時間 (中央值) [L:251分、O:275分] で差はなく、出血量 (中央值) [L:20ml、 $0.255 \mathrm{ml}$ [有意差にL群で有意に少なかった $(\mathrm{p}<0.05)$ また、術 $\mathrm{O}: 255 \mathrm{ml}]$ は有意差にL群で有意に少なかった $(\mathrm{p}<0.05)$ また、術
後合併症 (有/無) [L: $3 / 23 、 \mathrm{O}: 4 / 7$ は $\mathrm{L}$ 群で少ない傾向 $(\mathrm{p}=0.08)$ 後合併症 (有/無) [L:3/23、O: 4/7] は L群で少ない傾向 $(\mathrm{p}=0.08)$

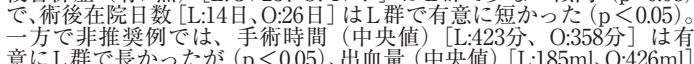
に差は認めなかった。また、術後合併症Clavien-Dindo grade3以上(有) 無) [L:11/45、O:38/96] に差はなかったが、術後在院日数 [L:13日、O:22

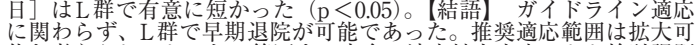
能と考えられるが、どの範囲まで安全に適応拡大出来るかが検討課題 である。 
vs 鏡視下)

関西労災病院 外科

大村仁昭, 武田裕, 桂宜輝, 阪本卓也, 中平伸, 河合賢二

柳川雄大, 柳井亜矢子, 村上剛平, 賀川義規, 益澤徹, 竹野淳, 畑泰司, 柄川千代美, 村田幸平

【目的】腹胫鏡下肝切除術は低侵襲性と整容性に優れ、多数の施設 で施行されてきている。当院での肝細菢癌に対多る腹腔鏡下肝切 除の成績を検討した【対象と方法】2010年 6 月から2018年 9 月ま でに312例の肝細胞癌に腹腔鏡下肝切除を施行。2004年 1 月から 2018年 9 月に施行した開腹肝切除症例126例と比較検討。腹䏦鏡下 肝切・開腹肝切は、年齢70.7 68.2 歳 (ns)、男女 $209 / 103 \cdot 101 / 25$ (ns)、Child-Pugh $(\mathrm{A} / \mathrm{B} / \mathrm{C}) 2292 / 20 / 0 \cdot 117 / 9 / 0$ (ns)、肝障害 度 $(\mathrm{A} / \mathrm{B} / \mathrm{C}) 224 / 86 / 2 \cdot 90 / 36 / 0$ (ns)、Stage (I/II/III/IV) $76 / 115 / 43 / 16 \cdot 18 / 43 / 32 / 16(\mathrm{p}<0.001)$ 【結果】 腹䏕鏡下肝切. 開腹肝切は、手術時間 $339 \cdot 247$ 分 $(\mathrm{p}<0.001)$ 、出血量 $337 \cdot 1456 \mathrm{~g}$ $(\mathrm{p}<0.001)$ 、術後在院日数 $15.7 \cdot 16.6$ 日 $(\mathrm{ns})$ 、第 1 病日 AST $526 \cdot 460 \mathrm{IU} / \mathrm{l}(\mathrm{ns}) 、$ ALT $356 \cdot 336 \mathrm{IU} / \mathrm{l}(\mathrm{ns}) 、 \mathrm{~T}-\mathrm{Bil} 0.95 \cdot 1.33 \mathrm{mg} /$ $\mathrm{dl}(\mathrm{p}<0.001) 、$ WBC $9674 \cdot 11378 / \mu \mathrm{l}(\mathrm{p}<0.001)$ 、 CRP 1.43 . $2.78 \mathrm{mg} / \mathrm{dl}(\mathrm{p}<0.001)$ 。術後出血 3 - 5 例 $(\mathrm{ns})$ 、胆汁漏11 5 例 (ns)、 3 年無再発生存率は腹腔鏡下肝切・開腹肝切が、StageI $43.4 \cdot 26.8 \%$ (ns), StageII $48.2 \cdot 40.9 \%$ (ns), StageIII $43.5 \cdot 8.7 \%$ $(\mathrm{p}=0.035) 、$ StageIVA $26.7 \cdot 14.0 \%(\mathrm{~ns}) 。 3$ 年全生存率は腹腔鏡 下肝切・開腹肝切は、StageI 85.0 - 70.6\% (ns)、StageII 87.1. $90.0 \%$ (ns), StageIII $61.5 \cdot 69.0 \%$ (ns) 、StageIVA $26.3 \cdot 36.9 \%$ (ns)。 【考察】開腹肝切除に比べ腹腔鏡下肝切除は、手術時間を要したが 出血量は少なく低侵襲であり、長期成績も同等であった。

\section{PD07-3}

肝細胞癌に対する腹腔鏡下肝切除と術後腹腔内

感染症の関連

大阪市立大学大学院 盰胆膵外科学

新川寬三, 田中肖吾, 竹村茂一, 天野良亮, 木村健二郎, 山添定明, 大平豪, 西岡孝芳, 田内潤, 宮崎徹, 石原敦, 江口真平, 白井大介, 久保正二

【目的】肝細胞癌に対する腹䐑鏡下肝切除術と術後腹泻内感染との 関連について検討した。【対象·方法】2008年 1月〜2018年 6 月 に腫瘍サイズ $5 \mathrm{~cm}$ 以下の肉眼的脈管侵襲を伴わない肝細胞癌初回 肝切除384例を対象とした。腹脘鏡下肝切除(Lap 群) は206例 (pure:166例、Lap-assist:36例、 HALS: 4 例)、開腹下肝切除 (Open 群)は178例であった。術後合併症率 (Clavien-Dindo $\geq 2$ ) につ いてPropensity score matching(PSM) を用いて比較した。サブ グルーブ解析として横隔膜下 (S7,8) と非横隔膜下 (s7,8以外)に 分類し検討した。検討項目は性別、年齢 $>65$ 墄、BMI $\geq 25$ 、糖尿病、 $\mathrm{ASA} \geq 3$ 、ウイルス性肝炎、ALT $>30 \mathrm{IU} / 1$ 、 Plt $<10$ 万 / $\mu \mathrm{l}$ 、 AFP $>20 \mathrm{ng} / \mathrm{ml} 、 2$ 区域以上切除、Child-Pugh 分類、多発腫境、 腫境サイズ $>2 \mathrm{~cm}$ 、主要脈管への近接、difficult location $(\mathrm{S} 7,8,4 \mathrm{~b})$ とした。【結果】PSM後は蚺群の背景因子に有意差を認めなかった。 Lap 群 $(\mathrm{n}=128)$ はOpen群 $(\mathrm{n}=128)$ と比べて術後合併症率 $(11.7 \%$ vs. $31.2 \%, \mathrm{p}<0.001)$ 、腹腜内感染症発生率 $(0.8 \%$ vs. $7.8 \%$, $\mathrm{p}=0.010$ )、胆汁漏発生率 ( $0 \%$ vs. $6.2 \%, \mathrm{p}<0.001)$ が低かった。 横隔膜下腫瘍でLap 群はOpen群と比べて腹脘内感染症発生率( 0 $\%$ vs. $15.9 \%, p=0.0056)$, 胆汁漏発生率 ( $0 \%$ vs. $6.2 \%, p<0.001)$ が低かったが、非横隔膜下腫瘍では両群間に有意差を認めなかっ た。【結論】肝細胞癌に対する腹垫鏡下肝切除術は特に横隔膜下腫 瘍に対して腹腔内感染症を減少させる可能性が示唆された。
PD07-5 高度肝硬変患者に対する腹腔鏡下表在肝切除打 よび再発肝腫瘍に対する腹腔鏡下肝再切除 藤田医科大学医学部一般外科学講座 ${ }^{1)}$, 藤田医科大学ばんた 权病院 消化器外科学講座 2 (2)

守瀬善一1), 浅野之夫2), 堀口明彦2)

腹腔鏡下肝切除 $(\mathrm{LLR})$ では腹腔鏡と鉗子が横隔膜下哚に直接 access し肝周囲環境破壊を最小化した切除が可能となる。肝表 面腫瘍切除では機能肝切除量は最小限で"手術侵襲自体への耐 術"が問題となり、LLR 適応基準独自検討が必要である。再肝 切除では“癒着間に鉗子が侵入し working spaceが確保できれ ば全面剥離が必須でない”利点がある。LLR中ICG30\%超23例、 再肝切除39例、3 回以上切除12例を経験した。Child Pugh (CP) class と肝障害度には乘離があり、最小限間膜切離・Pringle 非 施行 - 局所操作のみ肝表面 LLRを、軽作業継続従事可能PS $\mathrm{CP}-\mathrm{B} / \mathrm{C}($ score $\leqq 10)$ 13例に適応し、軽-中等度障害例と同等 の短期成績だった。24月超経過 ICG30\%超17例中 7 例が 24 月内 に癌・肝不全死したが、24月以上生存例と比較すると CP scoreに有意差を認めた。初回:再切除: 3 回以上例の手術時間、 出血量、在院日数、conversion、合併症は有意差がなかった。 ICGは肝切除量・侵襲を限界まで低減した肝表面LLRの適応 基準となり難いが、CP scoreはPS予後と相関があり良い指標 となり得る。再肝切除は周術期経過が初回と同等であったが、 初回、再肝切除とも肝門部㐌リソン剥離操作を行った症例では 合併症と在院日数延長を経験しており注意を要する。国際肝臓 内視鏡外科学会で行ったHCC再肝切除1582例の国際PSM研究 ではLLRは開腹と短長期成績が同等で、慢性肝疾患背景 HCC で治療体系中の肝切除の位置づけを変える可能性がある。

\section{PD07-6 \\ 肥満症例に対する腹腔鏡下肝切除術の安全性の \\ 佐賀県医療センター好生館 \\ 篤}

肥満症例に対する腹腔鏡下肝切除術に関する安全性に関して は、十分なエビデンスがない。今回、肥満症例に対する腹腔鏡 下肝切除の安全性について検討を行った。2013年から当科で㖃 切除を施行した253例を対象とし、後ろ向き検討を行った。検 討 1 : 全253例中に肥満症例 (BMI 25) は88例であった。そ の中で部分切除を施行した55例を腹腔鏡症例 43例（Lap Hr0 群)、開腹症例12例（Open Hr0群）に分け比較検討した。両群 間の背景に差は認めなかったが、Lap HrO群で有意に出血量が 少なく、合併症が少なかった。検討 2 : 全253例中、腹腔鏡症 例156例を肥満症例57例 (Lap Obese群) と非肥満症例96例 (Lap Non-Obese群) に分けて検討を行った。両群間の背景に差孝 認めなかったが、Lap Obese群では有意に手術時間が長く、出 血量が多かったが。術後合併症には差がなかった。検討 3 : 腹 㬶鏡で施行した肥満症例57例の手術時間、出血量に関連する因 子について検討した。腫瘍径が大きく、系統的肝切除を施行し た症例で手術時間が有意に長く、出血量が多かった。結語：肥 満症例に対する腹腔鏡下肝切除術は開腹と比較し安全である。 非肥満例と比較しても合併症は変わらず安全ではあるが、系統 的切除や腫瘍径が大きい症例では出血量が多く、さらなる工夫 も必要と考えられた。

PD07-7 肥満合併肝細胞癌における腹腔鏡アプローチの 㤫用京性科歯科大学 肝胆膵外科 ${ }^{1)}$ ，東京医科歯科大学 分子腫 陽医学 2

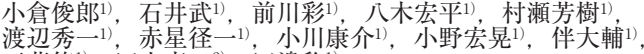
工藤篤 ${ }^{11}$, 田中真二 ${ }^{2}$, 田邊稔 ${ }^{1}$ 【緒言】近年 $\mathrm{HCV}$ 関連肝癌が減少する一方、非ウイルス性肝癌
の堛加が報告されている。背景とした肥 満を有する肝細胞癌患者に対する治療が問題となる。一般に肥満 群に対与る外科的治療の周術期成績は非肥満群と比較し不良とさ れるが、近年の発展著しい腹脉鏡手術による肥満群に対する周術 期成績向上の可能性を検討した。【対象と方法】2005年から2018年 までに当科に扔いて肝細胞癌に対する肝切除を行った616例につ いて、手術 (Open 群) と腹垫鏡手術 (Lap 群) に分けて後方視的に検討 した。【結果】Underweight $(\mathrm{BMI}<18.5)$ 39例、Normal range $(18.5$ $\leqq \mathrm{BMI}<25)$ 377例、Overweight/Obesity $(25.0 \leqq \mathrm{BMI}) 200$ 例 て あった。Open群503例、Lap 群113例であり、両群間において肥満 度の分布に偏りは認めなかった。Open群は高BMI となるにつれ 出血量が増加し $(\mathrm{p}=0.026)$ 、手術時間が延長した $(\mathrm{p}=0.006)$ 。 Lap群は各BMI間で出血量と手術時間に差を認めなかった。また、 Open群とLap群ともにBMIによる術後合併症率と術後在院期間 に差を認めなかった。Open群とLap 群の比較では、術式によらず Lap 群で有意に出血量と合併症が少なく、術後在院日数が短く、 手術時間は同等であった。結語】腹胿鏡手術はBMIに影響を受 けずに良好な周術期成績であった。腹腔鏡アプローチにより、高 BMI肝細胞患者に扔ける手術困難性を克服しうると考えられた。 
PD07-8

80歳以上の超高齢者における腹腔鏡下肝切除術 の有用性・安全性について（開腹手術との比較検討）

昭和大学 消化器. 一般外科

草野智二, 青木武士, 山崎達也, 平井隆仁, 冨岡幸大, 柴田英貴, 和田友祐, 箱崎智樹, 野垣航二, 松田和広, 山田宏輔, 古泉友丈, 三田村圭太郎, 藤森聰, 村上雅彦

緒言) 近年の高齢化社会に伴い、その手術機会も増加してい る。高齢者は心肺腎機能の低下に加え、並存疾患を伴うことが 多く、術後回復が遅延する他、術後合併症が問題となり、全身 状態やADLを考慮した術式選択が望まれる。目的) 80歳以 上の超高歯者において、腹腔鏡下肝切除症例と開腹手術を比較 検討し、腹望鏡下手術の有用性 ·安全性を検証することを目的 とした。対象・方法）1998年1月から2018年12月において 当院にて施行された 80 歳以上の超高齢者肝切除症例 68 例を、腹 腔鏡群 (L群 : 22例) と開腹群 (O群：46例) に分け、手術成 績を比較検討した。結果) L 群 vs O 群を比較した結果、平均 年歯はそれぞれ83.5歳 vs82.6歳 $(\mathrm{p}=0.13)$ で、90歳上の症例は 認めなかった。また、術前並存疾患症例含め、患者背景・腫瘍 因子・術式に有意な差は無かった。手術成績は、手術時間 (210 vs $267 \mathrm{~min} ; \mathrm{p}<0.05$ ) および出血量 $(122.4$ vs $434.7 \mathrm{ml} ; \mathrm{p}<0.05$ において、L群で有意に良好な結果であった。また、術後合併 症 (Clavien-Dindo Grade3a 以上) は、31.8 vs 30.4\%（p=0.44) と有意差は認めなかったが、術後在院日数は、13.9 vs 22. 日 (p <0.05) と、L群で有意に短い結果であった。結語）慎重な 症例の選択が必要であるものの、腹腔鏡下肝切除術は、超高齢 者に㧧ても、比較的安全に施可能な有用な術式であることが 示唆された。

PD07-9 肝細胞癌に対する ICG 蛍光法を用いた系統的肝 切除術

東京大学肝胆膵外科

國土貴嗣, 石沢武彰, 渡邊元己, 真木治文, 市田晃彦, 金子順一, 赤松延久, 有田淳一, 長谷川潔

背景: 肝細胞癌に対する外科的切除では系統的肝切除術が推奖 されている。しかしながら、従来の染色法での系統的肝切除は 領域の同定が特に再肝切除症例などは難しいことが多い。一方 で、ICGを用いた染色法は微量のICGを門脈に注入することで 明瞭に境界を同定することが可能である。方法:当院において 2018年 4 月-2019年 3 月に肝細胞癌に対して肝切除術を施行し た51例を対象として検討を行った。そのうち腹腔鏡下肝切除は 11例、残りの40例は開腹肝切除であった。ICGを用いた染色法 により系統的肝切除を行った症例は11例であり、うち 2 例は腹 腔鏡下に施行した。結果: 超音波ガイド下に穿刺を行い、イン ジゴカルミン $5 \mathrm{ml}$ に ICGを $0.25 \mathrm{mg}$ 溶解した混合液を注入した。 腹腔鏡下では経皮的に穿刺を行つた。再発肝切除症例および鏡 視下の症例ではインジゴカルミンだけでは境界が不明瞭であつ たが、ICG 蛍光カメラを用いることにより全例で明瞭に門脈区 域を同定古ることが可能であった。また、術中の離断も蛍光カ イド下に行うことが可能であった。結語: ICG 蛍光法を用いる ことにより、従来の染色法では困難な再発症例あるいは鏡視下 でも安全で正確な系統的切除が可能となると考えられた。

PD08-1 当科15年間のキッズセミナーの試みと今後の展 望長崎大学大学院 移植. 消化器外科 ${ }^{1}$, 久留米大学病院 外科

伊藤信一郎 ${ }^{1)}$, 井上悠介 ${ }^{1)}$, 虎島泰洋 ${ }^{1)}$, 岡田怜美 ${ }^{1)}$, 米田晃 ${ }^{1}$,

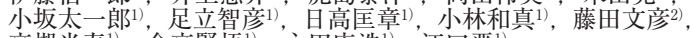
高梘光寿 ${ }^{1)}$, 金高賢悟1), 永田康浩 ${ }^{11}$, '江口晋1)

【はじめに】2005年に当時の兼松隆之教授の発案により長崎で開始 した外科手術体験キッズセミナーのきつかけの一つは外科医に 興味を持つ学生は、入学前から外科医志望があった」「外科医に興 味がない学生は、入学前から学がテイブなイメージを持つていた とのテキサスヒューストン大学の学生アンケート調査から、外科 医不足を解消するためには医学部に入る前から外科医を身近に感 じてもらう必要があると思いであった。これまでキッズセミナー は14回開催し、400人以上の生徒が参加している。【キッズセミナ 一】ミナーの対象は小学生から高校生で、長崎市内10回、県内 僻地 5 回の開催を行った。6グループに分かれ、(1) 救急救命、 (2) 最新医療機器、( 3 ) 自動縫合器、(4) 手術縫合、( 5 ) 内 視鏡トレーニング、（6）体のしくみ講座を体験してもらう。リア リティが重要とし、ガウン、マスクを着用し、自動縫合器、超音

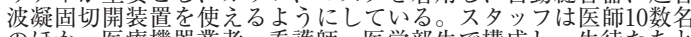
のほか、医療機器業者、看護師、医学部生で構成し、生徒たちと のコミュニケーションも非常に大切であり、外科医に対六る「恐 い」などのイメージを払拭するよう心がけている。【今後の展望】 実際にセミナー受講者が医学部入学し、外科医となった生徒も出 てきている。今後できるだけ多くの参加者が外科医を目指すには どのようなセミナーが望ましいのか、当科に拈けるセミナーの経 験、現状と問題点を報告する。
PD08-2 外科手術体験セミナー（キッズセミナー）の成 果の今後の展望市立大学 消化器 - 腫瘍外科学 ${ }^{1)}$, 横浜市立大学附属病院

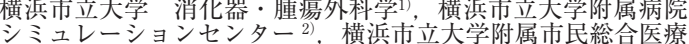
センター消化器病センター3)

秋山浩利1,2) 小坂隆司 ${ }^{1,2)}$ 黑澤由美子 2) 森田美和子 2) 佐藤渉 1 ) 佐藤圭 ${ }^{3}$, 宮本洋 ${ }^{3)}$, 土屋伸広 ${ }^{3)}$, 石部敦士 ${ }^{1}$, 渡邊純 ${ }^{3}$, 國崎主税 3 , , 遠藤格1)

目的：当センターで行っている外科手術手技体験セミナー参加者のア ンケート調查々進路調查上りセミナーの成果と今後の䘮望について考 察した。対象と方法：キッズセミナーは、2008年より年1回 7 月に開 催している。参加者は市内の小中高生で病院 HPと院内ポス夕ーより 募集している(定員 42 名)。セミナーの内容は 6 人グループで 7 つの ステーション (ER、縫合、内視鏡、腹腔鏡、手術室、災害救助など) を20分ずつ体験する。本セミナー参加者の当日のアンケート（応募理 由、満足度）とその後の進路をアンケートにより調査した。結果： 2008年より2018年まで10回、408名が参加した。応募理由は「医師ま たは医療に興味がある」が最も多く $62 \%$ であった。参加者および父兄 の満足度はいずれも $90 \%$ 以上であった。2019年4月に高校を卒業した と考えられる参加者は186名のうち、解答のあったのは95名で、医学 部入学者は 4 名 $(4.8 \%)$ であった（1 名は本学に入学 $)$ 。考察：セミ

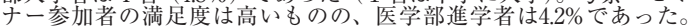
2019年の18歳人口約 117 万人本邦医学部82校の定員合計数は9419人 から算出される医学部進学率 $0.8 \%$ と比較すると高いものの、本セミナ 一が医学部進学にどの様な効果があったかは不明である。しかしなが ら本セミナーの副次的な效果として、一般市民との交流や病院のイメ ージアップ、院内職員 (医師、看護師、事務など) の交流などがあり、 今後も継続して行っていく予定である。

PD08-3 地方都市におけるキッズセミナーの開催意義 弘前大学消化器外科1), つがる西北五広域連合つがる総合病院 消化器外科2

坂本義之 ${ }^{1)}$, 和嶋直紀 ${ }^{2)}$, 石戸圭之輔 ${ }^{1)}$, 諸橋一1), 木村憲央 ${ }^{1)}$, 三浦卓也 ${ }^{1}$, , 佐藤健太郎 ${ }^{1)}$, 袴田健—1)

二次医療圈を 6 つ抱える本県では医師・看護師不足が顕著であ り、県内で働く医療従事者確保が急務である。そこで県内唯一 の大学病院である当院では、消化器外科を中心として、2009年 より小中学生・高校生を対象とした外科手術体験セミナー(キ ッズセミナー) を年 1 〜 2 回開催してきた。2018年まで県内 6 市で11回開催し、計 635 人の受講者があった。参加高校数は23 校におよび、参加者の 8 割が医師希望で、2 割が看護師や薬剂 師希望であった。セミナーの内容は多少の変更はあるが、主に 手術室体験、超音波メスによる切開・切離体験、縫合手技体験、 内視鏡下手術での鉗子操作体験、医療用顕微鏡を用いた形成外 科手術体験、自動縫合器体験の 6 つである。セミナー終了後に 全員にアンケートを行っているが、「外科医、外科手術って怖い」 というイメージが「外科医って優しい、格好いい、手術で人を 助けたい|という思いに変わったという意見を多数いただいた。 当大学の医学部医学科の県内出身入学者数はここ数年は年に43 〜 51 人であるが、そのうちこのキッズセミナー受講者の割合は、 2016年が33\%、2017年が32\%と 3 割を超えるようになってきた。 外科医不足が社会問題となっている中、このような外科に興味 を持った学生が多く入学してきていることは、地方都市での外 科医増加に寄与专るものと考えている。

PD08-4 外科手術体験キッズセミナーと体験者の進路に 市立函館病院 消化器外科 笠島浩行

【はじめに】当院では2008年から中学生を対象に「外科手術体 験キッズセミナー」をこれまでに11回開催している。開催状況 と体験者の進路について述心゙る。基本的に 24 人の中学生を 4 人 グループに分け，6つの体験（系結び・縫合，内視鏡手術トレ ーニング, 超音波診断, 救急蘇生, 超音波メス・自動吻合器, バチス夕手術・血管吻合)をしてもらい, 終了後にアンケート 記入.【結果】応募総数676名で参加決定は262名(倍率3.8倍) 当日実際参加は253名 (男95：女158，2年生68\%) 参加理由 は「医師の仕事に興味」39.3\%,「セミナー内容に興味」 $34.0 \%$. 感想は「楽しかった」100\%，「医師の手術や仕事に興味を持っ た」 $100 \%$ 。面白い」が多かったのは内視鏡手術 $98.8 \%$ 。将来 なりたい職業は医師 $43.9 \%$ ，看護師 $13.4 \%$ ，医療関係者 $17.0 \%$. 【進路】現時点で高校を卒業した体験者174名に進路調査を行い, 医学部通学中10名, 看護師 6 名, 薬剤師 2 名, 臨床工学士 2 名, 理学療法士 2 名.ほかに医師を目指して浪人中 2 名の回答を得 た。【まとめ】運営には外科系医師, 初期研修医のほか, 看護師, 検查技師, 事務職員も沢山参加しており, 中学生が外科医の手 技を体験するたけでなく, 職員と接することで病院の需囲気や チーム医療の大切さを感じ取っていただく貴重な場にもなって いる。.今後も地域の中学生が医療職を目指すきっかけになって くれるように, 継続して開催していきたいと考えている. 
PD08-5

当院での中学生対象外科医体験セミナーの経験

上都賀総合病院外科

知久毅, 佐野渉, 橋場隆裕, 篠田公生, 山本祐也, 十川康弘

【はじめに】当院では、2010年より毎年、中学生を対象とした 外科医体験セミナーを開催している。これまでの実績を振り返 り、明らかになってきたこと、今後の課題について検討した。当 院での実施内容】20名前後の中学生を公募にて選考し、開催白 としては、夏休みの土曜日の午後とした。選考の参考にするた め、応募時に抱負、希望事項を提出してもらった。当日の、内 容としては、1) 手洗いとガウシテクニック体験、2)腹腔鏡 トレーナーを用いた腹腔鏡手術体験、3) ブ夕の骨を用いた骨 折モデルの整復固定、4) 結紮縫合体験、人形用いた気管挿管 体験等を設定した。明らかになった課題】1、開催時期の設 定は、学校行事との兼和合いを考え夏休みとしたが、逆に夏休 みの予定とかさなることがあること。2，当初は、近隣施設で の同様のイベントが珍しかったことから、応募が多かったが、 その後減少倾向にあること。3，針等の鋭利な器具を使用する ための安全対策とともに、マスク、帽子、ガウン等を着用守る ことが意外と負担になること等にも注意が必要。4, 対象が中 学生でいいのか：参加してくれた中学生がその後ずっと医療に 興味を持ち続けてくれるかは不明であること。【今後の展望】 初回から10年となる今春、第一回の参加者の中で、1名が看護 師の職に就いた。今後も、参加者が進路選択にあたり、このセ ミナー参加がどの程度参考になったか等につき評価を行い今後 の改善につなげたい。

PD08-6 当院における中学生を対象としたキッズセミナ 一活動の現状 手稲渓仁会病院 外科

西智史, 中村文隆, 佐々木啓太, 市丸千聖, 萩原絢哉, 七里圭子, 藤井正和, 梅本二史, 古川聖太郎, 岡田尚也, 武内慎太郎,

今村清隆, 山吹匠, 高田実, 加藤健太郎

当院は北海道札幌市手稲区に位置する670床の地域医療支援病 院であり、2013年より区内の中学生を対象としたキッズセミナ ー「ブラック・ジャックセミナー」を開催している。週末の 日中を利用した 4 時間のセミナーで、当院の特色として、実際 にガウンを着用して手術室での体験を行つている。結紮・トレ ーニングボックス、腹部超音波検查の体験に加え、手術室では、 超音波切開装置の体験、手術台の上での鶏肉を用いた縫合練習 に加え、手術シミュレーターを用いた胆囊摘出術の体験や、手 術支援ロボット体験を行い、最新で実臨床に近い経験が得られ るような内容としている。延べ165人が参加したが、うち外科 医志望者は、45\% (75/165) で、看護師や医療者以外の志望者 も見られた。セミナー後のアンケートは、自由記載に手術室で の手技体験についての感想が多く挙げられ (18/86)、印象深い 経験となっていると思われた。さらに、今後知りたいことにつ いてもアンケートを行った。実際の手術も体験してみたいとい う意見のほか、他職種や業務やドク夕ーヘリについてなど、外 科に限らない実際の業務に対する興味が強いと考えられた。外 科志望者のアンケート結果に注目すると、最新の機器や実際の 手術手技に触れることが好印象であり、当院のプログラムは、 臨床に即した体験を行うことで参加者に強い印象を与えられた と思われる。

PD08-7当院における「高校生外科体験セミナー」につ 岡崎市民病院 外科

白浜功徳, 鈴木章弘, 森俊明, 石山聡治, 薮崎紀充, 本田倫代, 松本理佐, 伴友弥

当院では、主に岡崎市内の高校生（第 1 回のみ中学生）を対象 に外科体験セミナーを7月末に開催している。2009年から全10 回開催し、のべ322名（男性110名、女性212名）が参加した。 第 7 回からは参加者の進路志望も聴取しており、内訳は医師が 98名、他医療從事者が42名であった。対象は「医師または医療 従事者の仕事に興味のある高校生」とし、市内の全高校から広 く募集しているが、地元進学校からの参加が181名と最多であ つた。セミナーの内容は年により変えることもあるが、主に「診 察室での問診・身体診察・鑑別診断体験」、「手術機器の操作体 験」、「手術室での模擬執刀体験」を行っている。体験後のアシ ケートでは、ほぼ全員が「すごく満足した」ないし「満足した と回答し、内容別では「手術機器の操作体験」の満足度が最も 高かった。個人情報などの面から追跡調查が難しく、受講者の その後の進路を知ることができなかったが、本セミナーへの参 加を契機に医師を目指すようになり、最終的には当院の初期研 修医となったという受講者も毎年 1 名のペースでおり、根強い 継続が肝要と考える。本セミナーの現状と課題について、2019 年 7 月に開催予定である第11回の結果もふまえてさらに検討す る。
PD08-8

医師志望者に焦点を合わせた循環型高校生手術

香川大学 医学部附属病院 手術部 ${ }^{1}$, 香川大学 医学部 消化 器外科 2

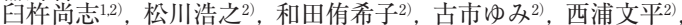
近藤彰宏2), 野毛誠示 ${ }^{2}$, 上村淳 2 , 須藤広誠2), 浅野栄介 ${ }^{2}$,

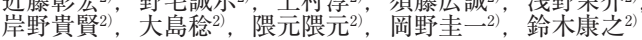

本体験型セミナーに各々の立場から寄せられる異なった要望に関 する本学での取り組みを報告する。指導者側からは負担軽減と負 担に見合った成果が求められ一方、受講者の満足度には自身が 手を動かす体験時間の長さと体験内容の多彩さが影響する。必要 な指導者数確保と負担軽減および実技の多彩さを確保するために 外科以外の外科系診療科 (脳神経外科・泌尿器科・形成外科・麻 酔科等）の医師や手術部看護師の協力を得、皮膚縫合・拡大鏡下 血管吻合・顕微鏡下綘合手技・鏡視下手術手技(2種)、ロボット 手術シミュレーショシ・血管結禁切離・術前手洗い・気管内挿管 などを幅広く行って来た。十分な体験時間確保の為には少人数の 定数制とし、各高校に過去の入学者数比率で受講人数を割り当て ているが、これは成果の一指標とも言える受講者の入学率向上に 寄与している。さらに、外科の臨床実習を終えた学生(主に6年生) が手術実習の体験談を話し、高校生から質問を受ける時間を設け ている。受講生に近い年齢で似た立場から類似の視点で見た感想 が聞け、質問もできることで受講生には非常に好評である。こ で体験談を話吉医学生の多くは、自らも高校時代にこの「体験七 ミナー」の受講経験を持っており、高校生達に「次は自分が後輩 たちに経験を語る」子の夢を持たせているが、方、医学生から も「良い経験」との声があり、その学生が後に外科医にという卧学生から イクルが生まれている。

\section{PD08-9} Gender Diversity 教育を兼ねた外科手術体験キ

不ゼナー

消化器外科

河野恵美子, 谷口高平, 田中慶太朗, 奥田準二, 内山和久

厚生労働省統計資料（医師・歯科医師・薬剂師調查）によると 2016年の病院に従事する外科医師数は11293名，平均年歯令は 49.1歳である。約10年前と比較すると外科医師数は 3 分の 2 に 減少, 平均年齢は 5 歳上昇しており, 急激な外科医数減少かつ 高齢化を迎えている。一方，女性の割合は急増しており，Gen der Diversityを実現し男女問わず活躍できる外科社会に変容 していく必要がある。今回我々は外科の将来を見据え「Gender Diversity 教育を兼ねた外科手術体験キッズセミナー」を企画 した。対象は中高生の男女とし，定員は30名とした。講師は女 性の割合が少ない消化器外科 $(6.4 \%)$ ，心臓血管外科 $(6.2 \%)$ 脳神経外科 $(6.0 \%)$ の 3 領域の女性医師とした。セミナーは2 部構成とし, 1 部は「外科医の仕事と魅力, 女性のキャリア に関する講演, 2 部は 3 領域のハンズオン (内視鏡手術トレー ナーによる錐子操作，消化管器械吻合，人工血管吻合，サージ カルドリルを用いた模擬頭蓋骨削除手技,脳動脈瘤コイリング） とした。より外科の魅力を伝える工夫として実際の手術手技ビ デオを供覧した。セミナー前後にアンケートを実施し，外科へ の興味,アンコンシャスバイアスに関する意識変化を調査した 本セミナーのようにGender Diversity教育を兼ねたキッズセミ ナーは過去に実施例がなく, アンケート結果を含め内容を報告 する.

PD09-1 優れた臨床外科医を育てるために：指導者の姿 慶應義塾大学医学部外科 北川雄光

この度会長の花崎和弘先生より、恩師北島政樹先生とともに パネル演者に選出していただきました矢先に、2019年5月21日 北島先生の急逝という思いもかけない事態に遭遇しました。今 も現実を受け止め難い思いでおります。今回、花崎先生より追 悼の意味も込めて発表の機会をいただきましたので謹んで恩師 から学んだ臨床外科医育成の理念についてご紹介いたします。 1991年 5 月、本学外科学の教授となられた北島先生は、内視鏡 外科の導入と普及、生体肝移植の開始、アジア初のロボット支 援手術導入、医工連携の推進など、圧倒的な先見性とリーダー シップ、決断力で次々と新たなプロジェクトを推進されました。 指導者として大きな方向性を示し、最も適切な人材を登用して 実務を遂行させ、それぞれの意欲と能力を最大限に発揮させる 「力」はまさに圧倒的でした。そして、いかなる先端的医療を 実践する際にも、患者さんの利益、安全を最優先する強い姿勢 を自ら示されました。自ら、患者さんに良いと考えた方針につ いてはいかなる障壁も乗り越え、実践する強い意志を目の当た りにして、我々教室員も勇気を持って追いて行くことができま した。常に結果は結果として受け止め、努力を意ったり不誠実 な対応をした場合にのみ厳しく指導されました。その公正かつ 誠実な姿勢が教室から多くの優秀な指導者を輩出する原動力に なったように思います。 
PD09-2-1＼cjkstart恩師から学んだこと 名古屋大学腫痬外科 梛野正人

私は卒業後、安城と言う中小都市にある中規模病院で卒後研修 を始めました。その病院に生涯の恩師となる二村先生が週に一 回、ネーベンに来られていました。先生は、当時、名古屋大学 第一外科の講師であり、肝胆膵疾患の診断と治療に情熱を注し でみえました。特に、経皮経肝胆道鏡検査を駆使して、胆道癌 の術前診断や肝内結石の治療を積極的に行い、胆道外科の面白 さを我々に教えていただきました。影像下直達法による経皮経 肝胆道ドレナージ (PTBD) の手技は二村先生に教えていたた いたものです。以来、40年以上にわたり、ずっとずっと先生の 背中を見ながら今日まで走って来たことになります。先生に教 えていたたいたことは沢山ありますが、教えの根幹は“諦める な!”と言うことに尽きると思います。諦めるのは簡単で、諦 めてしまえば楽になりますが、いうまでも心の片隅で後悔の尾 を引きずることになるかもしれません。“迷ったら、困難な方 を選びなさい”とも教えられました。その教えを守っできたの かと問われると“? ? ”と言わざるえません。しかし、選択を 迫られる度に必ずその言葉を思い出し、苦しんだことは間違い ありません。二村先生はゼロから胆道外科を作った偉大なパイ オニアであり、元代目の私とは雲泥の差があります。その関係 が“理想の師弟”であるのかどうかは判りませんが、先生から 教わったことをお話ししたいと思います。

\section{PD09-2-2 理想の師弟関係 - 弟子としての経験から 名古屋大学 腫瘍外科 名村雄次}

師弟関係とは経験によって培った知識・技能・精神などを伝授 する師匠と弟子との関係で、学問、芸能、武道、宗教などの領 域に見られる。私は人生で 3 人の師から大きな影響を受けた ので紹介したい

私は学生時代名大柔道部の岡野好太郎師範に学生柔道の真髄 (究極の一点に到達するための忍苦精進の精神) を学び、これ が人生の枉となった。医師になってからは癌研病院の梶谷鐶 先生から癌の根治手術と癌と闘う外科医の精神を学び、これが 癌外科医としての人生の柱となった。名古屋大学第一外科教 室では塩野谷恵彦教授から自然科学としての外科学 (英文論文 を書くこと）と専門分野の名古屋学派の樹立という二つの宿題 を頂く二方で、身を呈して沶し下さった指導者の倫理観はそ の後の私の人生観の柱となった。臨床外科分野では師は弟子 が外科学の修練に没頭できる環境を整備し(教育)、専門領域 での研究の陣頭指揮に立ち (研究)、患者中心の手術治療学の 基本姿勢 (臨床) を身をもって示さなければならない。弟子 は師厈が示された姿を必死になって学び、その知識、技能、精 神が二定の域に達する努力をする過程で師弟関係が酸成され る指道者となった者はその組織で盖成された精神を受け継 ぐ後進が玄成された時占で自らの進退去就を判断卞る必要があ る。機を得て精神が受け継がれた時に伝統が生まれて師弟関 係が成立するが、真の師弟関係はその後の歴史が証明してくれ る。

PD09-3-1 外科医は大人の知識と子供の感性の両方を持つ ベきである 長崎大学 移植・消化器外科 江口晋

表題は私の恩師である兼松隆之名誉教授の金言集「一見憧情」 のなかの、私が大好きな一節である。今振り返ると、兼松教授 からは、この二点を両立するような外科医になるようにと教え て頂いたと感じている。優れた臨床外科医となるための理想の 師弟関係については、浅学菲才の私にはまだ答えがない。そこ で今までの兼松先生に歩ませて頂いた道程を振り返ることで、 自分なりに考えていきたい。私はH4年に長崎大学を卒業した が、兼松教授はH3年に九州大学より赴任してこられた。エネ ルギッシュな若さが際立って目に映り、アカデミックな外科医 が外科学の発展のためには重要であるとの考えに共感し、この 先生に就いていきたいと考えた。節目で声をかけて頂き、私の すべき仕事の意味を教えて頂いた。例えば離島赴任の際も、そ の意義と故篠崎卓夫先生から手術手技、考え方をしっかり学ぶ 事が貴重と。帰学後は矢永勝彦教授より肝移植手術を習うよう に言い渡され、綮しいご指導に付いていつた。オランダから戻 つてからは、さらに厳しく御指導頂いたが、どんな時も兼松教 授は正直で真正面から物事に取り組まれたと思う。私が同様に 後進を育成皂ることができるか、今後の成果が語ってくれるこ とであろう。優れた臨床医、特に外科医は手術のみならず患者 さんの周りに存在する why, what感じ、それを解決するための 手段を考える感性を持つ必要がある。後輩外科医にもその感性 を磨くように日々伝えている。
PD09-3-2＼cjkstart私の「師弟関係」 長崎市立病院機構

兼松隆之

この企画で“弟子”役を担う江口晋教授と“師”の立場の私が出 会ったのは、私が九州大学から長崎大学に赴任した1991年。彼 は医学部 6 年生だった。縁あって翌年から同じ教室で外科の研 鑽を積むことになった。

組織を安定的に運営していくには、医局員に対してできる限り 平等に機会を与え、結果を公平に評価することが求められる。 江口教授もその環境の中で育った。臨床研修、海外留学や離島 を含めた関連病院での勤務を経験し、教室の助手となり、再び 私と一緒に仕事をした。当時、彼はすでに優れた臨床外科医と なっていたことからしても、彼を育て上げたのは、私との師弟 関係ではなく、周囲の協力に加え、彼の素養、素直な性格、た ゆまぬ努力の賜である。そのような江口教授に限らず、医局員 の誰一人として、私は“弟子”と思ったことはない。同じ夢を見、 苦労を共にした“同志”と考えている。彼は教室で医局長、 助教授の要職を首尾よくこなし、組織運営能力も身につけた。 その江口教授は私の後継者として選出された。当然、私とは年 齢の開きがある。だが、組織にとってこの年齢差をいかに意義 あらしめるかは重要で、一代一代がバラバラでは何の歴史も生 まれてこない。歴史を継続していくためには良きものは継承し、 悪しきを捨て、独創を生むといった積み重ねが必要である。そ れを実践するのは容易ではないが、“同志”江口教授を後継者 に得たことを幸いに思っている。

PD10-1 若手外科医に魅力的な地方創生の教育システム 佐世保市総合医療センター1), 長崎大学病院腫瘍外科2), 諫早 総合病院 ${ }^{3)}$, 嬉野医療センター - ${ }^{2}$, 長崎医療センター5), 済生 会長崎病院 ${ }^{6)}$, 株式会社クリプトン

濱田聖暁 ${ }^{1)}$, 荒木政人 ${ }^{1)}$, 野中隆 ${ }^{2}$, 福岡秀敏 ${ }^{3)}$, 黨和夫 ${ }^{4}$, 竹下浩明5), 田中賢治 ${ }^{6)}$, 松本桂太郎 ${ }^{2}$, 濱田正久 ${ }^{7)}$, 永安武 22

地方都市は多数の症例が集まる都市部のハイボリュームセンター と比較し、マンパワー不足や地理的問題により施設毎の手術手技 の定型化に関しては不利な点も多く、腹垫鏡下手術ではそのquality control safety control が課題となっている。また都市部では 最先端の医療を経験できるというメリットで若手外科医が都市部 に流れることが多いなか、われわれは地方のデメリットを克服す るために大学とその関連病院が連携してNagasaki Oncology Groupとして手術手技の均てん化、デー夕集積を行っている。手 術手技の均てん化として1.wet labo(ブタの臓器を使用した手術手 技実習)、2.animal laboのトレーニング、3.カダバートレーニング、 4.大学拉よび関連施設の医師によるビデオ研究会、5.関連病院へ の技術認定医の出張手術による手術指導などを行っている。それ らの取り組みにより長崎県下の病院で手技の均一な腹腔鏡下手術 が可能となり、複数の内視鏡外科学会技術認定医が誕生してきた。 デー夕集積では長崎県下の関連病院群における大腸癌データベー スとして年々症例数は増加しており2018年度は大腸癌663例を集 積して、施設間格差を明らかにしたり学会発表を行ったりしてい る。さらに大学はタビンチ手術などの高度先進医療を習得できる 施設としての機能を担い、離島医療圈をもつ地方都市として遠隔 医療システムの開発も行うことで若手外科医の獲得・教育につな げようと画策している。

PD10-2 研修の取り組み 鳥取大学 消化器外科

多田陽一郎，原和志，菅澤健，植嶋千尋，谷尾彬充，宮谷幸造， 木原恭一, 松永知之, 山本学, 福本陽二, 徳安成郎, 高野周一, 坂本照尚, 本城総一郎, 藤原義之

近年，ロボット支援下手術をはじめとする低侵襲手術は劇的に進 歩を遂げている. 当院では DaVinciが導入されるに当たり，2011 年に低侵襲外科セ多一(外科系診療科・麻酔科・手術部看護師 . 臨床工学技士）を設立し，院内規定によってカンファレンスで対 象手術全ての報告を義務化し, 最新治療や術中アクシデントの情 報共有を可能とした。 量の上限を設け, 超過した場合は当該診療科以外の責任医師が手 術継続の可否を判断することとした、さらに新たな取り組みと 乙一姐盤内臓器を扱方消化器外科. 婦人科. 泌尿器科の若手医師 を対象に各科を 3 ヶ月間ずつ研修し, 骨盤解剖・杽術手技などを 習得与るプログラムが2016年に開始された。実際のローテーショ 吾は治療方針決定から術後治療まで関わり, 手術では助手だけ でなく執刀医としても参加する，指導内容を明確化するため，そ れぞれの科に到達目標が揭げられている。 ローテート要員が少

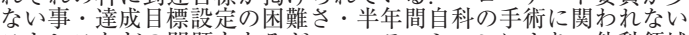
ストレスなどの問題もあるが, ローテーションにより, 他科領域 の治療方針・骨盤解剖を学べるだけでなく、多診療科連携がス厶 ーズとなり，結果として高難度手術の医療安全向上に貢献すると 考える。開始してまだ間もないが、少しすす修正を加えながら地

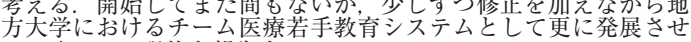
ていく。この現状を報告する。 
PD10-3

地域中核病院外科における若手外科医教育

兵庫県立柏原病院 外科1) 袖戸大学 食道胃腸外科2)

大野伯和 ${ }^{1)}$, 岡副佑城 ${ }^{1)}$, 杂倠賀裕士 ${ }^{1)}$, 美田良保 ${ }^{1)}$, 岸淳彦 11 ,

藤田恒憲 ${ }^{1}$, , 鈴木知志 ${ }^{2}$

兵庫県立柏原病院は、兵庫県丹波地方の中核病院であるが、常 勤医師数の著しい減少で一時病院機能が低下。病院閉鎖の危機 に見舞われたが、地元住民、自治体や大学の支援、更には教育 体制の充実により若手医師を集める病院を挙げての取り組みに よって病院機能を徐々に回復しつつある。当院は許可病床303 床、稼働病床184床であり、外科病床数は25床、平成30年度の 全麻手術件数は346例の非都市部病院である。若手医師が経験 する手術症例も限られたものとなるが、指導医の密着した指導 のもと、症例検討、主治医執刀から標本整理、手術所見作成に 至るまで 1 例ずつ症例を大切に積み重ねることで、都市部病院 に負けない外科医の基本を習得することができると考えてい る。具体的には、専攻医 1 年目では約 3 か月の助手経験を経て、 夏頃より主治医開腹手術は基本的に先発完投型の術者、胆石や ヘルニアに扔いては腹腔鏡も術者。2 年目からは習熟度合に応 じて、悪性疾患の腹腔鏡手術も徐々に助手から術者への移行を 可能な範囲で進めている。また消化器内科と合同の内視鏡力シ ファや外国語文献抄読会、総合外科研修の一環として上部下部 内視鏡検查の研修も取り入れている。こうした種々の取り組み により、徐々に症例数も回復。当院初期研修医から外科専攻医 に進む医師も出てきている現状である。今回病院全体で取り組 んだ教育環境の整備など当院外科での若手外科医教育の取り組 みを発表する。

PD10-4 地方病院での外科研修（後期研修）の実情 地 方病院だからできること

北信総合病院

町田ミズホ, 内藤一樹, 篠原剛, 山田博之, 藤森芳郎

当院は地方小都市の病院ではあるが、積極的に研修医（初期及 び後期研修医）を受け入れている。外科手術件数は年420件程 度で外科医歴20年以上の常勤医 4 名の体制であり、それぞれ専 門分野での指導医、専門医資格を有し、内視鏡外科学会技術認 定医も 2 名おり、規模は小さい病院ではあるが教育体制は整つ ている。最近の 2 年間で大学医局からの派遣で後期研修医 3 名 （後期研修 1 年目 1 名、 2 年目 2 名）を受けいれた。当院の研 修では手術の執刀を早期から経験することが非常に大事たと考 えており、虫垂炎、絾径へルニアといった外科研修の初期に経 験する疾患に加え、胃癌や大腸癌、内視鏡手術も執刀医として の機会を与えている。研修の 1 年間でそれぞれの研修医が術者 として115、129、130例、助手として139、103、103例と多くの 症例を経験している。研修開始当初は、当院での後期研修に不 安があつたようであるが、数多くの執刀が経験し充実した 1 年 を過ごしていただき、後輩に対して当院での研修を好意的に伝 えていただいているようである。地方都市では若手外科医が極 端に不足しているが、教育体制は整っている病院も多い。地方 都市では患者さんが寛容なこと、若手から中堅の外科医が不足 してることから、手術の執刀機会は都市部より多いのではな いだろうか。都市部の基幹病院での経験は非常に有用であるが、 地方病院で早期に様々な手術の執刀経験を積むことも大事では ないだろうか。

PD10-5

非都市部一般市中病院での若手外科医研修の取

り組み

相澤病院 外科

西田保則，小田切範晃，守安諒，関宣哉，砂川大輝，三島修治， 村山大輔, 竹内大輔, 吉福清二郎, 宮本昌武, 三澤賢治, 高賢樹, 笹原孝太郎, 田内克典

若手外科医にとっての修練の目的は、一般外科領域からサブスペシャ リテイー領域についての基本知識、手術手技の習得であり、都市部 · 非都市部でも変わらない。

当科では、2009年より継続的に後期研修医を採用し、3 年間のプログ ラムで充成している。後期研修修了後のサブスペシャリティー 領域での専門医を目指す若手も採用し研修を行い (専門医コース)、 希望者には短期国内留学も実施している。

2009 年から2019年までに、15名の外科医が後期研修を修了し、3名は 現在研修中である。研修 3 年間での参加手術数（平均）は709例、う ち執刀数 (平均) は4 19 例 $(59.1 \%)$ であった。執刀症例の中で、腹腔 鏡・胸腔鏡手術は89例 $(21.2 \%) 、$ 緊急手術は169例（40.3\%）だった。 専門医コースは 4 名で、消化器外科学会消化器外科専門医の手術難度 区分で中難度以上の手術の執刀模平均66例/年であ。学会・研 区究会べの参加は、アクセスの問題もあり都市部よりは難しいが、学会 登表については年 $3-4$ 回程度皘極的に行うなどしている

発表については年 $3-4$ 回程度皘極的に行うなどしている。救急救命センターも併設している。実際に手術を執刀するこ とを中心とし、定型手術のみならず、救急疾患への対応を経験するこ とで、外科医に必要な技能・知識の習得を目指している。専門医取得 に要する手術要件に関しても、研修期間中に経験ができている。地方 一般病院においても、若手外科医に必要な修練を提供することが可能 である。当科での実績と、取り組みについて紹介寺る。
PD10-6

若手外科医のやる気と休息を満たすための当科

富士市立中央病院 外科

害村雄也, 梶本徹也, 山田雄太, 後藤圭佑, 吉岡聡, 高野裕樹, 道射隆行，良元和久，吉田清哉，鈴木俊雅，柏木秀幸

初期研修 2 年を終えて、希望科での後期研修を行う若手外科医 は手術の執刀意欲に燃えているが、その一方で、症例数を優先 することで残務時間や当直回数が増え身体に不利益の出るよう な勤務形態にならないように考慮しなければならない。当院は 人口約 25 万人の静岡県富士市に位置しており、地域唯一の基幹 病院として24時間365日救急患者を受け入れている。当科は大 学医局より派遣された医師で構成されており、外科学講座に入 局した後期研修医が 2 名ごとに 1 年単位で勤務し次の勤務先に 移動していく。年間約800件の手術症例があり、その半分以上 を後期研修医が執刀医となり施行している（緊急手術症例では 約 7 割)。手術以外にも、病棟や内視鏡業務とともに、救急患 者の相談、初期䛦療、診察も同時に行わなければならないま た、地域の勉強会や、学会の地方会の発表も定期的に担当し行 つている。勤務の負担を軽隇するための対策として、当直回数 は月 4-6回にとどめ平日に1日休日を設けるとともに、緊急 手術時の呼び出しを減らし、上級医が分担する上うにしいる。 1 年間という短い期間の中ではあるが、症例数の確保はもちろ ん、手術の振り返りや手術録記載など数とともに質の確保と、 責任のある仕事が増えていくなかで、意欲を保ちつつ勤務に疲 憋しないことに留意している。当科での若手外科医への教育と 勤務への取り組み、今後の課題について報告する。

PD10-7 神奈川における若手外科医教育のジレンマと当 院での取り組み

相模原協同病院 外科

若林正和, 奥野晃太, 木村友洋, 船津健太郎, 原英則, 日高英二, 保刈岳雄

神奈川県は都心に近く, 大学病院やその基幹施設も多く, 卒後 の初期臨床研修医の勤務先として大変人気がある. 平成3 0 年度 の初期臨床研修医の採用人数は東京に次ぐ全国 2 位であった しかし, 神奈川県は他の都道府県に比較し, 医師が少なく（人 口10万対医師数で全国39位) 外科医はさらに少なく（人口10 万対医師数で全国 46 位)，外科専門医も少ない.そして，その多 くは横浜や川崎に集中し’, 地域偏在が強い.よって初期臨床研 修医は多いものの, 指導卞る外科医が少ないジレンマがある。 外科医の少なさから，相対的な仕事量も多く、しばしば他科に 比べQOLが低く、教育指導に手が回らず,外科医に興味がある 初期臨床研修医の希望の芽を摘んでしまっている可能性もあ り, 外科医数の増加は, その他の都道府県以上に喫緊の課題で ある、さらに後期研修においては、新専門医制度が始まり、基幹 施設と連携施設での修練がプログラムされた、当院は連携施設 であったが, 基幹施設の条件を満たし今年度申請した。基幹施 設の多くは大学病院や公立病院であるが, 当院では初期臨床研 修から後期臨床研修まで一貫して行い, その後にはスタッフと しての道も開かれており,天学外科教室に属してない総合病院 の外科として, 大学病院之はまた違う外科医教育を実践できれ ばと考えており，その取り組みについて報告したい。

PD10-8 当院における若手外科医教育

大曲厚生医療セン多一外科

小野文徳，䈉木孝明，小村俊博，谷口肇，佐藤将大

【緒言】当院は非都市部の二次医療圈における中核病院であり， $20 \sim 30$ 代の若手外科医師が多く在籍している. 当科では, 初期 研修医(卒後 $1 \sim 4$ 年目) にも早くから外科的手技や手術の執

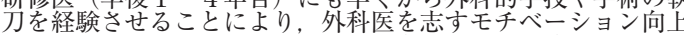
を目指してきた。また, 後期研修医（卒後10年前後）の場合は, 自分よりも下級医を助手としてメジャーな手術を行えることを 目標としてきた。【目的】2004年以降，当院で研修した若手医 師の手術執刀数を集計するとともに,アンケートを実施して当 院での研修がその後のキャリアに度ほした影響などを評価し た.【結果】新臨床研修制度開始以来, 66名の研修医が当院の 臨床研修を終了し，このうち外科を専攻した医師は24名であっ た。また。同時期の外科後期研修医は11名であった。初期研修 医は小手術〜上下部消化管手術程度まで執刀し，病状説明，検 查，IVRなども多く経験した。卒後 $3 \sim 4$ 年目まで研修を行っ た者の執刀数は約 $120 \sim 250$ 件であった。外科志望であった者か 他科に進路変更したケースは皆無であった一方, 他科から外科 志望に変更した者は数名存在した。後期研修医の場合， 3〜4 年程度研修することでメジャーな手術を下級医相手に執刀する 経験を多く積んだ。アンケートでは初期扔よび後期研修医とも に当科での研修を概ね高く評価したが, 不足していた点や問題 点も浮き彫りとなった。地域的な特色を含め,これからの若手 外科医教育について考察专る。 
国立がん研究センター中央病院 大腸外梨
井上学, 金光幸秀, 志田大, 塚本俊輔, 弘, 坂本良平, 高見澤康之

【背景】近年、外科医を取り巻く環境が変化している中、高齢 化や多様化社会に伴い, 総合的な診断能力を有する専門医の社 会的ニーズが高まってきている。目的】都市・地域两面の外 科医教育実態や施設の土夫を紹介し、社会から求められる専門 医像に関して自身の経験から考察する。【対象と方法】当方 は外科初期研修を沖䋥県立中部病院で開始し、離島研修として 県立宮古病院での勤務を経て、国立がん研究センターに修練医 を含め計 4 年間在籍した。結果】地域、離島医療で特筆す心 きは、頭から足の先まで幅広く一般外科領域をカバーし、全人 的医療が学べる事である。医療資源が限られる中での診療を強 いられ、医師としてあらゆる緊急疾患対応や幅広い知識が必要 で, generalistとしての基礎が鍛えられる。年間約1000例の一 般外科手術があり、後期研修までの 4 年間で約600例（術者約 350例）の手術を経験する。その後、都市部の専門病院で専門 医を目指し、年間約600例の大腸癌手術症例を短期間に集中し て研鑽を積んだ。あらゆる術式、症例を体感し治療の最前線に 立つことで専門医としての技量や視点を銓えられる。こうした 地域医療と専門研修との融合により、特定の蔵器や疾患を超え た多様な問題を抱える患者に対する“全身が診れる専門医”へ と繋がると思われる。【結論】都市、地域两面の若手外科医教 妄の融合により、総合的な診断能力をもつ外科医教育につなが る。

PD11-1 外科臨床におけるEBMの実践 東京女子医科大学 乳腺・内分泌外科、衛生学公衆衛生学 岡本高宏

診断から手術、そしてその後の経過に至るまで臨床には不確実 さが尽きない

【エビデンスとは何か患者と医師は不確実さのもとで決断し なければならない。その不確実さを数值化したのがエビデンス である。降水確率を知って苶を持ってゆくかどうかを決めるよ うに、不確実さの程度をどう受け止めるかが臨床決断にかかわ る重要な要素のひとつである

【エビデンスは正しいか】 大切な決断を誤らないためには正し い数值 (エビデンス) が不可欠である。適切なエビデンスが存 在しないことも稀ではない外科臨床で、EBMを実践するため に外科医が為す心゙きことが 3つある。第一はエビデンスを探し 見つけることである。限られた時間の中で探すリソースのひと つは診療ガイドラインである。また、診療ガイドラインは EBMを実践可能にする仕様であることが望ましい。第二は見 つけた数值が正しいかを吟味することである。吟味の要点は内 的妥当性と信頼性にある。このとき臨床疫学の知識があると役 に立つ。

【エビデンスは当てはまるか】外科医が為すべきことの第三は EBM 以外の知識と技能そして態度を磨くことである。患者集 団での平均値とも言えるエビデシスが目の前の一人の患者にそ のまま当てはまるとは限らない。基礎医学を含めた幅広い知識 と臨床経験を重㸚た技能、そして相手を想う忍がエビデンスを 活加。

\author{
PD11-2 胃癌外科手術に関する臨床試験の結果とその解 \\ 瀵岡がんセンター 胃外科 \\ 寺島雅典
}

日本臨床腫瘍研究グループ (JCOG) では1990年代から胃癌手 術に関する大規模な無作為化比較試験 (RCT) を実施してきた。 に関するRCTを実施した。その結果、術後合併症が増加する ような過大侵襲を伴う拡大手術においては、击しろ再発が増加 し治療成績の向上を得る事は出来なかった。これらの試駼結果 から、低侵襲手術や周術期化学療法に対する期待度が堌すき。 かっけとなった一一方、cStage I胃癌に対しては、開腹胃切除 に対する腹胿鏡下胃切除の非劣性を検証する9201試験を実施 し、腹腔鏡下胃切除の非劣性が証明された。また、腹胿鏡下胃 全摘・噴門側胃切除の安全性を検討する単アームの検証的第 III相試験（JCOG1401）も実施L、腹腔鏡下胃全摘・噴門側胃 切除の安全性が確認された。これら二つの試験結果から、 cStage I胃癌に対しては腹腔鏡下手術が標準治療となるものと 思われる。臨床試験は限られた施設において、限られた対象に 対して、細かく規定された治療を行うものである。従って、そ の結果を実地臨床に応用する際には、対象患者の適格条件、施 設・術者規準、試験治療の内容などに関して熟知しておく必要 がある。また、適格条件以外の患者に対しても結果の外挿が可 能かに関しても判断が必要となる。海外で行われた試験に関し てはその質に関しても留意しなければならない。

絹笠祐介, 松山貴俊, 菊池章史, 山内慎一, 馬場裕信, 高岡亜弓, 松宮由利子, 青柳康子, 山本雄大, 茂原富美, 笠井俊介, 田澤美也子, 山下大和, 塩原宽之, 徳永正則

近年、進行大腸がんに対する腹腔鏡下手術と開腹手術の根治性 に関するランダム化比較試験（JCOG0404）と臨床病期 IIIIII の 下部直腸癌に対する神経温存 D3郭清術の意義に関するランダ 厶化比較試験実(JCOG0212) の結果が報告された。0404試験 では、腹哚鏡手術群の開腹手術群に対する非劣性が検証されな かったものの、腹腔鏡手術は acceptable optional treatment $と$ 位置づけるものと解释された。サブグループ解析では、高難度 と考えられる群で開腹手術群が良い傾向にあり、合併症や予後 において、施設間格差が腹腔鏡手術群で生じ、何でも、どこで も腹脘鏡手術でという考えに対しては警鐘を鳴らすものとなっ た。0212試験では、ME群の 5 年無再発生存率の ME+LLND 群に対するハザード比は1.07となり、ME単独の ME+LLNDに 対する非劣性は示されなかった。副次的評価項目である全生存 率、無局所再発生存率では有意差がなく、側方郭清の生存改善 効果は限定的であることが示唆されたものの、局所再発の頻度 はME群に比べてME+LLND群で有意に低率であり、側方郭 清の持つ効果というものが如実になった。手術手技のラシダム 化比較試験は立案・実行することが難しいだけではなく、その 結果の解釈も曖昧になりがちだが、ランダム化比較試験だから こそ得られる重要な結果を、外科医は汲み取る必要がある。

\title{
PD11-4
}

う活用するのか

大網白里市立国保大網病院 外科 ${ }^{1)}$, 千葉大学 臟器制御外科 2 吉留博之 $之^{1)}$, 安赫聡 1 , , 大塚将之 $之^{21}$

EBM (Evidence-Based Medicine)「科学的根拠に基づく医療」 を行うにあたり、科学的根拠としてのエビデンスをどう理解し 運用するかは一般臨床外科医にとって重要な問題である。医療 の本質は、医療者の専門性と患者さんの希望とを勘案して判断 を行わなくてはならないが、年の専門性を担保するためのエビ デンスとして一般にはRCTや meta-analysisを参照することが 必要であるが、その習得は容易でないことも多い。現在は論文 のみならずinternetよりガイドラインを参照するなど、その利 便性は向上してきている。得られた情報を解析して、臨床に feedbackすることを総合的に判断して実地臨床に役立てるこ とにしている。 EBMを含めた総論を提示し、その活用法を 検討したい。

PD11-5 臨床外科現場におけるEBMの活用について 横浜市立大学 消化器·腫癔外科学 遠藤格, 本間祐樹, 藪下泰宏, 三宅謙太郎, 中山岳龍, 熊本宜史, 松山隆生

肝胆膵外科診療においては、単一施設における症例数の少なさ ゆえエビデンスの創成が少なかったが、最近ではエビデンスの 発信が増えつつある。EBMを活用するにあたつて、当然なが ら研究の質を重視しなければならない。ランダム化比較試験の メ夕解析は有用だが個々の研究の質を吟味すべきである。言い 換えると各論文を選択する方法論吕誤っていると結論をミスリ ードする可能性があることに注意すべきである。次にランダム 化比較試験になるが、あくまでも患者の安全が確保できる事が 前提で症例数も数十から数百でありリアリテイに欠けた試験も あり、再現性や均一性も完璧ではないことに注意すべきである。 Historical control を伴う前向き研究は行われるが、前期・後期 の間にいくつかの交絡因子が隠れていることに注意すべきであ る。最も多く行われるのは後ろ向きのケースコントロール研究 だと思われるが、多くの交絡因子が存在することは自明である。 より批判的吟味が加わったPropensity Score Matchなどの手 法を用いた研究を参考にすべきである。最近ではビッグデータ の時代となり、前向き登録あるいは後ろ向きであっても大きな データベースを用いた研究が増加している。ビッグデータのサ ブグループ解析が案外世の中の実相を示していることも多いの で活用すべきである。今回は教室の肝胆膵外科領域における EBMの取入れ方について紹介したい。 
PD12-1

極小切開法による小肾鼠径へルニア根治術

群馬大学 小児外科 ${ }^{1)}$, 群馬大学 総合外科 ${ }^{2}$, 獨協医科大学 埼玉医療センター 小览外科

鈴木信 ${ }^{1}$, 小山亮太 ${ }^{1)}$, 内田康幸 ${ }^{1)}$, 大串健二郎 ${ }^{1)}$, 大竹紗弥香 ${ }^{1,3)}$, 山本英輝 ${ }^{1}$, 池田均 ${ }^{3}$, 調憲 ${ }^{2}$

【はじめに】小児鼠径ヘルニアに対する手術は20世紀初めより 鼠径アプローチ法によるヘルニア襄の単純高位結皆術（Potts 法) が行われ、現在も国際的に標準術式となっている。一方 2003年に嵩原らによってLPEC法が紹介され、腹胩鏡下ヘルニ ア修復術の保険収載とも重なって、本邦では標準術式として採 用守る施設が増えてきてはいるがNCD登録上は従来法の半数 に満たない施行数である。当科では従来Potts法を行ってきた が、2013年 4 月より2006年に池田らが考案した極小切開法によ る高位結紮術 (Selective Sac Extraction Method : SSEM) を 採用し標準術式としている。当科における結果を報告する。対 象】2013年 4 月-2018年12月までの157患側 (男67例、女81例、 年龄 1 ケ月-15歳) を対象とした。嵌頓例、停留精巣、巨大水 瘤合併、卵巣滑脱へルニアおよび低出生体重児症例は除外した。 【結果】完遂率 $94.2 \%$ 、手術時間13-86分（両側例・他疾患合併 例を除く、中央値36分)、術後創長は4.5-22 mm (中央値6.5mm)、 術後観察期間での再発や合併症なし。【考察】小児鼠形へルニ アに対寻るSSEMは術創の整容性を保ちつつ、創外での操作は 従来のPotts法と同様であり、特殊な器具を必要とせず施行で きる利点を有する術式である。ただし、ヘルニア襄を選択的に 創外へ引き出すには若干の修練が必要で、従来法に比べ手術時 間の延長を認めた。

PD12-2 小児LPECの適応と限界

北野病院 小児外科1) 大阪市立大学 小児外科 2 ,

諸富嘉樹 1 ), 佐藤正人 ${ }^{1)}$ ，遠藤耕介 ${ }^{1)}$, 東尾篤史 ${ }^{1)}$, 堀池正樹 2 , 北田智弘

【はじめに】 LPECはPotts法と同等の高位結紮ができる術式と して国内で普及しているが、ヘルニア囊を離断しない占が異な る。そのため術後精系水腫発生の危惧や長期成績に疑問が残る。 われわれは2005年にLPECを開始、精系水腫にも寒施した。14 年の成績から LPECの適応と限界を考察した。【対象と方法】 LPECを実施した 1272例を対象に再発・対側発生を検討した。 修正週数 50 週以降の鼠径ヘルニアと 1 歳以降の水腫を適応とす る。有症状側对側の内鼠径輪開存は閉鎖しているが、2009年は 対側開存径が5mm以下でveil を伴う場合は保護者同意のもと 放置した。【結果】再発は 3 例判明した。3 例とも低出生体 重㸓で生後 3-5 時にLPEC 䒠施している。1例は他院 でPotts法で再手術されたが再々発、1 例は水腫で再発して再 LPEC 時に結禁糸の緩みを認め、1 例は術直後から鼠径部の膨 隆が再燃したが経過観察で消失した。対側発生は初回手術時に 対側の開存なしとした 2 例と対側開存放置例 20 例中 3 例に出現 した。【考察】LPECでの再発は従来法と同等以下で、門老 確実に閉鎖すれば囊を離断せずとも問題ない。低出生体重児は 鼠径管が短く、門の径が大きく内・外鼠径輪が重なり直接へル 二ア状能になると考える 対敗発生の予湘は不可能で、IPEC では対側の開存は全例閉鎖してもいいと考える。

\author{
PD12-3 小児鼠径ヘルニアに対するLPEC法の適応拡大 \\ 々限界 \\ 徳島大学病院 小览外科 . 小览内視鏡外科 \\ 石橋広樹, 森大樹, 横田典子, 島田光生
}

小児外鼠径ヘルニアに対してはLPEC法を標準術式とし、病態 に応じて適応を拡大し、手技を追加、全夫して、従来法にコシ バートすることなく、全て腹腔鏡下に手術を行っている。今回、 LPEC 法の適応拡大として、Advanced LPEC 法とAYA世代 に対するLPEC法について検討したので報告する。【対象】 2005年から現在までに、1,277例 (男807例、女470例) の LPEC 法を施行した。AYA世代 (15歳以上) の症例も15例 (15-42歳) あった。内鼠径輪が開大している外鼠径ヘルニア 8例、内鼠径 ヘルニア 3 例、再発外鼠径ヘルニア 5 例の計16例に対して Advanced LPEC 法を施行した。【手術手技】AYA世代症例はへ ルニア分類 1-2 までを適応として、2 重結紮でLPEC法を行 なった Advanced LPEC法は、ラパヘルクロージャーを用い て腹横筋膜弓と ilio-pubic tractにU-state sutureをかけて縫縮 後，通常の LPEC法でヘルニア囊を閉鎖する。これを外側鼠径 裔 (再発外鼠径へルニア) で行えば内鼠径輪の縫縮ができ、内 側鼠径窩（内鼠径ヘルニア症例）で行えば鼠径管後壁補強が腹 腔鏡下に可能となる。【結果】術後成績では、再発を 3 例 $(0.2 \%)$ 、 SSI 3 例 $(0.2 \%)$ を認めたが、それ以外の合併症はなかった。【結 語】小児鼠径部ヘルニア疾患に関しては、LPEC法およびAd vanced LPEC法にて全て鏡視下に手術可能であり、AYA世代 にも適応拡大可能と思われ限界はないものと思われた。
PD12-4 LPEC 法の適応拡大 一トライフ病院 外科1), ハートライフ病院 ヘルニアセン

西原実 1,2 , 嵩原裕夫 ${ }^{2}$ ，国吉史雄 ${ }^{1,2)}$, 仲本正哉 ${ }^{1)}$, 泉家匠 ${ }^{1)}$ 野村寛徳 ${ }^{1}$, , 阿嘉裕之 ${ }^{1)}$, 宮平工 ${ }^{1)}$, 花城直次 ${ }^{1)}$, 奥島憲彦

くはじめに> 当センターでは、小児外鼠径ヘルニアに対する LPEC法の限界はない。成人に対してはTAPP法を第一選択術 式としているが、年齢、ヘルニア形態、ADLを評価し超高齢 者にも LPEC 法とその変法 (Advanced LPEC) を行っている その手技と成績を報告する。<対象＞2013年から2019年1月 までにLPEC法を施行した症例は123例 (男性102例、女性21例)。 男性：16 - 39歳 (33例) ではLPEC31例、TAPP+LPEC2例、 40 - 64歳 (35例) では LPEC14例、TAPP+LPEC21例、6584歳 (25例) ではLPEC11例、TAPP+LPEC14例、85-97歳（9 例) では LPEC5例、TAPP+LPEC4例。女性 : 16 - 38歳 (16例) ではLPEC16例、40-64歳（3 例）ではLPEC3例、65-75歳 (2 例) ではTAPP+LPEC2例 －結果とまとめ> 再発が40 歳と29歳と81歳の男性 3 例に見られた。これらの症例ではへル ニア門の辺縁が不明瞭な所謂”滑り台状”の形態を呈しており、 かかる症例では IP tractが確認できる症例にヘルニア門の外側 と後壁を補強する Advanced LPEC(IP tract repair) を行い再 発は見ておらず、成人症例への適応を拡大している。

PD13-1 肝細胞癌に対する肝移植の腫瘍条件の再考： ミラノ基準からの適応拡大の是非

福島県立医科大学 肝胆膵・移植外科

丸橋繁，木村隆，見城明

肝細胞癌に対する肝移植の腫瘍条件は、1996年に提唱されたミ ラノ基準（単発 $5 \mathrm{~cm}$ 以内、 3 個 $\mathrm{x} 3 \mathrm{~cm}$ 以内、脈管侵襲/遠隔転 移なし) がUNOSの適応基準となり、これまで日本における 生体・脳死肝移植の保険適応基準となっていた。一方で、個数 や最大径を用いた腫瘍条件の評価は連続的なものであり、 UCSF 基準 (2001)、Kyoto 基準 (2009)、Up-to- 7 基準 (2009) などが次々と提唱・評価され、腫瘍条件の拡大が進んできた。 日本のデー夕解析の結果、5-5-500基準 (5 個以内、 $5 \mathrm{~cm}$ 以内、 AFP500以下、遠隔転移/脈管浸潤なし) が提唱され、2019年 8 月から日本での脳死肝移植適応基準となった。この腫瘍基準 は、移植後再発のリスクとレシピエント候補およびドナー肝供 給数の条件により考えられるべきものであり、時代と共に修正 されて良いものである。

術前に移植後の肝細胞癌再発可能性を予測するには、実際には CTやMRIを用いた画像診断による条件（個数、大きさなど） と血液検查から得られる腫瘍マーカーなどの情報に限られる。 modalityによる診断精度の違い、術前治療による画像診断条件 の取り扱いや腫瘍マーカーの変動・測定誤差を考えると、簡易 から正確な再発予測診断には限界がある。

従って、現時点で得られたデー夕を基に、再発率予測を基準と して、腫瘍条件を拡大する方法は妥当なものであると考える。 一方で、基準のV Validation と脳死肝移植優先スコアの見直しが 定期的に行われなければならない

\section{PD13-2 \\ 肝細胞癌に対する肝移植適応基準（5-5- \\ 500基準)：全国集計結果から \\ 北海道大学病院 臓器移植医療部 \\ 嶋村剛}

肝細胞癌に対する肝移植の適応基準として1996年策定の Milan 基準が長く用いられてきた。一方、同基準を逸脱しても良好な 予後が得られる症例も多く、基準の拡大が模索されている。今 回、わが国の全国集計結果から新たな商応基準について検討し た。対象・方法：全国44施設における1998年から2009年までの 肝細胞癌に対守る生体肝移植1122例 (2011年集計) のうち検討 適格965例（ミラノ基準内664、基準外301）を検討対象とした。 こ㧈らを用い 5 年再発率 $10 \%$ 以下５年生存率 $70 \%$ 以上を担保 しつつ適応患者数が最大となる条件を解析した。最大腫瘍径は $5 \mathrm{~cm}$ に設定し、腫瘍個数・AFP・PIVKAIIのカットオフ值に より再発率を求めた。結果：腫瘍径 $5 \mathrm{~cm}$ 以下・腫瘍個数 5 個以 下でAFP $500 \mathrm{ng} / \mathrm{mL}$ 以下の時 $(5 X 5 X 500$ 基準) に適応症例数 が最大の725例となった。 $\mathrm{X} 5$ X500基準を満たす症例の 5 年再 発率は7.4\%、5 年生存率は75.8\%であった。Milan 基準内664例 （5 年再発率7.5\%、5 年生存率75.3\%）に対 L、Milan 基準もし くは5X5X500基準を満たす症例数は792例（5 年再登率9.1\% 5 年生存率 $74.8 \%$ ）となり、適応患者数は Milan基準よりも 19\%拡大した。結語：今後の Validationが必要だが、わが国の 現状に則した妥当な拡大基準と考えられる。 
岡山大学，小児外科

広島大学 消化器 $\cdot$ 移植外科

大平真裕, 今岡祐輝, 佐藤幸毅, 田口和浩, 黒田慎太郎, 田原裕之, 井手健太郎，小林剛，大段秀樹

背景：拡大ミラノ基準として 5-5-500基準が提唱され、保険 適応に向けて準備が進められている。当科の症例で、 $5-5$ -500基準の成績、再発予後因子、移植前治療の意義について検 討を行った。

方法：対象は2000年 1 月から2013年12月までの HCCに対する 肝移植症例104例を対象とした。5-5-500基準での背景比較、 無再発生存率の検討、再発予後因子の検討、移植前治療有無に よる移植後成績を検討。

結果: $5-5-500$ 基準内は85例、基準外は19例。基準外は、有 意に術前治療回数が多く (4.8 vs 1.7) 回、術後の腫瘍個数 (5.1 vs 1.6) 個、腫瘍径 (3.0 vs 1.9) cm、脈管浸潤 $(42.1 \%$ vs 16.5\%）が多かった（p<0.05）。5-5-500基準内・基準外の 5 年無再発生存率は、70.5\% vs $26.3 \%(\mathrm{p}<0.001)$ 。移植前治療 74 例、無治療30例は無再発生存率有意差なし。無再発生存に寄 与する独立危険因子は、5-5-500基準外とドナー年齢45才以 上であった（Cox比例ハザードモデル， p<0.05）。-5-500基 準内、病理学的ミラノ基準外の症例に㧧いて NK療法が無再発 生存率を上昇させていた。

結語：当院においても5-5-500基準は有用であると考えられ た。ミラノ基準外に対する NK 細胞療法の HCC 再発抑制が示 唆された。

PD13-4 生体肝移植拡大基準における京都基準と 5-5 -500基準の有用性の検証

京都大学 肝胆膵移植外科

海道利実, 加茂直子, 伊藤孝司, 穴澤貴行, 八木真太郎, 秦浩一郎, 田浦康二朗, 上本伸二

【目的】2019年 8 月より脸死肝移植における肝細胞癌（以下、肝癌） 移植適応がミラノ基準内または 5-5-500基準内に改定されたが、 生体肝移植に招ける肝癌肝移植適応は依然としてミラノ基準内て ある。今回、生体肝移植拡大基準として、「ミラノ基準内または 5 - 5-500基準内」と「ミラノ基準内または京都基準内」の成績と適 応症例数につき検討した

【方法】対象は1999年2月から2018年12月まで当科で肝癌に対し 生体肝移植を施行した233例。1) ミラノ基準、5-5-500基準、 京都基準内症例数、2) 各基準内生存率. 再発率、3) 3 ) $5-5$ -500基準内またはミラノ基準内」症例ならびに「ミラノ基準内ま たは京都基準内」症例の生存率・再発率、につき比較検討した。 【結果】 1) ミラノ基準内133例 (57\%)、5-5-500基準内165例 (71\%)、京都基準内179例 $(77 \%) ２ ＼mathrm{~ ） ~ ミ ラ ノ 基 準 内 症 例 、 5-5 ~}$ -500 基準内症例、京都基準内症例 $の$ 移植後 5 年生存率は、80\%、 $79 \% 、 81 \%$ 、同 5 年再発率は $6 \% 、 7 \% 、 7 \%$ と、ほほ同等のアウ 卜カムで京都基準内が最も多くの症例数。3) 5-5-500基準内ま たはミラノ基準内症例 $(\mathrm{n}=172)$ 及び京都基準内またはミラノ基 準内症例 $(n=195)$ の肝移植後 5 年生存率は、ともに79\%、同 5 年再発率は7\%、9％とほほ同等のアウトカムで京都基準内がょ 多くの症例数。

【結語】京都基準の方が、5-5-500基準に比べ同等のアウトカム でより多くの症例を生体肝移植適応とすることができ、有用であ る。

PD14-1 小児先天性胆道拡張症に対する腹腔鏡手術にお いて膵盟管合流部を視覚化するために

長崎大学病院小览外科

山根裕介, 吉田拓哉, 田浦康明, 小坂太一郎, 江口晋, 永安武

【目的】当科では先天性胆道拡張症（CBD）に対して2013年よ り腹臆鏡手術 (Lp) を導入した。初期の 2 例で展開不良・膵 胆管合流部 (PDJ) の視認不足が原因と思われる膵内胆管 $(\mathrm{IpD})$ の遺残を経験した。以後、IpDの処理時には膵実質を十分に展 開し、視野の確保に努めている。今回、PDJの展開に関する検 討を行つたので報告する。【方法】2013年から2018年の期間で 上記の 2 例を除外した Lp症例を対象に手術ビデオを見直し、 PDJ 視認時の展開良好群 $(\mathrm{A})$ と展開不良群（B）の二群間で 術前背景、周術期の成績に関して後方視的に比較検討した。【結 果】対象期間中にLp：16件が施行された。A群：12例、B群 4 例であった。6 例 $(38 \%$ 、A群 : 5 例、B群 : 1 例) で術前 ドレナージを要した。B群は全例、術前に膵炎の既往があり、 $\mathrm{A}$ 群と比較し、有意に AMYの最高值が高值（A群：1123.5 IU/1、B群：298 U/1) であった。手術時間はA群：369.7分、B 群：327.8分と有意差を認めなった。IpD剥離に伴う周術期合併 症を認めなかった。IpDの遺残に関しては、無鎮静でMRCPが 施行可能な小学校就学前後での検査計画としているため、6 例 (A 群：5 例、B群：1 例、38\%) にとどまっているが、IpD の遺残を認めていない。【結語】Lpでは、開腹手術と異なり視 野が接線方向となるため、膵実質を展開しなければPDJを視 認することは難しい場合もある。展開を十分に行うことでPDJ を視覚化できると考えられるが、膵炎既往症例に対する対応が 今後の課題である。
野田卓男, 谷本光隆, 納所洋, 宮田将徳, 谷守通

先天性胆道拡張症（本症）の手術は、可能な限り肝外胆管を切 除し胆道再建で吻合部狭窄をきたさないことが必須である。従 来の開腹による術式と最近行っている鏡視下手術を検討し、本 症小児例に対古る術式の妥当性と今後の課題を考える。【開腹】 膵側総胆管の剥離は小さな血管でも出血が多く丁寧な結紮が必 要である。膵内胆管の処理は、術中造影によるマーキングや術 中胆道鏡 (膀胱鏡使用) で膵管との合流部を同定して行う。肝 側胆管は左右肝管合流部で切離し、左右肝管側壁に5〜10 $\mathrm{mm}$ の割を入れ吻合口を拡大する。肝門部肝管一空腸吻合は Schmieden法による連続縫合を行う。【鏡視下】ポートは臍部 と左右側腹部、右肋弓下の 4 か所に挿入。右肋弓下より胆囊を 引き出して術中胆道造影を行う。膵側総胆管の剥離は、主にフ ック型錐子を使用守るがほとんど出血しない。膵内胆管の処理 時に、内視鏡などは行っていない R-Y脚は空腸を臍部から 引き出し腹脘外で縫合する。肝側胆管の処理は開腹と同様に施 行できるが、吻合は結節縫合を行っている。【考察】従来の開 腹手術と同等以上の成績が得られれば、小児でも鏡視下手術の メリットは大きい。肝門部肝管を形成する手技は鏡視下でも可 能で、総胆管の剥離は膵内胆管も含めて鏡視下の方が出血が少 ない。脺側総胆管の処理には、ポートを追加して胆道内視鏡を 行うなどの工夫が必要である。また、巨大な胆道拡張症は開腹 で行うのが妥当である。

PD14-3 先天性胆道拡張症のおける開腹手術と腹腔鏡手 術の違い

兵庫県立こども病院 小児外科

福澤宏明, 黑田靖浩, 藤枝悠希, 植村光太郎, 竹内雄儫, 鮫島由友, 河原仁守, 森田圭一, 岩出珠幾, 横井暁子, 前田貢作

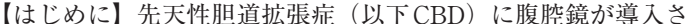
れ各施設で施行されてきている。開腹・腹腔鏡どちらが適して いるかを検討する上で、当院の両術式の現状を調べた。【対象・ 方法】腹腔鏡を導入した 2012 年以降の CBD症例を後方視的に 調べ、それ゙れの術式の状況を検討した。【結果】当該期間に 開腹手術が24例、腹腔鏡手術が13例施行 (開腹移行 1 例) され ていた。開腹手術の内10例は胎児診断、灰白色便、脸出血で見 つかっており、いずれも乳児期早期に手術が施行されていた。 一方、腹腔鏡は全例高アミラーゼ血症を伴う腹痛で発症してい た。手術時期・手術時体重は開腹が1.09歳・8.8kg で腹腔鏡が 5.99 歳・14.kg で年長児に腹腔鏡が施行されていた。手術時間 は開腹363分、腹腔鏡459分で腹腔鏡が長かった。逆に術後経口 摄取開始・在院日数は開腹 3 日・ 8 日、腹腔鏡 2 日・ 5 日で腹 腔鏡が短かった。術後合併症は開腹で 5 例（胆汁ろう2例、乳 び腹水 2 例、イレウス 1 例) で、多くは乳览手術例であった。 腹腔鏡は合併症を認めていない。【考察】腹腔鏡手術は比較的 大きい児に施行されており安全に施行できている。開腹手術は 乳児期早期のような手術が難しい児に選択され、そのため合併 症・長期入院につながっていると考えられた。【考察】腹腔鏡 は年長児の状態の良い患児には良い適応である。逆に乳児期早 期のような比較的難しい症例は開腹手術を選択し、無理な腹䏶 鏡手術での合併症は避けるべきである。

PD14-4 小児先天性胆道拡張症の根治術を考える（開腹 アプローチの立場から) 徳島大学病院 小览外科 - 小坚内視鏡外科 石橋広樹, 森大樹, 横田典子, 島田光生

【背景】当科の小児先天性胆道拡張症 (CBD) の手術は、開腹で、 肝外胆管切除 (肝管空腸吻合術) を行っている。腹腔鏡手術の 導入に関しては、当科の症例数が非常に少ない（1例/年程度） ことと、膵内胆管を遺残なく確実に切除および肝内胆管狭窄の 処置に腹腔鏡では不安があり、導入に至っていない。今回、当 科の CBD 症例を検討し、後方視的に腹腔鏡手術が可能性も検 討したので報告する。【結果】2011年からのCBD症例は 7 例 (男 2 例、女 5 例) で、2 歳未満が 4 例 (全て戸谷IVa) で、残り は11歳 (戸谷IVa) と12歳が2 例 (戸谷Ic) であった。2歳未 満の 4 例は $5 \mathrm{~cm}$ の開腹創で、年長児の 3 例は $9 \mathrm{~cm}$ の開腹創で手 術を行った。2 歳未満の 4 例は、全例で肝内胆管の狭窄があり、 全例で胆管形成を必要とした。巨大総胆管拡張の 1 例では、脺 管を損傷があり、脺管形成、膵液ドレナージを必要とした。年 長览の 3 例では肝内胆管狭窄は認めなかったが、12歳の戸谷Ic の症例は、合流部が十二指腸に非常に近かったため、膵臓内の 膵内胆管の掘削に苦労した。術後合併症は 1 例もなかった。後 方視的にみても、2 歳未満の5例に関しては、腹腔鏡手術は困 難であると考えられたが、年長児の11歳 (IVa型) と12歳 (Ic 型) は腹䏶鏡手術は可能と思われた。【考察】乳幼览のCBD症例で は、 $5 \mathrm{~cm}$ の開腹創で確実な手術が可能であり、腹腔鏡手術のメ リットは見出せないが、年長児では症例を選択して腹腔鏡手術 も導入すべきと思われた。 
vasive esophagectomy の現状

浜松医科大学 外科学第二講座

竹内裕也

食道癌に対する胸沿鏡下食道切除術は、機器の進歩や手術手技 の向上に伴い、近年急速に普及が進えでいる。2011年の NCD では、食道切除再建術における内視鏡手術の割合は $31 \%$ であつ たが、2017年では56\%と初めて5 割を超えた。胸腔鏡下食道切 除術は、胸壁破壊を最小限に留めることによる低侵襲性と拡大 視効果による精緻な手術操作が期待されるが、その安全性、有 効性に関する十分な結論は現時点では得られていない。 NCD を用いた開胸手術と胸腔鏡下手術の比較検討やメタアナリシス の結果、短期成績は画群でほぼ同等であることが報告されてい る。とくに胸膑鏡下手術により術後呼吸器合併症が軽減される 可能性が指摘されている一方で、外科的な合併症は胸哚鏡下手 術で多くなることも報告されており注意が必要である。長期成 績についてはとくに扁平上皮癌において患者生存に寄与する十 分なエビデンスは得られておらず、現在多施設共同ラシダム化 比較試験（JCOG1409）が遂行中である。本試験は、cStage I-III胸部食道扁平上皮癌を対象に、胸腔鏡下手術の長期予後 非劣性を検証する第III相試験であり、同時に術後呼吸機能変 化や患者 QOL 評価を行うことで、胸腔鏡下食道切除術の安全 性、有效性を明らかにする成果が期待されている。一方、縦隔 鏡下アプローチやロボット支援下手術も保険収載され、新たな アプローチ法として注目されているが、安全性と有効性に関す る十分な配慮と検証が必要である。
PD15-4 開胸手術のメリットとデメリット 一当科にお

ける低侵襲化を目指した閏胸手術の試み

千葉大学大学院医学研究院先端応用外科学 村上健太郎, 豊住武司, 上里昌也, 松原久裕

【背景】これまで当科では胸肤鏡下手術を採用しておらず、一 貫して標準治療である開胸手術の低侵襲化に取り組んできた。 開胸手術のメリット・デメリットおよび当科における開胸手術 の試みについて概説する。【開胸手術のメリット】胸腔鏡手術 に対する開胸手術のメリットとしては、第一に直接的な触覚が 使えることであり、視覚だけでは切離ラインの設定が難しい高 度に瘏痕化した救済手術症例や、bulky tumor症例などに大き な恩恵をもたら卞。その他にも手術操作の自由度が比較的高い こ様々な角度からの視野をスコピス下に依存せず容易に得 られること、出血時の対応が容易であることなどが挙げられる。 【開胸手術のデメリット】開胸手術のデメリットとされる胸壁 破壞に伴う高い侵襲性であるが、当科では胸壁の筋肉を温存し たVertical Muscle-Sparing Thoracotomyを採用し、胸壁破䁾 を最小限に留めている。また当科では頸部操作と腹部操作を先 行した後に胸媣操作を行っているが、可及的に頸部と腹部から 縦隔郭清を行うことにより、胸部操作時間の短縮を目指してい る。これらの工夫に上り SIRSが0.5 \pm 0.7 日短期間に抑えられ ていた (Okazumi 2004)。【まとめ】当科に打ける開胸食道癌 手術手技の工夫を概説した。開胸手術でも安全かつ短時間に手 術を終えることで低侵襲性が得られると考える。
PD15-2食道外科手術における胸腔鏡の拡大視と開胸の 術野展開イメージの融合

安田卓司, 白石治, 岩間密, 加藤寞章, 平木洋子, 安田篤, 新海政幸，木村豊，今野元博

【背景】食道癌に対する胸胫鏡手術は近年急速に普及したが、 その低侵襲性に関しては客観的なエビデンスがない。胸胅鏡手 術と開胸手術は対極として扱われるが、アプローチが異なるだ けで手術内容は同じである。【各手技の特徵】胸腔鏡の最大の 利点は拡大視による精細な手術で、開胸に関しては全体像の把 握から得られる自由度高い術野展開である。【我々のコンセプ 卜1 1. 開胸の有無や腫瘍進行度にかかわらず胸㒄鏡の拡大視 は必須で、特に進行癌や salvage等剥離層の同定が困難な症例 ほど有用である。なぜなら剥離の可否は占と占の勝負で直視で 見えない角度からでも術野の桩大視画像の提供ができ、確穾か つ安全な操作が可能だからである。2. 全体像把握と様々の角 度からの術野展開の修得 (ス夕ッフの教青指導) に開胸での修 練が必要。3.但し胸腔鏡画像下の手技で大開胸は不要である。 4.これらの基本に胸腔鏡手術独自の手技の修得が加われば手 術困難な症例まで適切から幅広い手術戦略の選択が可能になる と考える。【手術手技】 小開胸下胸哚鏡画像支援手術。1 . 約 $10 \mathrm{~cm} の$ 第 4 肋間前側方開胸、2. OLYMPYS VISERA ELITE II の3D 画像を使用。3．切離は bipolar scissors とメッ チェン。4.鉜子はGesiter ValveGateシリーズ。スタッフの 成熟と共に現在胸腔鏡手術手技へ展開中である。【結語】開胸 の術野展開イメージを基に胸䏕鏡の拡大視を最大限活用するの が食道手術の基本と考える。

PD15-3 胸部食道癌に対する標準術式としての胸胿鏡下 食道切除術 東北大学 消化器外科学

龟井尚, 谷山裕亮, 岡本宏史, 佐藤千晃, 高屋快, 今野卓朗, 氏家直人, 及川隆弘, 小関健, 鳩山恵一郎, 今野裕司, 安藤涼平, 篠崎康晴, 海野倫明

(背景) 胸望鏡下食道切除、縦隔リンパ節郭清術が開始されてから 20 年以上が経過し、その間、各施設で術式の工夫、変遷がありつ

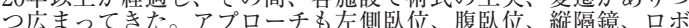
ットと様々であるが、2017年には全手術の56.1\%が胸㓐鏡手術と なっている。(低侵襲性) 当初、体壁破壞を最小限にした低侵襲性 は、縦隔郭清の高度侵襲を超えてのメリットは見いだせなかった が、現在最も多く行われている腹臥位十人工気胸手術では、自験 例を含め、肺合併症の軽減、出血量の減少、炎症反応の早期回復 など、低侵襲性が報告されている。(手術手技)一般的に手術時間 が長く、高度な技術を要するとされるが、拡大視とビデオの教育 効果は高い。適切な教育システムが重要である。緊急開胸のシミ ユレーションは必須である。(短期成績) 反回神経麻癘、縫合不全 などの肺以外の術後合併症の頻度は同等である。鏡視下群で再手 術が多いとされるが、詳細は不明である。再手術が多いとしても 30日死亡率は両者に差はない。(長期成績) 胸胿鏡手術は開胸手術 に比べて、同等もしくは良好な長期成績が報告されている。自駼 例でも術前治療例を含む寺心゙てのステージにおいて 3 年、5 年生 存率は全国集計より良好な成績であった。（結論）成績は良好、も しくは同等で、低侵襲性を享受できる胸沿鏡下食道切除術は、胸 部食道癌の標準治療として、術前治療例を含めてほほす心ての症 例に施行されるべきである。
PD15-5低侵襲性と根治性を目指した縦隔鏡下食道切除 術の工京都府立医特色学 消化器外科

小西博貴, 藤原齐, 塩崎敦, 庄田勝俊, 小菅敏幸, 窪田健, 有田智洋, 森村玲, 村山康利, 栗生宣明, 生駒久視, 中西正芳, 岡本和真, 大辻英吾

（はじめに）食道癌根治切除は高侵襲な手術で、胸腔鏡による低侵 襲化が進められているが、再手術増加などの問題も報告されてい る。当科では経胸手技や片肺換気の回避による低侵襲化をめざし、 緥隔鏡下食道癌根治切除を導大している。(工夫・手技）全例て 3D-CTを撮影し、気管支動脈走行や解剖学的変異を確認。術中反 回神経モニタリング施行のため短時間作用型の筋弛緩薬で道入 頚部単孔アプローチと経裂孔HALS操作で非開胸下に食道全長を 授動・郭清するが、裂孔操作は完全腹胿鏡下にも施行可能である。 気管支動脈・ 奇静脈弓・胸管は温存し、郭清上必要な場合のみ合 併切除。気管分岐部郭清は通常䅡部アプローチで行うが、経裂孔 的にも可能である。維隔胸愺は温存するが、合併切除など完全非 開胸にはこだわらず、胸膜切除時も胸柼ドレーンは留置しない 経腸栄盖チューブはイレウス発生を懸念し胃管前庭部から留置。 (特色) 経胸切除で最深部となるNo.106tbl, 112郭清は、視野や到 達性も良く正確に郭清範囲決定が可能。出血量や手術時間は大幅 に減少し、当日手術室で抜管LICU帰室。術後疼痛管理も良好。 肺合併症の頻度は減少し、胸水眝留は起こるが2回までの穿刺て の改善が多い。他の合併症には他術式と差異を認めない。(結語) 縱隔鏡下食道切除による経胸操作・片肺換気の回避や手術時間知 縮は、肺合併症低減など低侵襲化につながり、中長期予後や再発 について今後の検討が必要である。

PD15-6進行食道癌における胸腔鏡手術の限界と開胸移 行の判断に関する検討

大阪大学消化器外科

田中晃司, 山崎誠, 牧野知紀, 山下公太郎, 西塔拓郎, 高橋剛, 黑川幸典, 中島清一, 土岐祐一郎

胸腔鏡手術は胸壁破壊の軽減による手術の低侵襲化、拡大視効 果による精度の高いリンパ節郭清などの利点があり、保换収載 後急速に普及が進んでいる。当科では、胸腔鏡導入当初は、 T4、多発りシパ節転移、salvage症例は対象外としていたが、 近年は症例に応じて、開胸移行を視野にいれつつ胸腔鏡下にて 手術を開始している。そのため、体位は左半腹臥位とし、開胸 移行が必要となればベッドのローテーションにより左側卧位の 体位が取れるようにしている。胸腔鏡手術の利点は 1 。下縦隔 の操作が行いやすい、2，拡大視効果による至適な剥離層を認 識しやすいことがあげられる。一方、胸腔鏡手術では鉗子の角 度が大動脈とは接線方向になりやすく、適切な剥離操作が行い にくい場面があった。損傷時のリカバリーに関しては、T4の 対象臓器が気道系の場合、膜様部損傷が生じることがあるが、 胸腔鏡下での修復は比較的行いやすい。二方、大動脈や大血管 の場合は、大量出血そのもの、および血液の吸引操作による肺 の膨張が視野不良を引き起こし、一時止血が困難となり致命的 な状況になりうるため、ためらいなく開胸移行することを念頭 に置く必要があると考えている。今回、T4食道癌の診断にて、 術前治療後 borderlineT4の症例に対して、胸腔鏡下で手術を開 始し、胸胿鏡手術が完遂できた症例と、開胸移行した症例の動 画を供覧する。 
PD16-1

術成績

札幌医科大学 呼吸器外科学

宮島正博, 進藤悠馬, 新井航, 高橋有毅, 多田周, 渡辺敦

【背景】ロボット支援下縦隔腫瘍切除は2018年度より保険適応 となつた。しかしロボット支援下胸腺腫胸腺摘出術の報告は少 ない。今回、当院におけるロボット支援下胸腺腫胸腺摘出術の 手術成績を検討した。【対象と方法】2018年10月から2019年 6 月までに当科で施行した縦隔腫瘍を伴うロボット支援下胸腺腫 胸腺摘出術 6 例を対象とした。【結果】男性 4 例、女性 2 例。 年歯中央值は50歳 (34-77歳)。1例に重症筋無力症を合併。腫 瘍の局在は前縦隔正中が 5 例、左前縦隔が 2 例。腫瘍最大径 中央值は26mm (11-45mm)。体位はアプローチ側を30度程度挙 上した仰臥位で、右アプローチが 4 例、左側アプローチ2例で あった。全例で 1 ケ所のアシストポートを置き、人工気胸、気 縦隔下にdaVinci Xiを使用し3armで行った。手術時間中央佔 は162分（136-224分）、ンソール時間中央值は110分 (85-175 分)。出血量中央值は $10 \mathrm{ml}(5-50 \mathrm{ml})$ 。病理診断は胸腺腫 5 例、 悪性リンパ腫 1 例 (永久標本) であった。胸腔ドレーン留置期 間中央值は 1 日 $(1-2$ 日)、術後在院日数中央値は 6 日 $(5-$ 8 日)全例で術後合併症を認めなかった。【結語】ロボット支 援下胸腺腫胸腺摘出術では狭小空間においても良好な視野が確 保でき、多関節を有する鉬子により精緻な操作を行うことが可 能であった。今回、我々がこれまで行ってきた鏡視下アプロー チによる胸腺腫胸腺摘出術と比較検討し、実際の手術手技とと もに報告する。

PD16-2 臨床病期I期非小細胞肺癌に対する前方アプロ ーチによるロボット支援下肺葉切除の実践

九州医療センター 呼吸器外科.

庄司文裕, 山崎宏司, 上妻由佳, 豊川剛二, 竹尾貞徳

【背景】ロボット支援下肺葉切除術のカメラ位置は基本的に見 上げである。一方、開胸・ハイブリッド手術・対面式胸腔鏡手 術は前方 (腹側) ・後方 (背側) からの視野である。我々はカ メラ視野を対面式にした前方アプローチによるロボット支援下 手術に取り組んでいる。【対象及び方法】(対象) 2018年 5 月か ら2019年 6 月にかけてダヴィンチサージカルシステム (Si) を 用いて肺葉切除を施行した臨床病期 I期非小細胞肺癌35症例。 内訳：性別:男/女 $=19 / 16$ 、平均年歯令67歳 $(35-83)$ 、組織型:腺 癌 / 扁平上皮癌 $=33 / 2$ 、臨床学的 $\mathrm{T}$ 因子: $\mathrm{T} 1 \mathrm{a} / \mathrm{T} 1 \mathrm{~b} / \mathrm{T} 1 \mathrm{c} /$ $\mathrm{T} 2 \mathrm{a}=9 / 16 / 7 / 3$ (方法) 側臥位で患側の肩・上腕・腰部を 保護。第 4 肋間中腋窩線上にカメラポート、第 3 胁間腋窩、第 6 肋間後腋窩線上、第 $6 \sim 9$ 肋間のポートは自動縫合器の角度 を考慮して位置を決定。最尾側のポートはポートイシポートで 助手のアシストポートとして利用。ペイシェントカートを背部 より垂直にロールイン、CO2送気にて術野スペースを確保。【結 果】術式:RUL/RML/RLL/LUL/LLL=13/1/9/5/7、コン ソール時間：平均 131 分、手術時間：平均 212 分、出血量：平均 $52 \mathrm{~g}$ 、開胸・胸腔鏡への移行なし、術後胸腔ドレーン留置期間 平均 15 日、Clavian-Dindo 分類 II 度以上の合併症：なし/あり $=32 / 3$ 。病理病期:IA1/IA2/IA3/IB/IIA $=7 / 20 / 4 / 3 / 1$ 。【結 語】本法は左右全肺葉に安全に施行可能であり、ロボット支援 下肺葉切除術におけるアプローチの選択肢の一つになりうる。

PD16-3 呼吸器外科ロボット支援手術は第一選択となり 諏訪赤十字病院 呼吸器外科1), 長野市民病院 呼吸器外科2), 伊那中央病院 呼吸器外科 3

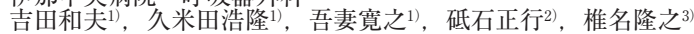

呼吸器外科領域でもロボット支援手術（RATS）が保険適応と なったがVATSとの住み分け、コスト面も含め課題も多い。我夕 の現在までの84例のRATSの経験より現状と展望について検 討した。【方法】2013-19年までのRATS症例（肺癌49例、前 縦隔腫瘍35例)につき周術期データ・コスト等につき検討した 術式は肺葉切除と胸腺全摘術（拡大含む）、前者は術者 2 人、 後者は 3 人により施行された。両群とも全例で肺葉切除は側臥 位 5 孔、胸腺全摘術は仰卧位右アプローチ、3-4 孔で施行し CO2送気を用いた。【結果】肺癌で全例臨床病期 I 期、前縦隔 腫瘍は正岡 I-II期 (最大腫瘍径72mm) に対しRATSが施行さ れた。周術期データは両術式とも当科VATS例に比し同等以 上であったが、特に胸腺全摘術の手術時間は短かった。また、 後半21例以降の症例では、前半 (〜20例) に比しコンソール 時間、入院期間は短縮し、出血量も軽減傾向にあった。ドレー ン留置、在院期間も同様でこの傾向は前縦隔腫瘍例ではより顕 著だった。コスト面でも後半では使用鉗子本数を減らすなど手 技の簡略化を行ったこともあり、VATSの同術式に比較し5 -10万円前後の減益にとどまった。【考察】RATSの手術操作に おける優位性、ラーニングカーブの早さが示唆され、コスト面 でも許容範囲と思われた。手術適応においてもVATSと同様 と考えられるため、今後有資格者の増加、機器の普及等により 当該術式の第一選択手技となりうる可能性があると思われた。
PD16-4 と今後の位置づけ

秋田大学 食道外科

本山悟, 佐藤雄亮, 脇田晃行, 川北雄太, 長岐雄志

我々は食道外科領域に対するロボット支援手術を2014年に導入 し、2019年 8月現在で46例に実施した。対象疾患は胸部食道癌 38例 (術前化学放射線療法 (CRT) 23例、術前治療なL15例)、 食道胃接合部癌 5 例 (術前治療 2 例、術前治療なし 3 例)、食 道アカラシア 2 例、食道粘膜下腫瘍 1 例である。食道癌手術に おいて胸腔鏡下食道切除術（TE）に対するロボット支援胸腔 鏡下食道切除術（RATE）の優位性を示すエビデンスは未だ十 分とは言えない。しかし、我々の報告 (Motoyama et al. Anticancer Res 2019) も含めて、上縦隔リンパ節郭清における郭 清強度の増加と反回神経麻痺率の減少が複数の施設から報告さ れている。現在、我々はRATEの適応を拡大し、術前CRT後 の局所進行食道癌 (T3.5) 手術、根治的 CRT 後のサルベージ 手術、背側胸部大動脈周囲リンパ節 $(112 \mathrm{aoP})$ 郭清手術など、 従来、TEでは対応が困難であった症例に対して積極的に寒施 している。また、食道胃接合部癌に対して、ロボット支援胸腔 鏡腹腔鏡下、下部食道切除および噴門部切除（胸腔内食道胃吻 合) 手術を実施している。TEの発展の過程をみれば想像に難 くないが、各種デバイスの開発と共に今後RATEが手術の質 の向上、手術時間の短縮、より精緻なリンパ節郭清、合併症軽 減に寄与し、急速な発展を遂げると思われる。さらにRATE はより高度な手術が求められる症例に対して適応が拡大されて ゆくと思われる。

PD16-5 食道がんに対する低侵襲性手術ーロボットは胸 腔鏡を凌駕するのかー

国立がん研究センター中央病院 食道外科1)，国立がん研究セ ン多一東病院 食道外科 2

大幸宏幸 ${ }^{1}$, 小熊潤也 ${ }^{1}$, 金森淳 ${ }^{1}$, 石山廣志朗 ${ }^{12}$, 平野佑樹 ${ }^{1)}$, 栗苗㚐資 1$)^{\prime}$, 藤笛武郎 ${ }^{2}$, 藤原尚志 2

各種固形がんに関して、開胸手術 (OPEN)から低侵襲手術 (MIS: Minimally Invasive Surgery) へとパラダイムシフトが起き OPENでの触覚の替りにMISでは因眼では確認できない視覚 を得ることが出来た。高解像度内視鏡で確認される解剖により、 外科解剖学は飛躍的に進歩し深く理解されるようになった。更 に、ロボットでは安定した3D高解像度カメラにより、微細解 剖が更に強調され確認する事が出来る (Robotically Enhanced Surgical Anatomy)。更にマスタースレーブ式多関節ロボット アームによる緻密な機能温存手術が可能になった。食道癌に対 するMIS : 胸腔鏡手術では肋間による可動制限を受けながら、 周囲臓器を損傷しないように神経機能を温存しながら全縦隔に 渡る精緻な手術が要求される。ロボットでは胸脘鏡の弱点を凌 駕するように、Robotically Enhanced Anatomyを認識しなが ら、より安全で神経機能を温存した根治的リンパ節郭清を伴う 精緻な食道切除が可能となる。2018年4月にロボット支援下食 道切除術は保険収載されたが、未だ普及率は低く全食道癌手術 の1\%にも満たない。しかし、食道がんに対するロボット支援 下手術は、胁間による強い制限を受ける限定された胸膑内で、 神経機能を温存した精維な手術を可能すると期待されている。

PD16-6 食道癌手術におけるロボット支援手術の位置づ 東京大学 消化管外科学 ${ }^{11}$, 国立がん研究センター中央病院胃 外科2), 三井記念病院外科 ${ }^{3}$

瀬戸泰之 ${ }^{1)}$, 愛甲承 ${ }^{1}$ ，八木浩一 ${ }^{1}$, 奥村康弘 ${ }^{1}$, 山下裕玄 ${ }^{11}$, 山形幸德2 $)^{\prime}$, 秝和彦 3

食道癌根治術は、侵襲の大きい手術として知られており、合併 症発生率がほぼ $40 \%$ と報告されている。特に、術後呼吸器合併 症、反回神経麻痺、縫合不全などの発生頻度が高く、また予後 にも影響することが知られている。よって、それら合併症の抑 制が契緊の課題となっている。2018年保険改定で、胸望鏡下食 道悪性腫瘍手術（K529-2）でもロボッ卜活用が認められ、食 道癌手術でも、ロボット支援手術が合併症抑制に貢献すること が期待されている。これまで、宇山らにより胸胿鏡下アプロー チでのロボット使用により、反回神経麻痺の発生頻度が減少す ることが報告されている。我々は、2012年より、経裂孔的にロ ボットアームを挿入し、気管分岐部や気管支リンパ節などの中 縱隔までの郭清を、非胸腔アプローチ(韭開胸) で行う術式を 開発し行ってきた。さらに、頸部創から縦隔鏡にて上縱隔郭清 を行うことによりささきのロボット手術との組み合わせで、片 肺換気なし、非胸脘アプローチによる食道癌根治術を行ってい る。これまで124例に対し行い、開胸術と比較し有意に術後呼 吸器合併症を減少できること、さらに術後QOLも良好である ことを報告してきた。ロボット手術の特性を活かし、今後、さ らに合併症抑制を目指すことが一義的位置づけと考える。また ロボット手術の付加価值をいかに活用していくが、今後の課題 になるものと思われる。 
膵頭十二指腸切除術は、術後膵液瘦の発生や $\mathrm{R} 0$ 手術の困難さ など、二例ごとに新しい問題が提起される高難度手術である。 開腹vsと鏡視下で異なる注意点もあれば、同じような問題に 直面することも多い。まず、Kocher授動術後の上腸間膜静脈 (SMV) まわりの剥離であるが、鏡視下ではSMVからの思わ ぬ出血に注意することが肝要で、鏡視下といえども左手での支 持のもと血管縫合系で止血守る技量を習得すべきである。胃結 腸静脈管を結紮・切離すると、いよいよ膵トンネリングである が、鏡視下の方が膵後面へのアプローチは容易である。開腹で はSMV腹側に近い小血管に注意して膵トンネリングを行う。 上腸間膜動脈 (SMA) 右側の膵頭神経叢第II部を郭清しながら、 下膵十二指腸動脈を結紮するが、開腹ではMesenteric approachが容易であるが、鏡視下では視野展開から難度が高く なる。鏡視下では膵銁部からアプローチするuncinate approachが採用されることが多い。本ディベートセッションで は、開腹と鏡視下の立場から討議が行われる。本邦では保険適 応の点で、リンパ節郭清を伴う膵頭部領域の㤟性腫瘍に対守る 鏡視下手術は今後の課題であるため、欧米のエビデンスの引用 が多くなるであらう。今後は欧米に頼るのではなく、本邦から 質の高いエビデンスが発信されることを期待するものである。

PD17-1 最新のエビデンスに基づいた膵頭十二指腸切除 術 - 開腹の立場から

奈良県立医科大学 消化器 · 総合外科

庄雅之, 赤堀宇広, 中川顕志, 長井美奈子, 中村広太, 高木忠隆, 池田直也

【背景・目的】膵頭十二指腸切除術は未だに消化器外科手術に おける高難度手術であり，時として重篤な合併症あるいは転帰 を招く可能性がある。近年，腹腔鏡下手術の進歩および普及を 背景として，我が国においても，腹腔鏡下膵頭十二指腸切除術 (LPD) が保険収載された。実施に際しては，「当該手術につい て十分な経験を有する医師により実施され」, さらに「原則と して脈管の合併切除及びリンパ節郭清切除を伴わないものに対 して」と規定されている。本講演では，文献的エビデンスを元 に, LPD および開腹膵頭十二指腸切除術 (OPD) を比較検証し, 現状および今後の展望を検討孛る。【方法・結果】これまで LPCおよびOPDの比較を目的としたRCTに関する 3 編 (PLOT, PADULAP, LEOPARD-2）の論文が発表されている. RCT はインド，スペイン、オランダで実施され，各々 60 - 100例 のサンプルサイズであった。90日死亡, 重症合併症, 在院期間, 膵液漏, 術後出血, DGE等においていずれも術式’間に差はな かった。手術時間はLPDが有意に長時間であった。【結語】現 時点ではOPDに対するLPDの優位性を示すエビデンスはない． 低侵襲手術として期待されるLPDは今後膵癌等への適応拡大 も予想されるが, 安全かつ適切に実施されるためには, 術者お よび施設において, 多くの周到な準備が不可欠であると思われ る.

PD17-2 最新のエビデンスに基づいた膵頭十二指腸切除 術：鏡視下の立場から

愛知医科大学 消化器外科

深見保之, 有川卓, 大澤高陽，加藤翔子，鈴木健太，原田正晴， 松下希美, 戸田瑶子, 内野大輪, 倉橋真太郎, 松村卓樹, 齊藤卓也, 小松俊一郎, 金子健一朗, 佐野力

膵癌に対する腹腔鏡下尾側膵切除術（LDP）は短期成績において 開腹手術より優れており，再発率や予後などの長期成績も同等以 上であるとする報告が多く，本邦においても保険収載されている。 二方，腹腔鏡下膵頭十二指腸切除術 (LPD) についてはリンパ郭 清を伴わない症例に限定されているが,これらの成績を検討した うえで膵癌への適応拡大が行われていくものと考えられる。海外 からの報告では，膵癌に対するLPDは開腹手術に比べて出血量が 少なく術後在院日数が短く，R0切除率やリンパ節郭清個数には 差がないと報告されている。しかしながら，近年報告された LEOPARD- 2 試験ではLPD群の術後 90 日死亡率が有意に高い結 果となっており，LPDは膵切除と鏡視下手術の両者を積極的に行 つている施設 (チーム) で導入されるのが最低条件と言わさるを 得ない.

LPDの有用性については大規模前向き試験で明らかにされるべき であるが, LPDに習熟した膵臓外科医を増やすことは容易でない. 永川らはLPDの Learning curveについて検討し，30例で手技が安 定すると報告している (JHPBS, 2018)。当教室では胃・大腸・へ ルニアにおいてロボット手術を含む鏡視下手術の導入がされてお り 今後はPDに挍いて導入を検討している。若手外科医が開 腹膵切除を修練する必要がある中，いかに鏡視下 PD導入の準備 をすすめていくか, 教室の取り組みを紹介するとともに，最新の エビデンスに基づき鏡視下の立場で論議する。

PD17-3

膵頭十二指腸切除術一腹腔鏡およびロボットの

東京医科大学 消化器 - 小览外科学分野

永川裕一, 瀧下智恵, 刑部弘哲, 木谷嘉孝, 赤司昌謙, 西野仁恵, 勝又建次，土田明彦

近年, 米国やアジア各国の主要施設から腹腔鏡下膵頭十二指腸 切除術 (LPD) やロボット支援下膵頭十二指腸切除術 (RPD) など低侵襲 PD (MIPD) のの有用性が広く報告されている。経 験豊富なエキスパートからはMIPDの有用性が報告されている が, その難度は高く learning curve 中の安全性の確保が重要と なる。一方, RPDでは正確な縫合により脺液瘦減少が期待さ れたが現在のところは明らかではなく，創以外でMIPDにおけ る低侵襲としての有用性を高い科学的根拠をもって示す報告は ない。一方, 内視鏡外科やロボット外科における手術機器の著 しい技術発展により, 詳細な解剖学的構造を認識した䋐細な手

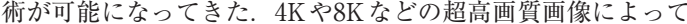
肉眼では認識することのできない構造物の把握は, あらたな手 術手技の開発に結びつく可能性がある。ロボット手術では手ぶ れを防止し高い自由度をもつた繊細な剥離, 縫合操作が可能に なってきた.デュアルコンソールは若手外科医への重要な教育 システムの一環になるだろう。これらの技術革新により将来の 手術はより安定した手術となっていくと考える。また医療分野 における deep learningやAIの今後の発展を考えると正確な術 中画像や手術操作のデータを蓄積していく上でMIPDは必要不 可欠となる、以上より，未来の外科の発展を考えると MIPDの 有用性を考える時期ではなく MIPDをいかに安全に導入し安定 した手術手技の開発に力を注ぐべき時と考える。

PD18-1 基礎研究の知見から考える術後合併症予防と早 期回復のための新しい試み

東京大学 手術部·侵襲代謝手術医学講座

深柄和彦, 東園和哉, 渡邊智記, 村越智

背景と目的：欧州臨床代謝栄養学会が提唱してきたERASは、 数々の周術期管理の工夫を組み合わせたパッケージであり、そ の導入により、再入院率を増加させないで術後早期退院と合併 症予防を可能にすることが多くの臨床研究で報告されてきた。 われわれは、ERASでこれまで示されていなかった、1）プレ ハビリテーションの効果、2）術前の低糖質高脂肪食の効果、 についてマウスを用いて検討してきた。今回、それらの基礎硎 究デー夕を示し、今後のより良い周術期管理のありかたを開発 する上での参考としたい。検討 1 : プレハビリテーショシが侵 襲時の生体反応に及ぼす影響マウスにトレッドミル走を 3 週間 行い、その後、腸管虚血再灌流を加えた。非運動群に比べ運動 群では、生存の改善、腸管傷害の軽減、腸管組織・血中の炎症 性サイトカイン值の低下が観察された。検討 2 : 術前低糖質高 脂肪食投与が侵襲時の生体反応に及ぼす影響マウスにラード主 体で高脂肪とした低糖質高脂肪食を 3 週間投与し、その後、腸 管虚血再灌流を加えた。標準食投与群に比べ低糖質高脂肪食群 では、腸管の NO (一酸化窒素) レベル・NO合成酵素発現が低 下し、腸管傷害が軽減、血中炎症性サイトカイン值低下、循環 動態改善がみられた。結論プレハビリテーション、術前の低糖 質高脂肪食投与は新しい周術期管理の重要なパーツとなる可能 性がある。

PD18-2 胃癌手術患者に対する当院の周術期管理の工夫 一ERAS と高齢者に対する包括的ケアプログラム— 静岡がんセンター 胃外科1), 静岡がんセンター 消化器外科 2 古川健一朗1), 日景允 ${ }^{1)}$, 神谷諭 ${ }^{1)}$, 谷澤豊 ${ }^{11}$, 坂東悦郎 ${ }^{11}$, 杉浦禎一2), 塩見明生 ${ }^{2}$, 寺島雅典1)

【はじめに】我々は非高齢者胃癌患者を対象としたERAS、抒 よび、高齢者を対象とした誤嚥性肺炎やせん妄の予防を目的と した術前プログラムの有用性を報告してきた。現在、高齢者に 対しては包括的なパスを作成しその有用性を評価している。方 法】ERAS 試験：20-75歳の胃癌患者を対象とし、Primary endpoint として術後合併症 CD IIIの閥値を $20 \%$ に設定した。 また、ERAS群と非ERAS群を、背景を調整して後ろ向きに比 較検討した。高齢者に対する肺炎予防試験とせん妄予防試験： 75歳以上の患者を対象とし、肺炎予防プログラムを行つた。ま た、せん妄予防試験として周術期にラメルテオンを内服した。 【結果】 ERAS試験：術後合併症発生割合は13/121（10.7\% 90\%CI 6.47-16.56\%) であり、ERAS プロトコールは安全に施 行可能であった。非ERAS群との比較では、術前炭水化物負荷 は術後の栄養状態改善や筋力維持には繋がらなかった。高齢者 に対守る試験：術後肺炎発生割合は 3/86 (3.5\%) であり、肺 炎予防プログラムは有用であった。術後せん妄発症割合は $4 / 76$ (5.3\%)であり、ラメルテオンの周術期内服は有用であった。【結 語】非高齢者に対してはERASパスが有効であったが、炭水化 物負荷の効果は確認出来なかった。高齢者に対しては嚥下機能 のスクリーニングと術前介入及びラメルテオンの予防投与が有 用であった。現在、非高齢者にはERASパスを、高齢者には包 括的ケアプログラムを導入している。 
PD18-3

当院における胃切除後の栄養指導と術後栄養状

態の検討

がん研有明病院

太田工ミ, 井田智, 幕内梨恵, 熊谷厚志, 大橋学, 布部創也,

佐野武

【背景】胃切除後の体重及び骨格筋量の減少はQOL低下や術後 補助化学療法の継続性に影響し、予後の悪化につながるとされ ている。体重や骨格筋量の隇少抑制を目的に栄養指導の効果に ついて検討した。【方法】2016年6月から2017年10月までに初 発胃癌に対し根治術を施行した658例 (年歯中央值66歳) を対 象とした。栄養指導の有無と術後合併症発生との関係、また術 前から術後 3 ケ月までの経時的なプレアルブミン（prealb）変 化率および体重減少率、骨格筋量減少率を比較した。栄養指導 は術後 1 週間、1 1 个月、3 万月目に施行し、同時に体組成を Inbody S10にて測定した。Clavien-Dindo 分類Grade ll 以上を 術後合併症有と定義した。【結果】全658例中、栄養指導有515例、 無143例であった。栄養指導有群で術後1 ケ月から３ケ月にか けての prealb 減少が有意に抑制されていた $(\mathrm{p}<0.01)$ 。栄養指 導の有無と術後合併症の発生には有意差を認めなかった $(\mathrm{p}=0.71)$ 。しかし術後合併症を生じた症例（157名）において 術前から術後 3 ケ月までの骨格筋量の変化率を検討したところ 栄養指導有群では、-2.26\%であったのに対し、栄養指導無群 でのそれは-9.25\%であり、栄養指導有で骨格筋量の減少が抑 制される傾向にあった $(\mathrm{p}=0.17)$ 。合併症無の症例では、栄養 指導の有無による骨格筋量の変化に差を認めなかつた。【結論】 術後の栄養指導は栄養状態の維持に寄与する可能性がある。と くに合併症を発症した症例での効果が期待される。

PD18-4 肝胆膵外科領域手術におけるimmunonutrtition を用いたERASの導入

千葉大学 臓器制御外科

鈴木大亮, 古川勝規, 吉富秀幸, 高屋敷吏, 久保木知, 高野重紹, 酒井望, 賀川真吾, 三島敬, 中台英里, 大塚将之

【はじめに】我々は，高度侵襲手術では immunonutrition(IN) が ERASの一要素として重要と考え,その効果を検討してきた。現在、 肝胆膵領域手術へのINを取り入れた ERAS導入へ向けパイロット 試験を施行中である。【対象と方法】(1) (RCT1) 膵頭十二指腸 切除術 (PD) 患者50名老対象, 術前 IN施行群 (A) と未施行群 (B) に分け，感染性合併症 (IC) 発生率, Clavien-Dindo 分類による 重症度を比較した( RCT2) 胆管切除を伴う肝葉切除術患者40多 を対象, IN施行群 (C) と未施行群 (D) に分け同様の比較を行 なった。(2) パイロット試験:ERAS要素を複数導入した60例を 検討した。術式はPD24例, DP9例, 肝葉切除術 5 例, 肝区域切除 術10例, その他12例. ERAS要素は, 腸管前処置無, 絶食期間短縮, 術前経口補水液投与, 術翌日からの早期経腸栄養 (PD), リハビ リ強化を導入さらに PDや胆管切除を伴う肝葉切除術などの高 度侵襲手術に扮いては術前INを行った。【結果】(1) (RCT1) IC 発生率が60\% (B群), 28\% (A 群) とA 群で有意に減少し, 合 併症重症度も有意に改善した。(RCT2) IC 発生率が75\% (D群), 40\%（C 群）とC群で有意に減少し，合併症重症度も有意に改善 Lた（2）合併症は14例 (GradeB以上の膵液漏 4 例, 胆汁漏 3 例, 乳糜 6 例, SSI3例) に認めたが, ERAS導入による合併症増加は 認めなかった。【結論】高度侵襲手術においては術前INがIC防止 に有用であり, 肝胆脺領域手術におけるINを取り入れたERASは。 十分に導入可能である.

PD18-5 肝移植術後早期回復における HMB投与の有用 性に関するランダム化比較試験

京都大学 肝胆膵・移植外科

加茂直子, 海道利実, 穴澤貴行, 伊藤孝司, 秦浩一郎, 田浦康二朗, 上本伸二,

【目的】肝移植患者は、骨格筋量低下や低栄養、活動性の低下 などを伴うことが多い。術後早期回復のためには筋肉量や筋力 の早期回復が必要である。こで我々は、成人肝移植患者を対 象として、筋蛋白合成促進・分解抑制作用などを有するヒドロ キシー $\beta$-メチル酪酸 (HMB) 配合飲料のサルコペニアやアウ トカムの早期回復に関するパイロット無作為化比較試験を施行 したので報告する。【方法】2017年3月月から2018年10月までに 当院で成人生体肝移植を施行した症例を、割付調整因子（男女、 年齢、術前筋肉量) に基づき、事前層別割付法にて投与群 (HMB 群) と非投与群 (対照群) にランダム化した。HMB群は術翌 日から30日間、同配合飲料を経腸または経口投与した。術後合 併症によりリハビリ介入が行えなからた症例を除き、HMB群 12例、対照群11例につき評価。評価項目は、1）患者背景、2) 術後菌血症発症率、血液生化学データ（肝機能、WBC、CRP など）、術後在院日数など、3）術後1、2 加目における骨 格筋量 (SMI)、握力の実測值。【結果】1) 年齢、男女比、血 液型不適合、MELD スコアなどは両群間で有意差を認めず。2) HMB 群が、有意に術後菌血症発症率低值 $(\mathrm{P}=0.043)$ 、術後 3 週目の WBC 值高值 $(\mathrm{P}=0.005)$ 、術後在院日数が短かった $(\mathrm{P}=0.028)$ 。3) HMB 群が、有意に術後 2 力月目の SMI高值 $(\mathrm{P}=0.04)$ 、握力高值 $(1$ 个月目 $\mathrm{P}<0.001 、 2$ 个月目 $\mathrm{P}<0.001)$ 。 【結語】肝移植後 HMB 投与は、術後早期回復に有用である。
PD18-6

膵頭十二指腸切除術における ERAS管理と Physical Aging(PA) scoreによる高りスク症例の抽出 聖マリアンナ医科大学 消化器・D般外科 小林慎二郎, 小倉佑太, 圭橋篤仁，片山真史，小泉哲， 大坪毅人

【緒言】膵頭十二指腸切除術（PD）のERASガイドラインは2012 年に発表されたが,当院では2010年から早期回復を目指した包括的 周術期管理を行い, 有意に合併症が低減し術後入院期間も短縮して きた。また,合併症や長期入院となる症例を予測する Physical A ring(PA) scoreを考案した当院の ERAS管理の成績について 報告守る。【ERAS】術前カウシセリング, 絶飲食期間の短縮（前日 夕まで固形食,術当日朝に飲水.1POD で飲水,2POD で流動物,3POD で粥) ドレーン早期抜去 (4POD), 早期リハビリ開始 (1POD) など.【PA score】187例を対象にした多変量解析を行い,リスク因

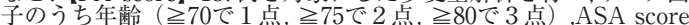

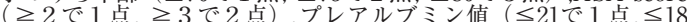
で 2 点) を合計.【対象と方法】2011年 4 月からのPD243例を対象 とし後方視的に検討. 全症例の術後経過およびPA score の低スコ ア群 (3点以内) と高スコア群 (4点以上) に分けて術後入院期 間と合併症発生率を比較。【結果】 243 例の術後入院期間中央值は 17 日自宅退院は $97.9 \%, 30$ 日以内の再入院は $1.2 \%$ 術後合併症発生率 はCD分類 gradII が $20.2 \%$,gradeIII 以上が9.9\%.PA score低スコア 群と高スコア群の比較では, 入院期間はそれぞれ15日と18 日,gradeII 以上の合併症は $23.3 \%$ と $30.3 \%(\mathrm{P}<0.01)$.【考察・結論】 PDにERASは有用だが,高齢,低采養,重篤な既往症は早期回復の リスクである.高リスク症例に対してはリハビリ強化や栄養管理の 工夫などが必要である

PD18-7 ERASの概念を導入したクリニカルパスと周術 期強化リハビリの運用は膵頭十二指腸術周術期管理に有用であ 和歌山県立医科大学 外科学第 2 講座

北畑裕司，川井学，廣野誠子，岡田健一，宮澤基樹，上野昌樹， 速水晋也, 小林良平, 須崎紀彦, 中森幹人, 中村公紀, 尾島敏康, 山上裕機

【緒言】膵頭十二指腸切除術 (PD) に対する術後管理の標準化は 難しい。当科では、安全な膵切除術の開発のための臨床試験を行 つてきたが、周術期管理においても特徴的な ERAS programを取 り入れたクリニカルパス (CP) の運用を行っている。今回、当科 での周術期管理による治療成績の検討を行った。【周術期管理】術 前管理: 術前禁煙指導、周術期強化リハビリの導入、術前腸管処 置の簡略化、術前日夕までの普通食摂取、術直前 2 時間前までの 経口水分摄取。術中管理：輸液制限、体温管理、硬膜外麻酔によ る鎮痛管理。術後管理：術直後の経鼻胃管抜去、早期経口摂取、 早期ドレーン抜去【対象】これらの項目から、胃管早期抜去 (no NG tube)、輸液制限、周術期強化リハビリの導入を検討した。【結 果】no NG tube；2009年 4 月から2014年12月にPD施行320例。胃 管再挿入率は20例 $(6.2 \%)$ D D GEによる再入院を 1 例 $(0.3 \%)$ に 認めたがDGEによる再手術は 0 例。輸液制限；2009年から2014年 にPD施行331例。輸液制限群で、膵液㾇、腹腔内膿瘍、腹腔内出血、 創部感染が有意に減少した。強化リハビリ導入；2003年から2014 年にPD施行576例。導入前後 (2009年以降) の 2 群を比較、呼吸 器合併症が有意に減少した。術後入院期間も有意に短縮した。【結 語】 PD患者において、ERASの概念を導入したCPと周術期リハ ビリの導入による厳重な周術期管理は、QOLの維持、合併症減少 に有用である。

PD19-1 消化器手術に対する強化血糖管理の文献的考察 と早期蛋白投与と持続インスリン静注併用による栄養管理の意 義 蘇生会総合病院 外科 土師誠二, 龟井武志, 野口耕右, 吉川徹二, 今西努

【目的】周術期血糖管理は重要であるが、対象術式、目標血糖值、 血糖管理期間、血糖管理方法、栄養投与量など、議論がある そこで、消化器外科手術に対する強化血糖管理の意義を文献的 考察から明らかにし、自験例をもとに臨床的意義について検討 した。【方法】(検討1. 強化血糖管理の文献的考察) 2000年 1 月 から2017年までに報告された消化器外科手術に対する RCTを 抽出し、術野感染症 (SSI) 、術後合併症、低血糖の発生率に対 してメ夕解析を行った。(検討2. 強化血糖管理の臨床的意義) 高度侵襲肝胆膵手術に対して、術後 7 日目まで目標血糖值を $150 \mathrm{mg} / \mathrm{dl}$ として持続インスリン静注を行い、同時に術後 3 日 目にエネルギー投与量 $20-25 \mathrm{kcal} / \mathrm{kg} /$ 日、蛋白投与量 $1.2 \mathrm{~g} / \mathrm{kg} /$ 日となるよう栄養管理を行った試験群38例を、目標血糖值を $180 \mathrm{mg} / \mathrm{dl}$ とした対照群63例と比較した。【結果】(検討 1 ) RCT4報に対してメ夕解析を実施、目標血糖值を 80- $110 \mathrm{~m} / \mathrm{dl}$ と した強化血糖管理で有意にSSI発生を抑制したが低血糖発生率 が高值であった。強化血糖管理では静脈栄養または経腸栄養が 実施されていた。(検討 2 ) 試験群では術後血糖值は $150 \mathrm{mg} / \mathrm{dl}$ 前後で推移、術後 7 日目までの血糖測定1000ポイントで低血糖 ( $660 \mathrm{mg} / \mathrm{dl})$ は 2 ポイントに発生した。試験群ではSSI発生率 は低かった。【結語】強化血糖管理は感染性合併症抑制に有効 であり、安全な実施には目標血糖值を $150 \mathrm{mg} / \mathrm{dl}$ とし栄養管理 との併用が重要であると思われた。 
下食道切除術後人工膵臓を用いた血糖管理法

高知大学医学部外科学講座外科 1

北川博之, 岩部純, 横田啓一郎, 前田将宏, 上村直, 宗景匡哉, 並川努, 花崎和弘

目的：食道癌に対する胸䐑鏡下食道切除術後、人工膵臓による 血糖管理法の有用性を術前糖尿病の有無別に検討する。対象と 方法：2009年 7 月から2018年10月に食道癌に対して胸䏶鏡下食 道切除術、胃管再建を施行した118例中、化学放射線治療歴の ある5例を除いた113例を対象とした。術前糖尿病の有無別に、 人工膵臓を用いて術後血糖値を $100-140 \mathrm{mg} / \mathrm{dl} に$ 管理した人工 膵臓群の背景因子 (年齢、性別、Stage、糖尿病の有無、BMI、 術前治療)、手術成綪 (手術時間、出血量)、術後合併症 (肺炎、 縫合不全)、在院日数を、sliding scale(SS) で $200 \mathrm{mg} / \mathrm{dl}$ 未満 で管理したSS群（人工膵臓群の採血不良を含む）と比較した。 結果：術前糖尿病21例、人工膵臓群99例、SS群14例だった。 術前糖尿病例に扔いて背景因子、手術成績は両群間で差を認め なかった。術後肺炎 (人工膵蔵群 $16.7 \%$ vs. SS群 $0 \%$; $\mathrm{p}=0.583$ ) に差を認めなかったが、縫合不全は人工膵臓群 (11.1\%) がSS 群 $(33.3 \%)$ より少ない傾向にあり $(\mathrm{p}=0.387)$ 、在院日数 $(19.5$ 日 vs. 30.0 日: $P=0.174 ＼mathrm{~ も 短 い 傾 问 て ゙ あ っ た 。 術 前 非 糖 尿 病 ~}$ 例では術後肺炎 (人工膵臓群 $11.1 \%$ vs. SS 群 $0 \%$; $p=0.244$ 、 縫合不全 (人工膵臓群 $14.8 \%$ vs. SS 群 $9.1 \%$; $\mathrm{p}=0.601$ )、在院日 数 (人工膵臓群 15 日 vs. SS 群 13 日; $\mathrm{p}=0.704$ ) ともに有意差を 認めなかった結語：胸挖鏡下食道切除術後、人丁膵臓に上る 血糖管理は、術前糖尿病症例において縫合不全が少ない傾向に あった。

PD19-3

食道癌における術前後における血糖と栄養のマ 园立国際医療研究センター外科

山田和彦, 齋藤範之, 榎本直記, 野原京子, 三田英明, 和氣仁美, 寺山仁祥, 加藤大貴, 片岡温子, 百瀬直也, 桑原麻衣, 堀越理仁, 清松知充, 竹村信行, 國土典宏

手術侵襲に伴う周術期における血糖管理に対しては, 1 重症患 者において高血糖の放置は有害. 2 強化インスリン療法には功 罪がある. 3 低血糖は予後不良因子. 4 指摘な血糖管理の值は 140-180mg/dlを目標. 5 血糖值の摇らぎは重要。6術後24時間 以内の血糖値も重要.さらに術前からの栄養サポートチーム (NST) の介入は必須である. 血糖の変動や持続モニタリング の重要性も指摘され, 人工膵臓療法は周術期のマニュアル状況 を一変させる 1 つ有用な方法と考え，高血糖症例に実施して いる.【対象と方法】2016年 6 月から2019年 5 月に当院で行わ れた食道手術で人工膵臓療法を行った70例を対象. 平均血糖値, 中央値, 血糖値変動, 目標血糖達成率, 周術期合併症と検討した 【結果】低血糖発作 $(<70 \mathrm{mg} / \mathrm{dL})$ はなく血糖値の摇らぎか 高いほど,目標達成率が低いほど呼吸器合併症の発生割合が有 意に高值であった $(\mathrm{p}<0.05)$. 糖尿病の既往がなくとも，血糖 コンロール不良な症例が存在する。ささ斿に, 全例に腸瘦を使用 しているが, 術前の栄養のマーカー以外にも抜去のタイミンク の1つとしてプレアルブミン値が有用であった【結語】血糖 のパラメーターと周術期合併症は関連がある。術前後における 血糖と栄養のマネジメシトが重要である。

PD19-4 膵切除後の耐糖能の変化

神戸大学肝胆膵外科

白川幸代, 外山博近, 石田潤, 寺井祥雄, 椋棒英世, 山下博成, 李東河, 清水貴, 朝倉悠, 蔵満薰, 小松昇平, 津川大介, 田中基文, 木戸正浩, 福本巧

【背景】膵切除後に血糖変化の詳細な検討は少ない。当院の症例で, 術前後の耐糖能, インスリン分泌能について検討した【対象と方 法】前向きコホート研究として行った。対象は膵頭十二指腸切除 (PD) 40例, 膵体尾部切除 (DP) 29例。術前と術後約 1 ケ月目（退 院前) に75g 経ロブドウ糖負荷試験 (OGTT) およびグルカゴン 負荷試験を行い，耐糖能とインスリン分泌能の変化を検討した インスリン分泌能の指標としてグルカゴ負荷試験から得られる $\Delta \mathrm{CPR}$ イインスリン抵抗性の指標としてHOMA-IRを用いた。 な 抢膵切除術直後は血糖は 4 検し、インスリンを用いて $200 \mathrm{mg} / \mathrm{dl}$ 以 下のコントロールを目標としている【結果】膵癌例はPD群40例 中12例 $(30 \%) 、 D P$ 群29例中 8 例 $(28 \%)$ であった。術前 OGTT で糖尿病 (DM) 型を示したのは膵癌 9 例 (45\%)、非膵癌 7 例 (14 $\%)$ で $(\mathrm{P}=0.01)$ 、術後の OGTTでは膵癌 6 例 $(30 \%)$ 、非膵癌 9 例 $(18 \%)$ と膵癌例でのみ DM例は減少した。術後の HOMA-IR の低下は PD, DP群ともに膵癌例で上り大きい傾向がみられた $(\mathrm{PD}-1.4$ vs $-0.5 \mathrm{P}=0.07, \mathrm{DP}-0.8$ vs $0.06 \mathrm{P}=0.05)$ 。また $\Delta \mathrm{CPR}$ $\mathrm{PD}, \mathrm{DP}$ 両群ともに術後に有意に低下した $(\mathrm{PD}: 3.0 \rightarrow 1.1 （ \mathrm{P}<$ $0.0001), \mathrm{DP}: 3.3 \rightarrow 1.8$ ( $\mathrm{P}<0.0001)$ 【考察】膵切除後にはインスリ ン分泌能は低下するが、膵癌症例では術後のDM改善例が少なく ない。膵癌では悪性腫瘍や膵炎の存在がインスリン抵抗性に関与 していると考えられ、周術期の血糖管理においても、疾患による 差異を認識する必要がある。

PD19-5

人工膵臓の導入から学ぶ周術期耐糖能障害の機

金沢大学 消化器 - 腫痬 - 再生外科 ${ }^{1}$, 富山県立中央病院 外 科 ${ }^{2)}$, 金沢医科大学 一般. 消化器外科 ${ }^{3}$, 高知大学 外科 14) 岡崎充善 1 ), 林泰寛 ${ }^{2}$, 田島秀浩 ${ }^{1}$, 蒲田亮介 ${ }^{1)}$, 大畠慶直 ${ }^{1}$,

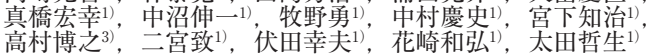

【背景】術後成績の改善と早期回復を目標として、周術期管理にお ける種々の丁夫が報告コれている。当科では周術期血糖管理目的 に人工膵臓を導入してきたが、糖代謝におけるサルコペ寻を含 めた患者因子との関連性について検討した。【方法】2014年 1 月よ り2017年 3 月まで当科で施行した膵頭十二指腸切除術症例 42 例、 2 区域以上の肝切除症例 54 例を対象とした。人工膵蔵を目標血糖 值80〜 110mg/dl とし手術開始時より24時間行った。24時間インス リン総投与量から低用量・高用量群に分け、患者背景について検 討した。サルコペニア評価項目として、腸腰筋指数 (PMI) - 筋肉 の脂肪化を表す IMAC・内臓脂肪面積と皮下脂肪面積の比である VSRを用いた。【結果】脺、肝切除症例において 24 時間インスリ ン総投与量は各々中央值83単位・75単位、目標血糖到達率は $31 \%$ 。 $24 \%$ であった。膵切除症例では高用量群で膵癌症例・BMI高值 · PMI 低值症例が有意に多く、肝切除症例では高用量群でサルコペ ニア評価項目 3 項自とも有意差を認めた。いずれの術式において も高用量群で目標血糖到達率は有意に不良であった。【考察】サル コペニアとインスリン抵抗性の関連が示唆されたが、骨格筋はイ ンスリン依存性のグルコース取り込みの場として重要な働きを有

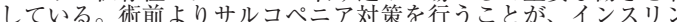
抵抗性の改善につながり、周術期の血糖管理の改善・術後合併症 軽減に寄与できるのではないかと考えた。

\section{PD19-6 \\ 肝移植周術期血糖管理における人工膵臓の有用}

長崎大学大学院 移植 $\cdot$ 消化器外科

曽山明彦, 釘山統太, 日高匡章, Pecquenard Florian, 夏田孔史, 濱田隆志，足立智彦，大野慎一郎，田中貴之，江口晋

の大きさは予後不良因子として報告されている。当科では、肝 移植周術期の血糖管理に人工膵臓を導入している。肝移植周術 期の血糖管理と術後細菌感染症の発症率低下に関する人工脺臓 の有用性を明らかにする目的で本研究を行った。【方法】1997 年から2019年 6 月までに当院で施行された肝移植298例のうち、 周術期血糖管理にClosed-loop 式人工膵臓（麻酔導入時から24 時間連続使用) を用いた 17 例 (目標血糖值 $100 \sim 110 \mathrm{mg} / \mathrm{dl}$ ) と 従来のスライディングスケール (SS) 法 (目標血糖值120 $180 \mathrm{mg} / \mathrm{dl}$ ）を用いた54例を対象として、周術期血糖值、術後 細菌感染発症率（細菌感染：培養陽性であり、関連する臨床症 状を認める症例）を比較した。【結果】平均血糖值は、人工脺 臓使用群がスライディングスケール群に比し、有意に低值を示 した $(118 \mathrm{mg} / \mathrm{dl}$ vs. $147 \mathrm{mg} / \mathrm{dl}, \mathrm{p}<0.01)$ 。両群において、 $50 \mathrm{mg} / \mathrm{dl}$ 未満となるような著明な低血糖は認めなった。術後30 日以内の細菌感染発症率は、人工膵蔵使用群がSS群に比し、 低い傾向にあった $(23.5 \%$ vs. $50.0 \%, \mathrm{p}=0.06)$ 。【考察】人工膵 臓は、肝移植周術期の安定した血糖管理を可能とし、関連して 術後細菌感染症の発症率低下につながる可能性がある。

肝細胞癌切除症例における術前 HbAlc と予後 および術後合併症

北海道大学 消化器外科学 I

島田慎吾, 神山俊哉, 折茂達也, 長津明久, 旭火華, 坂本譲, 蒲池浩文，武富紹信

【背景】近年、糖尿病罹患数の増加に伴い糖尿病を併存する肝細胞 癌 (HCC) 患者も増加している HbAlc と背景肝別の予後抢よひ 術後合併症について検討した。【方法】1997年から2014年までの初 回肝切除 HCC769例を対象とL.HbAlc 7 以上 $(\mathrm{Hi}-\mathrm{Alc}$ 群·n=89) 7 未満 (Lo-A1c 群; $\mathrm{n}=680)$ に群分けL、1) 全症例、背景肝別 に扮ける予後の比較、2) 非B韭C型 (NBNC) - Hi-Alc 群に抒 ける臨床病理学的特徽、3) 全症例に扮ける術後合併症との関連 について検討した。【結果】 NBNC225例、HBV304例、HCV255例 であった。1）5年全生存率（OS）は全体62\%、NBNC63\%、 HBV61\%、HCV59\% で有意差はなかった。 Hi-Alc 群、Lo-Alc 群 で 5 年 OS と無再発生存期間を比較すると NBNCでのみ $49 \% \mathrm{vs} 67 \%$ $(\mathrm{p}=0.01) 、 15$ 只 $\mathrm{vs} 26$ 只月 $(\mathrm{p}=0.04)$ と生存・再発ともに有意差 を認めたが、他の肝予備能、腫瘍因子を含めた多変量解析では有 意差を認めなかった。2） NBNC-Hi-Alc 群での背景肝別の臨床 病理学的特微はNBNC-L - A l c 群と比較し年齢、血小板で有意差 を認めたが、他の項目では同等であった。3) Clavien-Dindo3a 以上の術後合併症は $\mathrm{Hi}-\mathrm{Alc}$ 群 vsLo-Alc 群で高ビリルビン血症 $7.9 \% \mathrm{vs} 3.4 \%(\mathrm{p}=0.04) 、$ 肺炎 $6.7 \% \mathrm{vs} 1.6 \%(\mathrm{p}<0.01)$ 、創感染 $5.6 \% \mathrm{vs} 0.9 \%$ $(\mathrm{p}<0.01)$ であった。術後在院期間中央值は17日 vs16日と有意差 を認めなかった。【結語】HbA1c高值はNBNC-HCCにおいて独 肝切除後合併症のリスクファクターとなりうる。 
義 群馬大学 循環器外科

立石涉

心臓血管手術は多くの手術の中で侵襲が大きい部類の種類に入 り、炎症性サイトカインやインスリン拮抗ホルモンの上昇、組 織低酸素が起きやすい環境であるため、グルコース輸送体の夕 ウンレギュレーションからグルコースの取り込み障害が起きや すい状態にある。また、狭心症・動脈瘤・末梢血管疾患のよう な動脈硬化性病変を有する症例では、ベースに糖尿病を有して いることも多く、術後血糖コントロールに難渋する症例も多い。 術後高血糖が術後創部感染発症に悪影響を及ぼすことは周知の 事実であるが、心臓血管外科領域では術後創部感染・縦隔炎に より mortalityが著明に悪化するため確実な回避が必要である。 術後血糖管理の方法であるが、超急性期はCVIIによるコント ロール、食事開始後はスライディングスケール＋基礎インスリ ンなどのスケールがよいと考えている。基本的には高血糖回避 のみでなく低血糖回避を備えるスケールの作成が望ましい。 術後高血糖は術後創部感染のほかに、術後の発作性心房細動の 発症、㹂機能への影響、心不全への影響の可能性などが指摘さ れている。これらの内容について、我々の経験のデー夕を提示 し、さらに諸処の報告を考察して報告する。

PD20-1

早期胃癌に対しては腹腔鏡手術、進行胃癌に対 しては開腹手術

国立がん研究センター中央病院 胃外科

吉川貴己, 和田剛幸, 林勉, 大槻将, 山形幸徳, 片井均, 西田俊朗

Stage I胃癌に対する腹腔鏡手術のエビデンスは確立している。M/ L 胃癌に対しては、JCOG0912 phase III試験により、開腹幽門側 胃切除 (ODG) に対守る腹腔鏡下幽門側胃切除 (LDG) の非劣性 が検証されている。U 領域胃癌に対する腹胫鏡下の胃全摘 (TG) または噴門側胃切除 (PG) は、その安全性がJCOG1401により確 認されており、腫瘍学的安全性はJCOG0912試験が慨そうできる。 認されており、腫瘍学的安全性はJCOG0912試験が慨そうできる。 中国のCLASS-01 phase III試験結果がJAMAに報告された。 の試験は、M/L進行胃癌を対象に、開腹幽門側胃切除 (O群) に 対古る腹腔鏡下幽門側胃切除 (L群) のDFSにおりる非劣性を検 証している。1056例が登録（528例ずつL群とO群）された。同意 撤回と術中非切除を除外したL群519例とO群520例の 3 年DFSは、 それぞれ76.5\%、77.8\%であり差は-1.3\%であった。95\% CI下限 は設定したー10\%を大きく上回っており、非劣性は検証されなか った。ほほ同様の KLASS-02試験結果も、6月のIGCCで発表さ れたが主解析で非劣性は証明されなかった。両試験ともに Compliance/Conversion/同意撤回の点で質は低く、出血量の点で手術 の質も低い。「大網切除」についての規定もない。現時点で、本邦 で「推奨できる」とは言い難い。また、上部のStage II-III 進行胃 癌に対しては、「大網問題」に加え、大弯病変への「脾摘問題」が 加わる。現時点では、Phase III試験結果もない。

PD20-2 腹腔鏡下胃切除は胃癌に対する標準手術になり

得るのか

大阪赤十字病院 消化器外科

念点研有明病院 消化器外科

佐野武

進行胃癌に対して腹䏶鏡下切除 $(\mathrm{LG})$ が広く普及することの 懸念を、（A）長年の歴史で出来上がった開腹胃癌手術（OG） の質が落ちないか? (B) 腹腔鏡手術が、手段ではなく目的と ならないか? という2点について述べる。[A-1] OGでは 開腹後にまず腹膜播種、横隔膜下の肝転移の有無、Kocher 授 動によるNo.16リシパ節の触診、などで広く腹腔内等の腫瘍の進 展を探る。これがLGで十分できるか？[A-2] 触診による腫 瘍の胃壁内進展、十二指腸・食道への進展、リンパ節転移診断 が、LGでできるか? 腫湯から十分距離をおいた切離線を決定 できるか？[A-3］腫瘍に対する愛護的操作（つつかない 掴まない、挟まない、など）がLGでできるか? [A-4] 閉腹 前に、（術中散布した可能性のある癌細胞を洗い出す目的で） 腹腔内を十分洗浄できるか? [A-5] (以上の結果として) OG と同様の腫瘍局所制御が達成できるか?子宮頸癌に対する 米国の RCTで示されたような局所再発の増加がなければよい が、と心配方る。[B-1] 術式(切除範囲、再建方法、郭清範囲、 試験サンプリングなど）の決定に際し、「癌の手術としてべス トたから」ではなく「LGに都合がよいから」が主たる要素に ならないか? [B-2] 予想外の出血や困難な状況に遭遇した 場合、LGを完遂しょうとして、不十分な（あるいは危険な） 切除にならないか? 杞憂であることを願うのみである。

\section{PD20-基調講演}

静岡がんセン多ー 胃外科 寺島雅典

腹腔鏡下胃切除術（LG）は胃癌に対する低侵襲手術として広 く普及しているが、2010年以前には明確なエビデンスは存在せ ず、ガイドライン第 3 版 (2010) では早期胃癌に対する研究的 治療と位置づけられている。日本臨床腫瘍研究グループ (JCOG) ではLGのエビデンスを確立するために、cStage I 胃 癌に対する腹腔鏡下幽門側胃切除術 (LDG) の安全性を検討 する第II相試験 (0703) を行つた。その結果、primary end pointである縫合不全、膵液漏の発生率は極めて低率であり帰 無仮説は菓却された。続いてLDGの開腹胃切除術 (ODG) に 対する非劣性を検証する第III相試験 (0912) が行われた。Primary endpointである無再発生存率は両群で差を認めず、統計 学的に非劣性が証明された。また、腹腔鏡下勇全摘術 (LTG)。 噴門側胃切除術（LPG）の安全性を検討する単アームの検証的 第 III 相試験 (1401) も行われ、LTG、LPGの安全性が確認さ れた。進行胃癌に関しては我が国（JLSSG0901）、韓国 (KLASS-02)、中国（CLASS-01）でLDGの ODGに対する非 劣性を検証する第III相試験が行われている。CLASS-01の結 果は既に公表されており、LDGのODGに対する非劣性が証明 されている。進行胃癌に対するTGに関しては韓国で第III相 試験が進行中であるが、JCOGでは脾門郭清の安全性を検討す る第II相試験（1809）が進行中である。
金谷誠一郎, 細木久裕, 八木大介, 坂口正純, 所為然

【はじめに】当科では，一部の拡大郭清を要する症例を除き， 基本すずての胃癌に腹腔鏡下胃切除を行っている、今回，当 科での成績から, 腹腔鏡下幽門側胃切除 (LDG: laparoscopic distal gastrectomy), 腹腔鏡下胃全摘 (LTG: laparoscopic total gastrectomy) が胃癌に対する標準手術になり得るか検討 を行った【対象と方法】2011年 4 月から2019年 3 月の期間に 当科で胃癌に対しLDGあるいはLTGを施行した患者779例の 短期および長期成績を解析した。【結果】 LDG 570例, LTG209 例。技術認定医の施行はLDG，LTGでそれぞれ189例 $(33.2 \%)$ 142 例 $(67.9 \%)$ 。手術時間は268分と355分. 出血量はどちらも 少量 $(\fallingdotseq 0)$, 術後在院日数は12日と13日であった。リンパ節 郭清の D1+以下：D2以上は, LDGで319:252, LTGで131:78で, 559例 (97.7\%) 193例（92.3\%）でR0手術が施行された. Clavien-Dindo Grade III 以上の術後合併症は, 13例（2.3\%）14例 $(6.7 \%)$ で涩められ，膵液瘦は 3 例 $(0.5 \%) 0$ 例, 縫合不全は 5 例 $(0.9 \%) 3$ 例 $(1.4 \%)$ であ つ た. pStage IA:IB:IIA:IIB:IIIA:IIIB:IIIC:IV は，345:114:84:70:58:54:35:29例で, 5 年生存率はそれぞれ92.9:96.5:90.4:90.1:56.9:57.9:53.0:48.9\%であ つた、まとめ】当科の成績から LDGと LTGの安全性, 根治 性に問題はなく, 胃癌に対亦る標準手術になり得るもの之考え られた。たたし, 単施設少数例での成績であり,より多数から 長期のエビデンスの蓄積が必要である。

PD21-1進行大腸癌に対する腹腔鏡下手術の臨床試験か らわかる最新のエビデンス 大分大大学 消化器. 小览外科 ${ }^{11}$, 大分大学地域医療学センター 外科分野 ${ }^{2}$

赤木智徳 1 ，河野洋平 1） 平塚孝宏1) 鈴木浩輔 1) 柴田智隆 1) 上田貴威 ${ }^{2}$, 當寺ヶ盛学 ${ }^{12}$, 白下英史 ${ }^{1)}$, 衛藤剛 1 , , 白石憲男 ${ }^{2}$, 猪股雅史 ${ }^{1}$

【はじめに】本邦では大腸癌に対して腹腔鏡下手術（LAP）の 普及率は年々増加しており、進行癌に対してもLAPが施行さ れている。新規治療法の開発普及には、質の高い臨床研究 （RCT）の結果に裏打ちされる必要がある。進行大腸癌に対す る腹腔鏡下大腸切除術の癌の根治性に関する評価は、日本臨床 腫瘍研究グループの多施設共同研究 JCOG0404 (stageII/II) と して施行し、JCOG1107 (stage IV) は症例登録中である。現 在す守めている subgroup 解析を中心に報告する。【結果】 JCOG0404について：5 年全生存率は開腹手術（OP）、LAP それぞれ 90.4\%、91.8\% であり、LAPの OPに対する非劣性は 証明できなかった。しかしLAPはOP と比べ在院日数が短く、 創関連合併症が少なかった。Subgroup解析にて肥満症例に対 してLAPは予後に悪影響を及ほす可能性が示唆された。 JCOG1107について：2019年 8 月時点で $85 \%$ (予定登録数294 例）の登録が完了し年内に登録完了予定。【結語】進行大腸癌 へのLAPは短期成績より熟練した外科医により安全に施行で きることが示され、長期成績においては進行大腸癌に対する LAPは acceptable optional treatment と考えられた。今後は subgroup解析結果、JCOG1107の解析結果を正しく解釈し、臨 床現場に還元していく必要がある。 
PD21-2 標準手術としての腹腔鏡下大腸切除術の位置つ 埼玉医大国際医療センター 消化器外科 山口茂樹

腹腔鏡手術と開腹手術を比較した臨床試験やレビューは数多く 行われてきた。結腸癌においては無作為比較試験で腹腔鏡手術 の低侵襲性と長期成績の非劣性が示されてきたが、唯一我が国 で行われたJCOG0404では非劣性が示されなかった。それは想 定上り瑤かに高い生存率が得られたことによるイベント不足が 原因と考えられている。また横行結腸癌はすべての試験から除 外されていたが、我が国の多施設の後ろ向き検討からはほぼ同 等との結果が得られた。直腸癌における無作為試験では諸外国 から非劣性が示された二方、直腸剥離面での癌陽性率が腹腔鏡 手術に高いという結果もみられ奬念が残るのも事実である。腹 腔鏡手術の技術はその浸透率の上昇とともに上がってきてお り、多くの施設で日常的に行われるようになった。多くの大腸 癌根治手術が腹腔鏡の利用によって早期回復が得られるメリッ 卜は大きい。二方、直腸進行癌や大きな結腸癌、癒着や肥満症 例に関してはある程度の技術と癌に対する配慮を伴う手術が必 要である。術式選択は術者の技量に応じるものではあるが、胆 囊摘出術と同様に大腸切除も腹腔鏡手術割合が増加すると考え る。

PD21-3 横行・下行結腸癌に対する開腹と腹腔鏡手術の ランダム化比較試験

横浜市立大学附属市民総合医療センター 消化器病セン夕 -1 , 横浜市立大学 消化器・腫瘍外科学 2 , 横浜国立医療セン 夕一外科 ${ }^{3)}$, 横須賀共済病院 外科 ${ }^{4}$, 横浜市立みなと赤十字 病院 外科 ${ }^{5}$, 甲賀病院 外科 6 )

諏訪雄亮 11 , 渡邊純 ${ }^{1)}$, 後藤晃紀 ${ }^{1)}$, 鈴木紳祐 ${ }^{2}$, 中川和也 ${ }^{3)}$,

諏訪宏和 ${ }^{4}$, 石部敦士 ${ }^{2)}$, 武田和永 ${ }^{1)}$, 大田貢由 ${ }^{5)}$, 藤井正一 ${ }^{6)}$,

國崎主税 1 , , 遠藤格 2 ?

【背景】横行/下行結腸癌に対する腹腔鏡手術の安全性,および長期予 後に関しての十分なエビデンスはない【目的】横行/卡行結腸癌に対 多る腹沿鏡手術の短期及び長期成績を検討古る【方法】横行/下行結 腸癌に対して腹腔鏡手術と開腹手術のランダム化比較試験を行い短 腸癌に対して腹腔鏡手術と開腹手術のランダム化比較試験を行い短

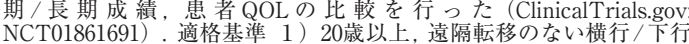
結腸癌，3）腫瘍短径 $8 \mathrm{~cm}$ 未満とした。 66 例を登録し術前に開腹/腹胺 鏡に各33例にランダム化した。腹哚鏡手術は日本内視鏡外科学会技術 認定医が施行し，中枢郭清を伴ったCMEを施行し両群の短期/長期成 績を比較検討した.【結果】患者背景に有意差なし, 平均追跡期間は71 ケ月であった pStage0-I/II/III, 腹腕鏡群: $21 / 7 / 5$ 例, 開腹群: 11/14/8例であった。手術時間は腹腔鏡群179分，開腹群142分 $(\mathrm{p}=$ 11/14/8 例であった。手術時間は腹胿鏡群179分,開腹群142分 $(\mathrm{p}=$ 後合併症は6.2. $12.1 \%(\mathrm{p}=0.392)$ 術後在院日数は両群 8 日 $(\mathrm{p}=0.625)$ であった。 5 年RFS は90.5\%, 87.3\% ( $\%(\mathrm{p}=0.543)$ であった. 患者QOL $1 / 6$ か月後ともに社会活動制限 や精神的苦痛は腹腔鏡群の方が良好であった。結語】横行/下行結腸 癌に対して腹腔鏡手術は開腹と比較し短期/長期成績において同等で あり、患者のQOL は良好であったため腹腔鏡手術が推められる。

PD21-4 ビッグデータ（DPC/PDPS）を用いた Stage IV 結腸癌に対する手術成績の検討（短期手術成績について） 産業医科大学 消化器. 分分泌外科 11 , 産業医科大学若松病院 外科 ${ }^{2}$, 産業医科大学 環境疫学 ${ }^{3}$, 産業医科大学 公衆衛生学 ${ }^{4)}$ 永田淳 ${ }^{1)}$, 藤野善久 ${ }^{3)}$, 田嶋健秀 1 ), 秋山泰樹 1 , , 川北康貴 ${ }^{1)}$, 鳥越貴行 1 , 藤本賢治 ${ }^{3)}$, 荒瀬光二 2 , , 秋山正樹 2 , 矢吹慶 2 , 沢津橋佑典 ${ }^{12}$, 田上貴行 ${ }^{1)}$, 松田晋哉 4 , 平田敬治 ${ }^{1)}$

【背景 Diagnosis Procedure Combination/Per-Diem Payment System(DPC/PDPS) は急性期入院を対象とする診断群分類に基 ゔく1日あたり包括払い制度であり、参加病院は全国1,730病院/ 49万床にのほる。この制度で集約されたビッグデータを用いて、 いわゆる real world でのStage IV 結腸癌における解析を行い、新 たな知見を得た。【対象および方法】2014年 4 月から2016年 3 月ま

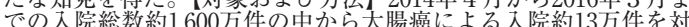
象とした。デー夕は研究使用への同意を得たものを用いた。解析 に必要な変数の欠損例を除く77,542例の結腸癌が解析対象となっ た。マルチレベル解析を用いて後方視的に分析した。【結果】解析 可能な77,542例の結腸癌患者に手術が施行された。Stage IVは8,124 例 (全結腸癌手術の10\%) であった 4,795例 (59.02\%) が開腹群、 3.329 例 $(40.98 \%)$ に腹腔鏡下群であった197例 $(2.42 \%)$ に全 身麻酔をともなう再手術が施行された。334例 (4.11\%) に術後七 日以内の輸血が投与されていた。 BMIが18を下回る症例は873例 $(10.75 \%)$ であり、他のStageに比べ多い傾向が見られた。術後30 日以内の在院死亡は106例 (1.3\%) に認められStage1-3より多い 傾向がみられた。【結論】短期の手術成績において Stage IV 結腸 癌がいくつかの特徴をもつことが real worldのデータとして示さ れた。 術の妥当性に関する第II相試験（Lap RC）の最終成績 東海大学 消化器外科1 1 , 北里研究所病院 ${ }^{2}$

山本聖一郎 ${ }^{1)}$, 渡邊昌彦 2 ,

（目的） clinical Stage 0-I期直腸癌に対して、腹腔鏡手術の妥 当性を検討する多施設共同前向き試験（検証的phase II 試験) を行った。周術期成績は開腹手術と比較して許容できる成績て あった。本試験の最終成績を報告する。(対象と方法) 局所切 除術の適応とならない,または内視鏡切除を含む局所切除術後 に根治術が必要と判断される術前診断 c-Stage 0-Iの,腫瘍主 占居部位が Ra,Rbの直腸癌患者を対象として、腸管切除、リン パ節郭清をともなう腹腔鏡下手術の安全性の評価を目的とし た primary endpoint は全生存期間、secondary endpoints 無再発生存期間、手術成績であった。登録基準は年嚙25-75歳、 cStage0/I、腫瘍径 cm 以下、前治療なし、腸閉塞なしとした。（結 果）2008年から2010年の間に、全国43施設から登録された495 症例のうち適格症例は490例であった。全商格例の 5 年全生存 率は96.6\% (95\%CI 94.6\%-97.9\%)、5 年無増悪生存率は90.1\%

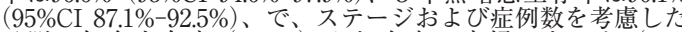
予測 5 年全生存率 (81.1\%) より有意に良好であった（p< 0.0001)。(結語) clinical Stage 0-I期直腸癌に対しては腹䏶鏡 手術は標準手術となりうる。今後は進行直腸癌で検証的臨床試 験を行うか考えていく必要がある。

PD21-6 専門施設では腹腔鏡下手術が直腸癌に対する標

準治療である

京都大学消化管外科 1 ，，腹腔鏡下大腸切除研究会2)

肥田侯矢 ${ }^{1,2)}$, 西崎大輔1,2) , 住井敦彦1,2) , 小西毅 2) , 赤木智徳2) 山口智弘 ${ }^{2}$, 秋吉高志 ${ }^{2}$, 福田明輝 ${ }^{2)}$, 岡村亮輔 ${ }^{1,2}$, , 山本聖一郎 ${ }^{2}$, 坂井義治 ${ }^{1,2}$, , 渡邊昌彦 2

【背景】

直腸癌に対する腹腔鏡手術の有用性については海外のランダム化比較試 験でも結論が出ていない。本邦に扔ける多施設共同観察研究の結果は、短 期成績において下部進行直腸癌に対する腹腔鏡下手術は開腹手術を上回 る成績であり、長期成績においても、開腹手術との差は見られていない。 【研究の概要】

参加施設】腹腔鏡下大腸切除研究会に参加の69施設

【対象】2010年から2011年に手術の行われたcStage II-IIIで、腹膜翻転部 以下に腫瘍下縁が位置するもの (Rbを含む腫瘍)、他癌の合併や緊急症例 を除外

【術者】全員が50例以上の開腹大腸癌手術の経験、 $97 \%$ か 30 例以上の腹堎 鏡下大腸癌手術の経験をもち、開腹および腹膛鏡のいずれも100例以上の 経験を有していた術者は $86 \%$

【結果】集積された症例数は1608例で、108例を除外して1500例の解析を 行った。術前因子による傾向スコアマッチングで開腹・腹腔鏡それぞれ 482 例ずつの症例を比較。術前治療は $35 \%$ に行われており、開腹移行率は $5.2 \%$ で、術中出血量 (開腹 $625 \mathrm{ml}$ 、腹䏕鏡 $90 \mathrm{ml}$ )、グレード 2 以上の術後 合併症(開腹 $39.3 \%$ 、腹腕鏡 $30.3 \%$ ) はいずれも有意差を認めた。長期予 後については、追跡期間中央値 5.0 年で 5 年無再発生存率は開腹 $65.0 \%$ 、腹 後については、追跡期間中央值 5.0 年で 5 年無

腔鏡63.

以上の結果より、本邦の専門施設においては、直腸癌に対する腹腔鏡下

手術は標準治療と考えてよいと思われる。

PD21-7＜wide>腹腔鏡下手術の開腹手術に対する優越性を考え 東京女子医科大学 消化器 - 一般外科 ${ }^{1)}$, 東京女子医科大学 乳腺内分泌外科

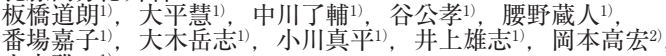
山本雅一1

国内外の大規模ランダム化比較試験により結腸癌に対する腹腔鏡 下手術 (LS) は開腹手術 (OS) に比べて短期成綪が優れている ことが報告されている。長期成績も再発率や生存率が同等である との報告があるが、本邦で行われたJCOG0404ではプライマリエ シドポイシトである全生存期間でLSのOSに対する非劣勢は証明 することができなかった。両群の治療成績は極めて良好で実臨床 では acceptableな結果であるが、直に劣勢を有する可能性があり 注意して症例を重ねる必要がある。特にT4、N2症例でLSの予後 が不良である傾向が指摘されている。

臨床試験の結果から考察する場合に問題となるのが、多くの臨床 試験では横行結腸が除外されていることである。解剖学的な血管 の走行を理解した郭清の難度が高いのが原因である。未た、多く の学会で横行結腸に対するLSの手技が度々取り上げられているこ とからも容易に推察できる。

直腸癌についても結腸癌と同様に前向き臨床試験が行われてお り、長期予後の非劣勢が報告されている。しかしながら、欧米て は術前化学放射線療法が一般的であることや本邦では側方りンパ 節郭清を行っていることなど、アプローチ方法に相違があること に注意が必要で、一概に外抻守ることは困難である 自施設の臨床成績を臨床試験の結果と比較しながら考察を加え 